\title{
BIOLOGIA E FUSÃO DE PROTOPLASTOS DE LEVEDURAS FLOCULANTES E $\mathrm{H}_{2} \mathrm{~S}^{-}$
}

CLEIDE VIVIANE BUZANELLO MARTINS

Bióloga

Orientador: Prof. Dr. JORGE HORII

Dissertação apresentada à Escola Superior de Agricultura "Luiz de Queiroz", Universidade de São Paulo, para obtenção do título de Mestre em Agronomia, Área de Concentração: Microbiologia Agrícola.

PIRACICABA

Estado de São Paulo - Brasil

Agosto - 1997 
Dados internacionais de Catalogação na Publicação (CIP)

DIVISÃO DE BIBLIOTECA E DOCUMENTAÇĀO - Campus "Luiz de Queiroz"/USP

Martins, Cleide Viviane Buzanello

Biologia e fusão de protoplastos de leveduras floculantes e $\mathrm{H}_{2} \mathrm{~S}$ / Cleide Viviane Buzanello Martins. - - Piracicaba, 1997.

95 p. : il.

Dissertação (mestrado) - Escola Superior de Agricultura Luiz de Queiroz, 1997.

Bibliografia.

1. Fusão de protoplasto 2. Genética 3. Levedura 4. Marcador molecular 5.

Microbiologia industrial I. Titulo

CDD 589.23

660.2 


\title{
BIOLOGIA E FUSÃO DE PROTOPLASTOS DE LEVEDURAS FLOCULANTES E $\mathrm{H}_{2} \mathrm{~S}^{-}$
}

\author{
CLEIDE VIVIANE BUZANELLO MARTINS
}

Aprovada em: 01.10.1997

Comissão julgadora:

Prof. Dr. Jorge Horii

ESALQ/USP

Prof . Dra. Aline Aparecida Pizzirani-Kleiner

ESALQ/USP

Prof. Dra. Lilian Amorin

ESALQ/USP

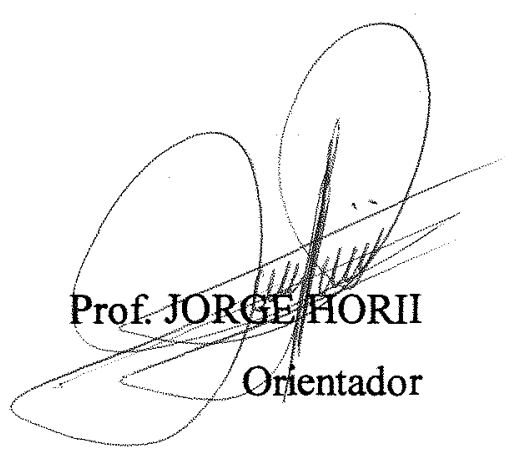


A Ricardo e Thaline, pelo amor, compreensão, incentivo e apoio

Aos meus pais, Heitor e Diomira, pelo amor e incentivo

DEDICO 


\section{AGRADECIMENTOS}

- Ao Prof. Dr. Jorge Horii pela oportunidade, orientação durante a realização deste trabalho, apoio, respaldo e compreensão.

- À Prof ${ }^{\circledR}$ Aline Aparecida Pizzirani-Kleiner, pela amizade, valiosas contribuições e concessão do Laboratório de Genética de Fungos Filamentosos da ESALQ/USP, onde foi possível a realização deste trabalho.

- À amiga Chirlei Glienke, pela amizade, constantes orientações e sugestões.

- Ao colega Luiz Humberto Gomes pelas valiosas orientações durante a execução deste trabalho.

-Ao amigo Walter Maccheroni Júnior pelas sugéstões, incentivo e em especial pelo apoio na elaboração do Summary.

- À Margarete Nadalini pelas sugestões e por me incentivar na obtenção dos mutantes.

- Aos amigos Carlos e Gisele Vildoso pela amizade, sugestões e incentivo. 
- Aos amigos Robertinho (Roberto Serpa Dias), Maria da Piedade Araújo, Patrízia Raji Abdala, Mônica Rosa Bertão, Marcos e Cássia Montoya, pela amizade e pelos bons momentos convividos.

- Aos amigos Márcia Roncato, Fabiana Siqueira e Samuel Gislon Silva.

- Aos colegas de laboratório Welington Luiz de Araújo, Rosemeire Bueno, Gilda Mühlen, André Lima, Joelma Marcon, Derlene Atili, Zezo e Cris.

- Ao colega Carlos Ribeiro pelo convívio e concessão da linhagem $\mathrm{H}_{2} \mathrm{~S}^{-}$

- Ao colega Carlos Eduardo Garcia pelo auxilio na tentativa de identificar as linhagens, e pela liofilização das linhagens obtidas.

- À CAPES pela concessão da bolsa de estudos.

- A todos os professores que contribuíram para a minha formação cientifica, e às demais pessoas que direta ou indiretamente auxiliaram na execução deste trabalho. 


\section{SUMÁRIO}

Página

LISTA DE FIGURAS............................................................................

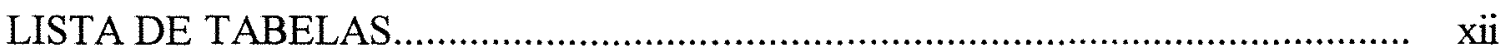

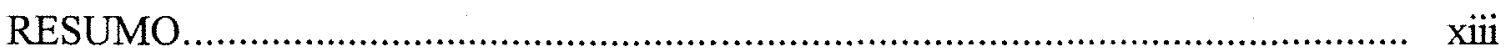

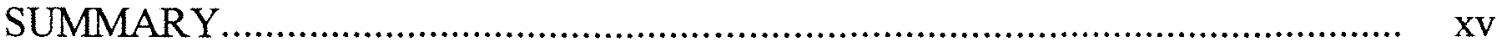

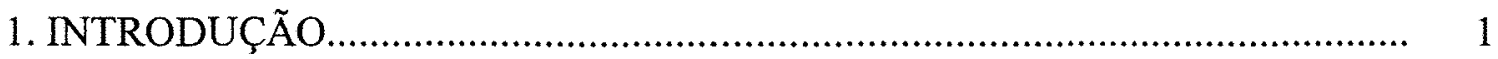

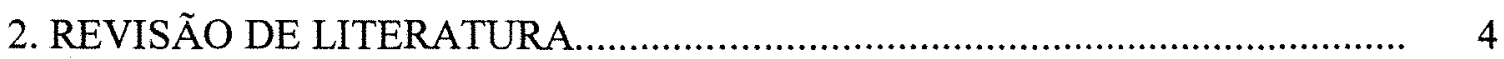

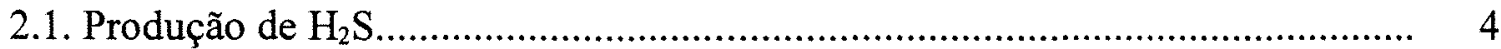

2.1.1. Sulfeto de hidrogênio e bebidas fermentadas............................................. 5

2.1.2. Mecanismo de produção de $\mathrm{H}_{2} \mathrm{~S}$........................................................ 7

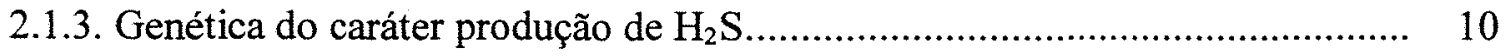

2.1.4. Formação de $\mathrm{H}_{2} \mathrm{~S}$ por desaminação proteolítica........................................ 13

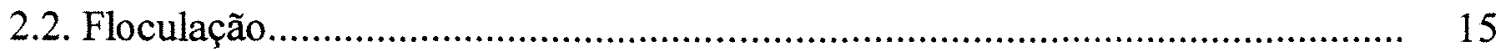

2.2.1. Tipos de agregação celular.............................................................. 16

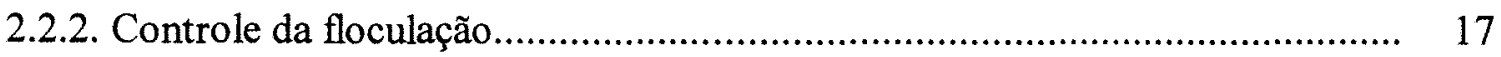

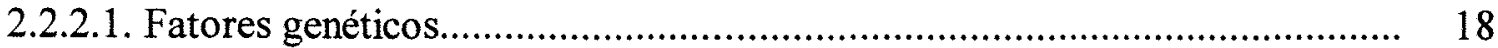

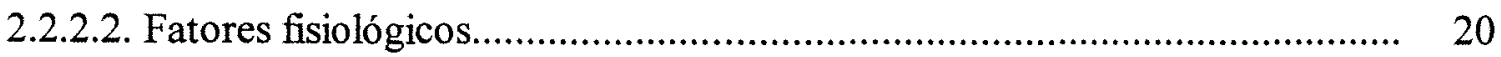

2.2.2.3. Fatores ambientais.................................................................... 22

2.2.3. Teorias moleculares da floculação.......................................................... 23

2.3. Fusão de protoplastos em leveduras....................................................... 24

2.4. Técnicas Moleculares....................................................................... 27

2.4.1. Eletroforese de campo pulsado - (Pulsed-Field Gel Electrophoresis)............. 27 
2.4.2. Polimorfismo do DNA amplificado ao acaso - (Random Amplified Polimorrphic DNA - RAPD).................................................................. $\quad 30$

3. MATERIAL E MÉTODOS................................................................ 34

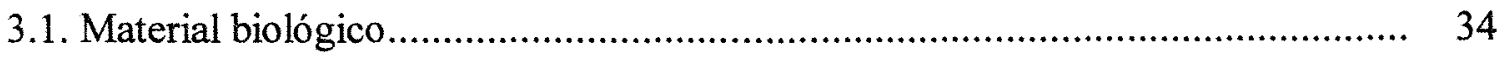

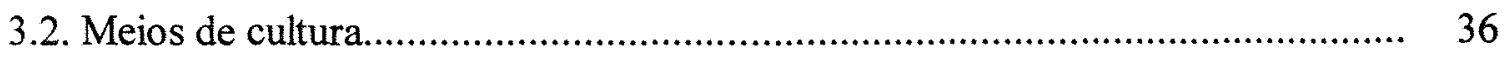

3.2.1. Meio YEPD (Mortimer \& Hawthorne, 1969)............................................. 36

3.2.2. Meio mínimo (Reaume \& Tatum, modificado por Fungaro \& Pizzirani-

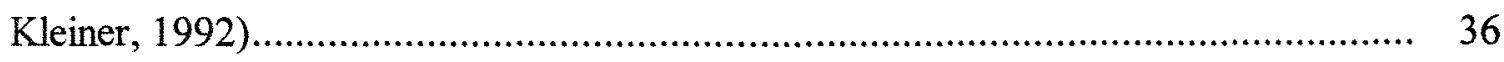

3.2.3. Meio BSA (Bismuth sulfite agar desidratado - DIFCO)................................. 37

3.2.4. Meio YEPD de regeneração...................................................................... 37

3.2.5. Meio mínimo de regeneração.............................................................. 37

3.2.6. Meio de esporulação - rafinose acetato (RA) ................................................. 38

3.3. Soluções e Tampões............................................................................ 38

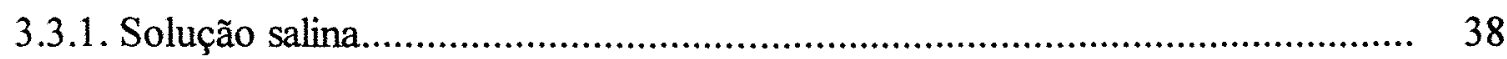

3.3.2. Solução de vitaminas........................................................................... 38

3.3.3. Solução de ácidos nucléicos de leveduras..................................................... 39

3.3.4. Solução de caseína hidrolisada .................................................................. 39

3.3.5. Solução de requesitos nutricionais............................................................ 39

3.3.6. Solução tampão fosfato sorbitol (TSP $1 \mathrm{M}$ )................................................. 40

3.3.7. Solução de EDTA $10 \mathrm{mM}$....................................................................... 40

3.3.8. Solução enzimática para obtenção de protoplastos........................................... 41

3.3.9. Solução de cloreto de cálcio $(1,2 \mathrm{M})$............................................................. 41

3.3.10. Solução fusogênica (PEG 40\%).......................................................... 41

3.3.11. Agarose LGT (low gelling temperature) - 1,4\%.................................. 41

3.3.12. Tampão NDS.................................................................................... 41

3.3.13. Agarose para Pulsed -Field 1\% (Sigma A)................................................. 42

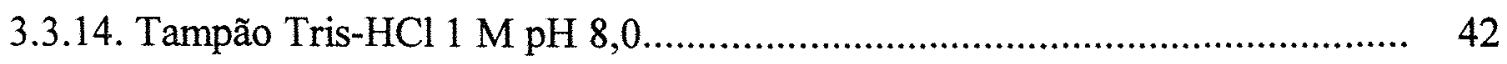

3.3.15. Tampão de corrida TBE 10X concentrado................................................ 42

3.3.16. Solução de EDTA 0,05 M pH 8,0......................................................... 43

3.3.17. Solução estoque de brometo de etídio.......................................................... 43 


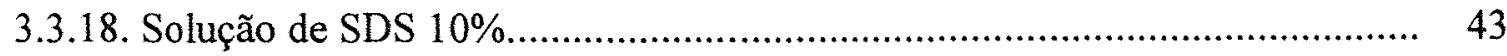

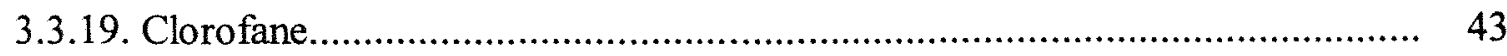

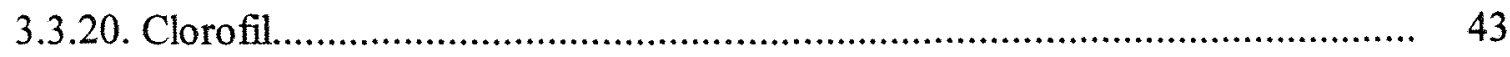

3.3.21. Solução de acetato de sódio $3 \mathrm{M} \mathrm{pH} \mathrm{4,8 \ldots \ldots .............................................} 43$

3.3.22. Tampão TE (Tris-EDTA)................................................................ 44

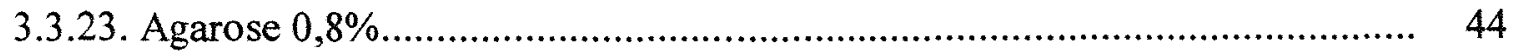

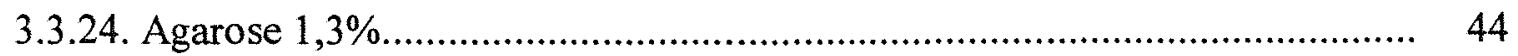

3.4. Teste de potencial para produção de $\mathrm{H}_{2} \mathrm{~S}$....................................................... 44

3.5. Teste de floculação............................................................................................ 45

3.6. Curva de sobrevivência à luz ultravioleta......................................................... 45

3.7. Obtenção de mutantes auxotróficos........................................................... 46

3.8. Caracterização dos mutantes auxotróficos........................................................ 47

3.9. Teste de reversão................................................................................ 47

3.10. Curva de crescimento em meio YEPD..................................................... 48

3.11. Obtenção de protoplastos............................................................................. 49

3.12. Regeneração de protoplastos.................................................................... 50

3.13. Fusão de protoplastos............................................................................ 50

3.14. Teste de estabilidade dos produtos de fusão.................................................. 51

3.15. Técnicas moleculares.......................................................................... 52

3.15.1. Eletroforese de campo pulsado - Pulsed-Field - para separação de DNA cromossômico de leveduras......................................................................... 52

3.15.1.1. Estimativa do peso molecular de bandas cromossômicas............................ 53

3.15.2. Polimorfismo de DNA amplificado ao acaso - RAPD (Random Amplified Polimorphic DNA) ............................................................................... 53

3.15.2.1. Isolamento de DNA de leveduras para RAPD......................................... 54

3.15.2.2. Quantificação e análise da integridade do DNA ……................................. 55

3.15.2.3. Construção de dendrogramas.................................................................. 55

4. RESULTADOS E DISCUSSÃO................................................................. 57

4.1. Obtenção de mutantes auxotróficos.................................................................. 57

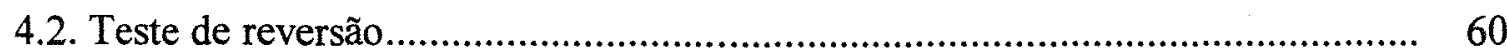




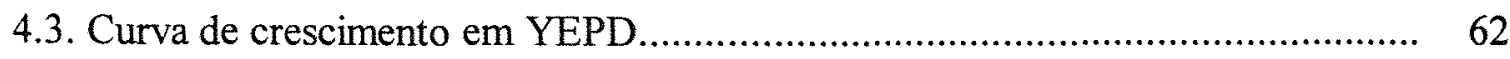

4.4. Obtenção e regeneração de protoplastos......................................................... 63

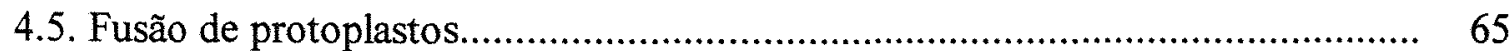

4.6. Separação de DNA cromossômico em leveduras - Pulsed-Field......................... 68

4.7. Polimorfismo de DNA amplificado ao acaso - RAPD ....................................... 73

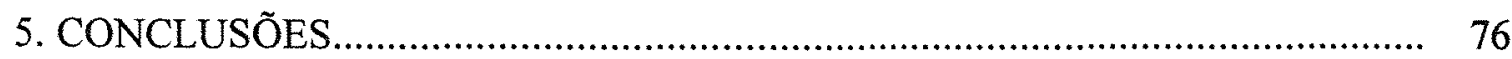

REFERÊNCIAS BIBLIOGRÁFICAS............................................................ 77 


\section{LISTA DE FIGURAS}

Página

1 Via de assimilação do sulfato, biossíntese da metionina e cisteína e a interrelação com a produção de sulfeto de hidrogênio. (Adaptado de Wainwright, 1971; Vine, 1993; Haecht \& Dufour, 1995).............................................

2 Genes envolvidos na via metabólica do sulfato em Saccharomyces cerevisiae. MET2: homoserina acetiltransferase; MET3: ATP sulfurilase; MET6: homocisteína metiltransferase; MET10: sulfito redutase; MET14: APS quinase; MET25: O-acetilhomoserina e O-acetilserina sulfidrase; NHS5: cistationina $\beta$-sintetase (Hammond, 1995).

3 Mecanismo de desenvolvimento de $\mathrm{H}_{2} \mathrm{~S}$ durante a fermentação em mostos deficientes em nitrogênio assimilável (Vos \& Gray, 1979).

4 Controle direto ou indireto da floculação de microrganismos (Atkinson \& Daoud, adaptado por Bromberg, 1994)

5 Linhagem ABXR.11B: flóculo formado pela agregação de milhares de células, quando cultivadas em meio YEPD. (Aumento 400X)

6 Linhagem IZ 987: características celulares, quando cultivadas em meio YEPD. (Aumento 400X)

7 Leveduras em meio BSA, após 24 horas de cultivo: (A) linhagem $\mathrm{H}_{2} \mathrm{~S}^{+}$; (B) linhagem $\mathrm{H}_{2} \mathrm{~S}^{-}$

8 Curva de sobrevivência da linhagem ABXR.11B de Saccharomyces cerevisiae à luz ultravioleta. 
9 Curva de crescimento das linhagens ABXR.11B e IZ 987 em meio YEPD (média de 3 repetições)

10 Protoplastos obtidos a partir de células da linhagem ABXR.11B após $60 \mathrm{~min}$ de exposição à enzima Novozym 234 (Aumento 1000X - imersão).

11 Resolução de bandas cromossômicas das linhagens parentais, dos produtos de fusão e dos segregantes. (a) padrão de Saccharomyces cerevisiae; (b) ABXR.11B; (c) IZ 987; (d) PF67; (e) 26S; (f) 15S; (g) 18S; (h) PF70

12 Diagrama da resolução das banda cromossômicas das linhagens parentais, dos produtos de fusão e dos segregantes. (a) padrão de Saccharomyces cerevisiae; (b) ABXR.11B; (c) IZ 987; (d) PF67; (e) 26S; (f) 15S; (g) 18S; (h) PF70.

13 Padrão de amplificação de fragmentos de DNA. (A) OPB-12: (a) ABXR.11B, (b) IZ 987, (c) PF67, (d) PF70, (e) branco; (B) OPX-10: (a) marcador de peso molecular, (b) branco, (c) ABXR.11B, (d) IZ 987, (e) PF67, (f) 18S, (g) 15S, (h) PF70, (i) marcador de peso molecular

14 Dendrograma obtido a partir da matriz de similaridade genética entre as linhagens parentais, seus produtos de fusão e segregantes, a partir dos dados obtidos pelo método RAPD, onde L1 - parental ABXR.11B; L2 - parental IZ 987; L3 - PF67; L4 - segregante 18S; L5 - segregante 15S; L6 - PF70 


\section{LISTA DE TABELAS}

\section{Página}

1 Resumo das características e localização dos genes $F L O$ e seus supressores... 20

2 Requisitos nutricionais e respectivas quantidades diluídas em $10 \mathrm{ml}$ de água... 40

3 Esquema da organização dos meios de cultura para caracterização de mutantes auxotróficos....................................................................... 48

4 Seqüência de nucleotídios e pesos moleculares dos primers

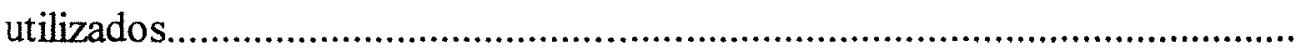

5 Freqüência de obtenção de mutantes auxotróficos das linhagens ABXR.11B e IZ 987 após tratamento com UV e respectiva nomenclatura......................... 59

6 Reversão espontânea dos mutantes auxotróficos das linhagens ABXR.11B e IZ 987.

7 Porcentagem da conversão das células em protoplastos e da regeneração dos protoplastos ( média de duas repetições)...................................................... 64

8 Segregantes parentais e recombinantes dos produtos de fusão.......................... 67

9 Pesos moleculares das bandas cromossômicas das linhagens parentais ABXR.11B e IZ987, produto de fusão 67 e recombinante 15S....................... 69

10 Características das linhagens selecionadas para estudos de cariotipagem

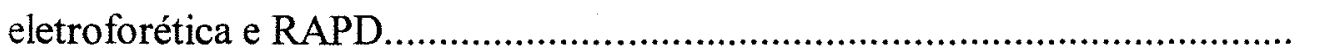




\title{
BIOLOGIA E FUSÃO DE PROTOPLASTOS
}

\section{DE LEVEDURAS FLOCULANTES E $\mathrm{H}_{2} \mathrm{~S}^{-}$}

\author{
Autora: Cleide Viviane Buzanello Martins \\ Orientador: Prof. Dr. Jorge Horii
}

\section{RESUMO}

A utilização industrial de leveduras na produção de bebidas fermentadas é baseada na fermentação alcoólica, onde ocorre a produção de álcool etílico a partir de carboidratos fermentáveis. As linhagens selecionadas para este fim, apresentam diversas características pertinentes ao processo produtivo, entre elas a capacidade de floculação e a não produção de $\mathrm{H}_{2} \mathrm{~S}$, como destacado no presente trabalho. Do ponto de vista econômico, para as indústrias de bebidas fermentadas não destiladas, a floculação é vantajosa quando atinge o estágio final da fermentação, enquanto que a presença de $\mathrm{H}_{2} \mathrm{~S}$ no produto final confere odor desagradável, alterando o flavour da bebida. Assim sendo este estudo teve por objetivos obter linhagens de leveduras floculantes e $\mathrm{H}_{2} \mathrm{~S}$ e caracterizar geneticamente os parentais, bem como analisar os produtos de fusão e os recombinantes obtidos. As linhagens ABXR.11B (floculante) e IZ $987\left(\mathrm{H}_{2} \mathrm{~S}^{-}\right)$foram utilizadas no cruzamento via fusão de protoplastos. A taxa de fusão de protoplastos foi de $2,7 \times 10^{-4}$ entre os mutantes $\arg$ ( $A B X R .11 B$ ) e $p d x^{\circ}$ (IZ 987). Não foi obtido nenhum produto de fusão estável, mas foram selecionados recombinantes com as características de interesse. A caracterização genética foi realizada por cariotipagem eletroforética e marcadores RAPD. Os padrões eletroforéticos dos parentais foram muito diferentes. A 
linhagem IZ 987 mostrou resolução de 6 bandas cromossômicas (2,3 a 1,125 Mb), enquanto que a linhagem ABXR.11B mostrou resolução de 14 bandas cromossômicas $(2,09$ a $0,215 \mathrm{Mb})$. Isto indica uma grande distância taxonômica entre os parentais o que pode explicar a instabilidade dos produtos de fusão. O padrão de um produto de fusão foi complementar entre os respectivos padrões parentais. A análise dos resultados obtidos por RAPD demonstraram que um dos produtos de fusão (denominado PF67) é um hibrido, com padrão de amplificação complementar entre as linhagens parentais. 


\section{BIOLOGY AND PROTOPLAST FUSION AMONG FLOCCULANT AND $\mathrm{H}_{2} \mathrm{~S}$ YEASTS.}

Author: Cleide Viviane Buzanello Martins

Adviser: Prof. Dr. Jorge Horii

\section{SUMMARY}

The industrial use of yeast in the production of fermented beverages is based on alcoholic fermentation, where ethanol production occurs from fermentable carbohydrates. Selected strains for this purpose show several characteristics related to the producing process and among them are flocculation capacity and lack of $\mathrm{H}_{2} \mathrm{~S}$ production, as reinforced in the present work. From an economic point of view non distillated fermented beverage industry flocculation is advantageous during the final stage of fermentation, whereas $\mathrm{H}_{2} \mathrm{~S}$ occurance in the final product gives an appearance undesirable odor, altering the beverage flavour. Therefore, this study was done to obtain flocculant, $\mathrm{H}_{2} \mathrm{~S}^{-}$strains and geneticaly characterize the parent strains, as well as to analyse fusion products and recombinants. A strains ABXR.11B (flocculant) and IZ $987\left(\mathrm{H}_{2} \mathrm{~S}\right)$ were crossed through protoplast fusion. Fusion rate of $2,7 \times 10^{-4}$ for the arg mutant (ABXR.11B) and $p d x^{-}$(IZ987) cross was observed. Stable fusion products were not obtained, but recombinants with the desirable characteristics were selected. Genetic characterization was done by electrophoretic karyotyping and RAPD markers. The parental electrophoretic patterns were strikly different. The strain IZ 987 resolved into 6 
bands $(2,3$ to $1,125 \mathrm{Mb})$, whereas strain ABXR.11B resolved into 14 bands $(2,09$ to $0,215 \mathrm{Mb}$ ). This indicates a great taxonomic distance between the parent strains, what may explain fusion product instability. The pattern of one fusion product was complementary to the patterns of its respective parents. The results obtained from RAPD analysis showed fusion product 67 to be a hybrid, with amplification pattern complementary to the parent strains. 


\section{INTRODUÇÃo}

As leveduras são, sem dúvida, o grupo de microrganismos comercialmente mais explorado pelo homem, uma vez que muitas de suas propriedades biológicas têm aplicações industriais (Rose \& Harrison, 1970). O uso industrial de linhagens de leveduras se dá pelos processos de fermentação anaeróbicos, que são empregados para manufatura de produtos baseados no etanol, e por sistemas aeróbicos, criados para produzir leveduras para a panificação e para propósitos nutricionais. Uma de suas características mais requisitadas é a produção de álcool etílico a partir de carboidratos fermentáveis (fermentação alcoólica), processo utilizado na fabricação de bebidas alcoólicas, destiladas e não destiladas (Rose \& Harrison, 1993).

As indústrias que utilizam-se das leveduras nos processos de produção, particularmente as de bebidas alcoólicas, são muito tradicionais, refletindo a atitude conservadora que, em geral, os homens apresentam no tocante à natureza dos alimentos $\mathrm{e}$ bebidas que consomem.

Apesar disso, as indústrias de bebidas alcoólicas apresentaram recentes inovações, pela introdução de benefícios gerados pela bioengenharia e por manipulações genéticas. As indústrias cervejeiras e vinícolas tiveram muitos desafios nos últimos anos como, por exemplo, aumentar a resistência da levedura ao etanol, à temperatura e ao dióxido de carbono e eliminar ou diminuir a produção de compostos que prejudicam a qualidade das bebidas.

A fim de obter linhagens que apresentassem algumas destas propriedades, foram utilizados métodos de manipulação genética. Mas, em função da natureza aneuplóide, diplóide ou poliplóide da maioria das linhagens da indústria cervejeira e vinícola, as técnicas tradicionais de cruzamento têm apresentado pouco 
sucesso. Assim, fez-se necessário a utilização de novas tecnologias, como a fusão de protoplastos e a transformação. Novos genótipos foram obtidos por fusão de protoplasto, os quais apresentaram características recombinantes, enquanto que linhagens transformadas passaram a expressar genes heterólogos (Carrau et al., 1982; Rose \& Harrison, 1993; Hammond, 1993; Kunkee \& Bisson, 1993). Estas técnicas também foram utilizadas para o melhoramento de linhagens utilizadas para a produção de saké (Kodama, 1993) e bebidas destiladas (Watson, 1993).

Outras aplicações das técnicas genéticas são a identificação, caracterização e monitoramento das linhagens utilizadas na produção das bebidas alcoólicas pelo uso de cariotipagem eletroforética (Johnston \& Mortimer, 1986; Degré et al., 1989; Vezinhet et al., 1990; Sheehan et al., 1991; Frezier \& Dubourdieu, 1992) e de marcadores RAPD (Randon Amplified Polimorphic DNA) (Quesada \& Cenis, 1995; Gomes et al., 1995; Couto et al., 1996).

Sabe-se que o sabor, o aroma e a qualidade das bebidas alcoólicas, em especial as não destiladas, são determinados por um complexo e delicado balanço de compostos aromáticos. Isto porque, além da conversão dos carboidratos em etanol e dióxido de carbono, as diferentes linhagens de leveduras produzem uma série de compostos desejáveis e indesejáveis, que resultam em determinados flavour nas bebidas, o que pode afetar a qualidade final das mesmas.

Sendo assim, as leveduras utilizadas na produção de bebidas não destiladas necessitam de características adicionais, tais como a produção de baixos níveis de ácidos voláteis (Kunkee \& Amerine, 1970) e a produção de baixos níveis de $\mathrm{H}_{2} \mathrm{~S}$ (Parish \& Carrol, 1987; Hammond, 1993). O $\mathrm{H}_{2} \mathrm{~S}$ é um composto indesejável que apresenta odores desagradáveis, que depreciam seriamente a qualidade das bebidas (Vine, 1993).

A floculação é outra característica de interesse em linhagens utilizadas pelas indústrias de bebidas alcoólicas, que mais recentemente tem sido introduzida por modificações genéticas nesses microrganismos (Varnam \& Sutherland, 1994). Este fenômeno é apresentado por algumas linhagens de leveduras que, em certas 
circunstâncias, tendem a aglomerar-se e formar flocos, os quais se depositam no fundo da dorna de fermentação.

Nas indústrias de bebidas fermentadas não destiladas, onde faz-se necessário retirar o fermento da bebida, a ocorrência da floculação das leveduras é vantajosa quando a fermentação alcança o estágio desejado.

O presente trabalho tem por objetivo obter linhagens de leveduras que tenham a capacidade de flocular e não sejam produtoras de $\mathrm{H}_{2} \mathrm{~S}$, pois, tanto a não produção de $\mathrm{H}_{2} \mathrm{~S}$ quanto o alto grau de floculação ocorrem, cada uma, em apenas $1 \%$ das linhagens selvagens de leveduras (Romano, et al., 1985). Desta forma, torna-se improvável que ocorram linhagens que possuam as duas características. Como a linhagem não produtora de $\mathrm{H}_{2} \mathrm{~S}$ tem incompatibilidade sexual com padrões de mating-type de Saccharomyces cerevisiae, o cruzamento das linhagens foi feito via fusão de protoplastos.

Objetiva-se, também, proceder a caracterização genética dos parentais, dos produtos de fusão e de seus segregantes por meio de cariotipagem eletroforética e marcadores RAPD. 


\section{REVISÃO DE LITERATURA}

As leveduras representam os microrganismos economicamente mais explorados pelo homem, e seu uso mais intensivo dá-se na indústria de bebidas alcoólicas. O microrganismo utilizado mais amplamente é a espécie Saccharomyces cerevisiae que apresenta características inerentes ao processo produtivo, sendo essas específicas para cada linhagem. Selecionou-se duas dessas importantes características para a vinificação, para por meio de cruzamentos, unir num só organismo estas habilidades: a incapacidade de produzir $\mathrm{H}_{2} \mathrm{~S}$ e a floculação.

Sendo o objetivo principal deste trabalho a obtenção de linhagem com ambas as características, bem como a análise molecular dos parentais e segregantes, a revisão de literatura a ser apresentada a seguir consistirá dos seguintes tópicos: (a) uma abordagem geral sobre a característica produção ou não de $\mathrm{H}_{2} \mathrm{~S}$; (b) outra a respeito do fenômeno floculação; (c) um levantamento de trabalhos que fizeram uso da técnica de fusão de protoplastos em leveduras; e (d) análise molecular via cariótipo eletroforético e RAPD.

\subsection{Produção de $\mathrm{H}_{2} \mathrm{~S}$}

A habilidade das leveduras para formar $\mathrm{H}_{2} \mathrm{~S}$ tem grande importância comercial. Isto é mais óbvio em certas indústrias de bebidas alcoólicas, tais como vinho e cerveja, onde $\mathrm{o}_{2} \mathrm{~S}$ e os compostos dele derivados podem ocorrer em concentrações indesejáveis no produto final. 
Quase todas as linhagens utilizadas comercialmente podem reduzir sulfato à sulfeto e as enzimas responsáveis foram isoladas de diversas linhagens de Saccharomyces.

\subsubsection{Sulfeto de hidrogênio e bebidas fermentadas}

$\mathrm{O}$ controle e prevenção da formação e a remoção do $\mathrm{H}_{2} \mathrm{~S}$ é de grande importância na produção de bebidas alcoólicas. Isto porque este gás e os produtos dele derivados podem ser produzidos em quantidades que deterioram os produtos, acarretando perdas econômicas. Nos produtos destilados, o $\mathrm{H}_{2} \mathrm{~S}$ e seus derivados são menos nocivos, pois a maioria destes compostos podem ser removidos durante o estágio de destilação, apesar de, segundo Wainwright (1971), poucas informações ter-se a esse respeito.

$\mathrm{Na}$ indústria vinícola, este problema tem sido amenizado. Conforme Reed \& Nagodawithana (1988) isso decorreu da inoculação com leveduras secas de linhagens puras e/ou melhoradas geneticamente e a caracterização das linhagens introduzidas, quanto à produção de $\mathrm{H}_{2} \mathrm{~S}, \mathrm{SO}_{2}$ e ácidos voláteis. Assim, as leveduras selecionadas produzem alto teor de álcool e elaboram substâncias aromáticas (bouquet de fermentação) agradáveis e impedem a formação de ácidos voláteis e ésteres de sabores desagradáveis (Vogt, 1972).

A presença de $\mathrm{H}_{2} \mathrm{~S}$ nos vinhos é facilmente reconhecida (Amerine \& Cruess, 1960). O gosto e cheiro de gás sulfidrico que lembra "ovo podre" é um dos defeitos mais freqüentes na fabricação de vinhos (Lage, 1962). Isso resulta na classificação como odor "anormal", "adquirido" ou "acidental", na degustação dos vinhos o que ocorre também com a deteç̧ão de outros compostos, tais como $\mathrm{CO}_{2}, \mathrm{SO}_{2}$ ou mercaptanos (Peynaud, 1987).

Em função disso, Daudt \& Almeida (1982) excluíram de futuras fermentações a linhagem que produziu $\mathrm{H}_{2} \mathrm{~S}$ apesar de ter apresentado a fermentação e sedimentação mais rápida, no processo de seleção de leveduras para vinificação. 
Na cerveja, segundo Hammond (1993) e Haecht \& Dufour (1995), o $\mathrm{H}_{2} \mathrm{~S}$ formado pela levedura durante o processo fermentativo, contribui para o flavour quando presente em baixa concentração. Porém, este composto quando presente em altas concentrações, pode conferir odor e gosto desagradáveis ao produto.

A quantidade de $\mathrm{H}_{2} \mathrm{~S}$ formada pela levedura durante a fermentação alcoólica depende da linhagem e da temperatura da fermentação. Isso foi demonstrado por Macher ${ }^{1}$, citado por Kunkee \& Amerine (1970). O mesmo foi observado por Zambonelli (1964a) que constatou que as diferenças na redução de sulfatos eram controladas geneticamente. Considerando estas constatações, Wainwright (1971) recomendou a seleção de linhagens estáveis para esta característica.

Rankine (1963) confirmou que leveduras poderiam converter enxofre elementar e dióxido de enxofre a $\mathrm{H}_{2} \mathrm{~S}$, mas o mesmo não ocorre com aminoácidos que contenham enxofre. Este mesmo autor relatou os efeitos da temperatura e valor de $\mathrm{pH}$, potencial redox e o tamanho das partículas de enxofre sobre a formação de $\mathrm{H}_{2} \mathrm{~S}$. Constatou que $\mathrm{pH}$ baixo e temperatura elevada de fermentação estimulam a formação deste composto e ainda que a quantidade de $\mathrm{H}_{2} \mathrm{~S}$ formada a partir do enxofre elementar é inversamente proporcional ao tamanho da partícula. Rankine (1963) concluiu que a taxa de formação de $\mathrm{H}_{2} \mathrm{~S}$ depende da taxa de fermentação e que em estágios acelerados da fermentação há um aumento do uso de enxofre como aceptor de hidrogênio. Além do mais, constatou que a variedade da uva tem pouco efeito sobre a formação do $\mathrm{H}_{2} \mathrm{~S}$, exceto aquelas que podem ter resíduos de enxofre utilizado no controle de bolores indesejáveis.

Por outro lado, Wainwright (1971) apontou para o fato de que muitos fatores influenciariam a produção de $\mathrm{H}_{2} \mathrm{~S}$ e isto indicaria que um grande número de alterações poderiam afetar a quantidade de $\mathrm{H}_{2} \mathrm{~S}$ formada.

Se por um lado há um consenso em afirmar que a intensidade da produção de $\mathrm{H}_{2} \mathrm{~S}$ é influenciada pelas condições culturais, por outro, há opiniões contrastantes quanto aos compostos de enxofre que podem ser reduzidos. Mas, em geral, parece comprovado que a maior produção é obtida do enxofre elementar (Amerine \&

\footnotetext{
${ }^{1}$ Macher, L. Dt. LebensmittRdsch, v.48, p.183-189.
} 
Cruess, 1960), este seguido dos sulfitos, e depois dos tiossulfatos e sulfatos; não é claro o comportamento quando se trata de compostos orgânicos do enxofre (Zambonelli, 1964a).

Uma vez que o enxofre elementar é a mais importante fonte de $\mathrm{H}_{2} \mathrm{~S}$, é necessário que seja feito o seu controle no mosto. Schütz \& Kunkee (1977) enfatizaram que o controle do $\mathrm{H}_{2} \mathrm{~S}$ poderia ser facilitado, com a redução do uso de enxofre para inibir os bolores. Kunkee \& Bisson (1993) relataram que o enxofre elementar oriundo da pulverização dos vinhedos pode ser removido, com sucesso, pela separação das cascas, antes da fermentação. Para estes autores outra fonte importante de $\mathrm{H}_{2} \mathrm{~S}$ seria a redução de sulfatos dos sucos das uvas e dos sulfitos adicionados ao mosto.

Os fatores que influenciam a produção de $\mathrm{H}_{2} \mathrm{~S}$ a partir de enxofre elementar, segundo Schütz \& Kunkee (1977), seriam: temperatura, condições de oxiredução, quantidade e natureza da partícula de enxofre, concentração de etanol e a fisiologia da levedura. Por outro lado Jiranek et al. (1995a) relataram que a quantidade de $\mathrm{H}_{2} \mathrm{~S}$ formada foi dependente da linhagem da levedura, componente precursor do enxofre, da taxa de crescimento da cultura e da atividade da enzima sulfito redutase antes da depleção do nitrogênio.

Giudici \& Kunkee (1994) obtiveram resultados que demonstraram claramente que a redução de sulfato para sulfito e sulfeto é fortemente influenciada pelo conteúdo de amônio e aminoácidos do meio. Afirmaram, ainda, que a linhagem da levedura influenciou fortemente a quantidade de $\mathrm{H}_{2} \mathrm{~S}$ produzido, onde linhagens sem ou com baixa atividade de sulfito redutase nunca produziriam quantidades detectáveis de $\mathrm{H}_{2} \mathrm{~S}$.

\subsubsection{Mecanismo de produção de $\mathrm{H}_{2} \mathrm{~S}$}

A sintese de $\mathrm{H}_{2} \mathrm{~S}$ em $S$. cerevisiae está relacionada com o metabolismo de alguns aminoácidos e é controlada pela composição destes no meio (Wainwright, 1971). Ele é intermediário na biossíntese de aminoácidos sulfurados, cisteína e metionina, a partir de compostos de enxofre inorgânicos. Esta inter-relação está esquematizada na 
Figura 1. Segundo Stewart \& Russell (1981), o $\mathrm{H}_{2} \mathrm{~S}$, juntamente com dióxido de enxofre, é acumulado quando as taxas de redução de sulfato para sulfito e sulfeto excedem a taxa de formação desses aminoácidos. Geralmente, porém as leveduras produzem $\mathrm{H}_{2} \mathrm{~S}$ suficiente somente para o próprio requerimento biossintético (Jiranek et al., 1995a).

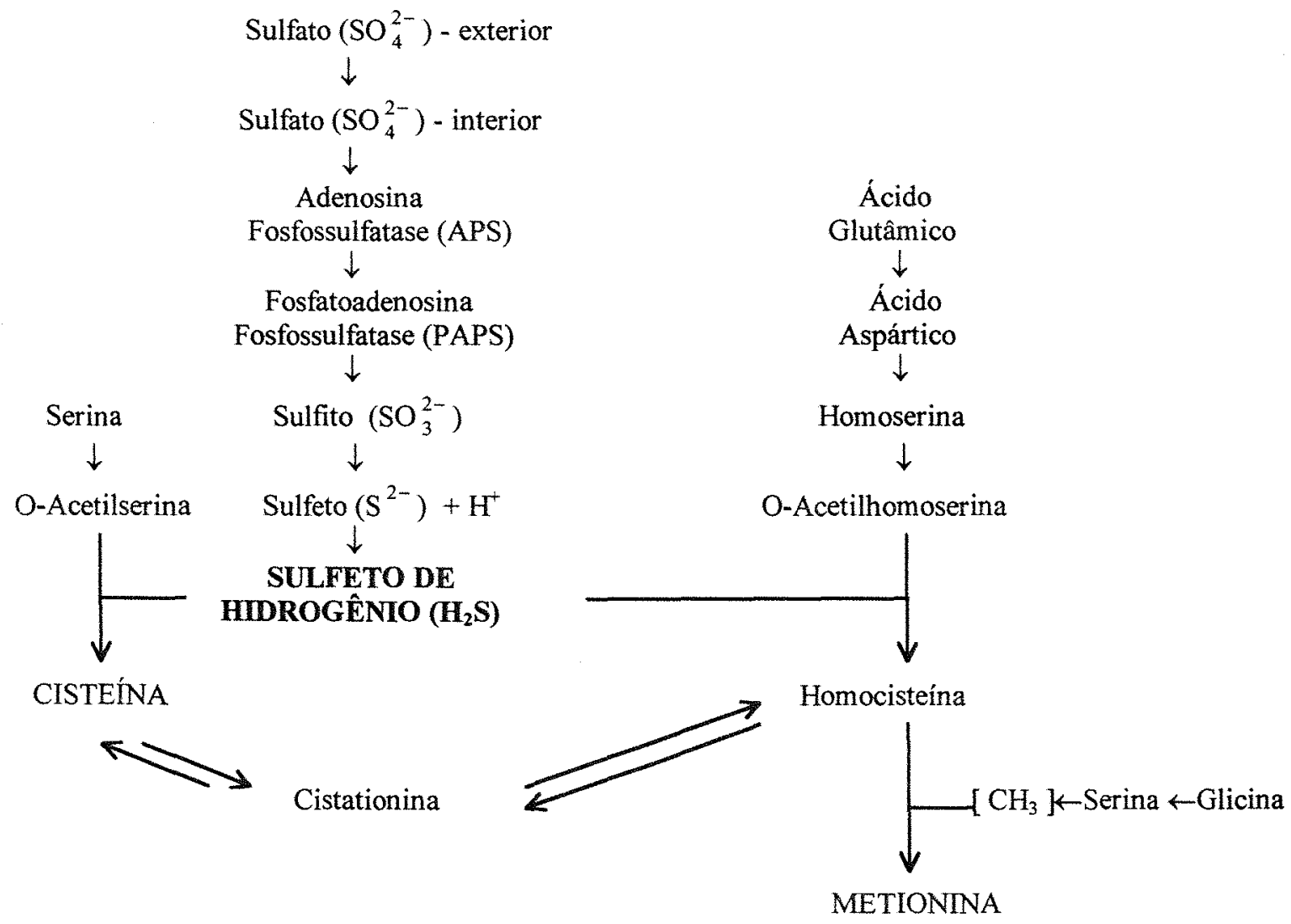

Figura 1- Via de assimilação do sulfato, biossintese da metionina e cisteina e a interrelação com a produção de sulfeto de hidrogênio. (Adaptado de Wainwright, 1971; Vine, 1993; Haecht \& Dufour, 1995).

Wainwright (1970) observou que esses mesmos compostos podem ocorrer quando há carência do fator de crescimento pantotenato. Isso por que, uma vez que a cisteína é degradada a $\mathrm{H}_{2} \mathrm{~S}$ e piruvato pela enzima cisteína dessulfidrase e a reação reversa é catalisada pela enzima cisteína sintetase, a qual requer pantotenato para sua 
atividade. Assim, sob deficiência deste fator de crescimento, a conversão de cisteína a metionina é restringida. Segundo este mesmo autor a metionina inibe a via de redução do sulfato e esta inibição é influenciada pela composição de outros aminoácidos. Por outro lado, Eschenbruch \& Bonish (1976) sugeriram que a baixa produção de $\mathrm{H}_{2} \mathrm{~S}$ na presença de pantotenato indicaria a rápida conversão de cisteína em metionina e a repressão, pelo produto final, do sistema de enzimas que degradam a cisteína.

O sulfeto produzido seria utilizado na reação de sulfidrilação com acetilhomoserina para produzir homocisteína, a qual seria transformada em metionina, numa reação catalisada pela metiltransferase ou em cisteína pela via da trans-sulfuração. Outro caminho para utilizar o sulfeto produzido seria a síntese de cisteína pela sulfidrilação da O-acetilserina (Haecht \& Dufour, 1995).

A sintese do $\mathrm{H}_{2} \mathrm{~S}$ está relacionada ao crescimento. Segundo Hough et al., (1982), durante a fermentação de linhagens de cervejaria a taxa máxima de produção coincide com a taxa máxima de crescimento. Já Nagami ${ }^{2}$ et al., citados por Hammond (1993) observaram que na fermentação da cerveja ocorre produção de $\mathrm{H}_{2} \mathrm{~S}$ em quatro picos, coincidindo com o período em que as células das leveduras não estão em brotamento. Thomas et al. (1993) observaram a ocorrência de dois períodos específicos na produção de $\mathrm{H}_{2} \mathrm{~S}$ durante a fermentação do meio por linhagens de $S$. cerevisiae utilizadas na vinificação. O primeiro pico estava relacionado à linhagem da levedura e foi mais intenso. O segundo foi relacionado ao meio de fermentação. Vine (1993) acrescentou que leveduras selvagens e fermentação tumultuosa estão associadas com altos níveis de $\mathrm{H}_{2} \mathrm{~S}$, com odor de "ovo podre" detectável.

A produção de $\mathrm{H}_{2} \mathrm{~S}$ por outras leveduras de importância comercial, como Candida utilis, não foi estudada em detalhes. Algumas leveduras, como Hansenula suaveolens e Hanseniaspora valbyensis, não apresentaram ação do pantotenato sobre o crescimento ou sobre a produção de $\mathrm{H}_{2} \mathrm{~S}$ e acabaram por formar mais deste composto na presença de metionina. Outras leveduras formam pouco $\mathrm{H}_{2} \mathrm{~S}$ na presença ou ausência de pantotenato ou metionina (Hansenula saturnus, Nadsonia elongata). Há entretanto,

\footnotetext{
${ }^{2}$ NAGAMI, K. ; TAKAHASHI, T.; NAKATANI, K.; KUMADA, J. Technical Quarterly of the
} Master Brewers Association of the Americas. vol. 17. p. 64, 1980. 
outras leveduras que produzem $\mathrm{H}_{2} \mathrm{~S}$ quando há deficiência de pantotenato. Candida pseudotropicalis, Kloeckera antillarum, Saccharomyces rouxii, Saccharomyces ludwigii e Zygosaccharomyces priorianus quando testadas produziram menos $\mathrm{H}_{2} \mathrm{~S}$ na presença de metionina e mais na presença de treonina. Brettanomyces apresentou um comportamento interessante, pois ao mesmo tempo que o pantotenato não age sobre ela, metionina aumentou a produção de $\mathrm{H}_{2} \mathrm{~S}$ (Wainwright, 1971).

\subsubsection{Genética do caráter produção de $\mathrm{H}_{2} \mathrm{~S}$}

Como exposto acima, a produção de $\mathrm{H}_{2} \mathrm{~S}$ está intimamente ligada à linhagem da levedura. Estudos realizados por Zambonelli (1964a), constataram que a capacidade de Saccharomyces cerevisiae produzir $\mathrm{H}_{2} \mathrm{~S}$ a partir de compostos inorgânicos é uma prerrogativa muito comum: pode-se dizer que o incomum é a total incapacidade de produzir este composto e que nas linhagens $\mathrm{H}_{2} \mathrm{~S}$ negativas a falta de capacidade de produzir hidrogênio sulfurado é uma característica fixa e que não se perde com as sucessivas transferências da cultura.

A capacidade de produção de $\mathrm{H}_{2} \mathrm{~S}$ é uma caracteristica que pode ser considerada sob dois aspectos: qualitativo e quantitativo. De fato há linhagens completamente incapazes de produzir este gás a partir de sulfatos e sulfitos e há outros que possuem diferentes teores de produção, variando de quantidade traço até altas concentrações. Tanto do ponto de vista qualitativo quanto quantitativo é um caráter estável, constante e controlado geneticamente.

Pode-se fazer classes de freqüência pela quantidade de produção de $\mathrm{H}_{2} \mathrm{~S}$ e também pela dose mínima de sulfato de onde se obtém a produção do gás. A dose mínima varia de linhagem para linhagem e é maior quanto mais restrita é a atividade da mesma linhagem (Zambonelli, 1964a).

Ainda segundo Zambonelli (1964a), todas as linhagens capazes de reduzir os sulfatos podem também reduzir os sulfitos e vice-versa. Porém, a dosagem mínima a partir da qual é possivel a produção de $\mathrm{H}_{2} \mathrm{~S}$ é diferente: em concentrações iguais de enxofre muitas linhagens produzem $\mathrm{H}_{2} \mathrm{~S}$, mas só de sulfitos e não de sulfatos. 
A partir de experimentos biométricos, Zambonelli (1964b) realizou hibridações entre parentais $\mathrm{H}_{2} \mathrm{~S}$ positivos e negativos. Encontrou todos os hibridos positivos, sendo a quantidade de $\mathrm{H}_{2} \mathrm{~S}$ produzida por estes sempre inferior ao parental positivo, mas relativamente iguais entre os descendentes originados das mesmas matrizes. Procedendo à análise da segregação dos caracteres positivo e negativo, pela micromanipulação dos esporos, Zambonelli constatou que de cada asco com quatro esporos, obtinha-se duas culturas positivas e duas negativas. Ficou comprovado então, que a capacidade ou incapacidade de produzir $\mathrm{H}_{2} \mathrm{~S}$ por parte de Saccharomyces cerevisiae var. ellipsoideus é uma característica hereditária e que segue as Leis de Mendel, com separação dos dois caracteres nos esporos do híbrido na equivalência de $2: 2$.

A não produção de $\mathrm{H}_{2} \mathrm{~S}$ é decorrente de uma mutação no gene que afeta a enzima sulfito redutase e esta propriedade pode ser transferida por técnicas genéticas (Zambonelli et al., 1975) e, como fizeram Romano et al. (1985), no melhoramento de linhagens de vinificação.

Do ponto de vista quantitativo, o caráter produção de $\mathrm{H}_{2} \mathrm{~S}$ segue o modelo hereditário poligênico. Mas alguns resultados obtidos por Zambonelli (1965) chamaram a atenção, pois, sugeriram que o parental negativo não tivesse nenhuma influência sobre os descendentes positivos, num cruzamento entre linhagem positiva (para quantidade traço) e negativa.

$\mathrm{Na}$ tentativa de melhor entendimento da genética deste caráter Takahashi $^{3}$ et al. citados por O’Brien (1990) mapearam o gene responsável pela produção deficiente de $\mathrm{H}_{2} \mathrm{~S}$ (phs) e Takahashi \& Sakai ${ }^{4}$, também citados por O’Brien (1990) fizeram o mapeamento do gene $n h s l$ o qual inibe a produção de $\mathrm{H}_{2} \mathrm{~S}$.

Hidetoshi $^{5}$ et al., citados por Haecht \& Dufour (1995), clonaram um gene de uma linhagem de $S$. cerevisiae que suprime a formação de $\mathrm{H}_{2} \mathrm{~S}$ (NHS5). Esses

3 TAKAHASHI, T.; HOJTO, M.; SAKAI, K. Genes controlling hydrogen-sulfide production in $S$. cerevisiae. Bulletin of Brewing Science, v. 26, p. 29-36, 1980.

${ }^{4}$ TAKAHASHI, T.; SAKAI, K. Mapping of NHS1 gene inhibitor for hydrogen sulfide production in $S$. cerevisiae. Bulletin of Brewing Science, v. 28, p. 1-5, 1983.

$s$ HIDETOSHI, T.; MOVI, T.; OKUMURA, Y.; KITABAKATE, K.; TSUMURA, Y. Journal of American Brewing Chemistry, v. 50, p. 130-133, 1992. 
autores demonstraram que o gene NHS5 afeta o caminho de homocisteína para glutationa, aumentando a cisteína. $O$ gene provavelmente afeta a atividade da cistationa sintetase, a qual catalisa uma etapa na transformação de homocisteina para cistationina. $O$ $\mathrm{H}_{2} \mathrm{~S}$ formado na célula da levedura deveria, deste modo, ser convertido em cisteína, $\gamma$ glutamilcisteína e glutationa e, conseqüentemente, o nível de $\mathrm{H}_{2} \mathrm{~S}$ livre na célula deveria decrescer e somente pequenas quantidades seriam excretadas durante a fermentação. Os genes envolvidos na via metabólica do sulfato em Saccharomyces cerevisiae estão esquematizados na Figura 2.

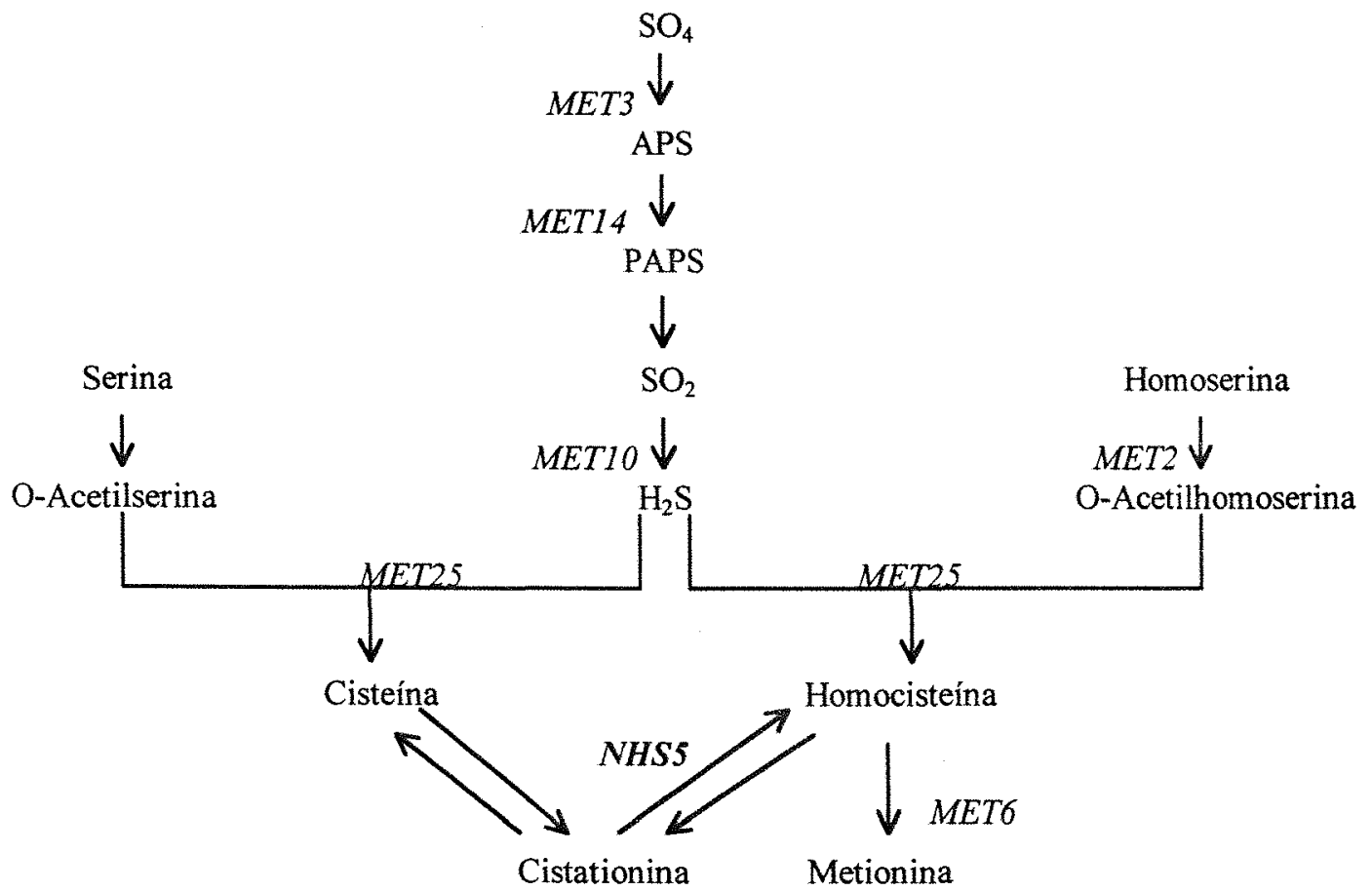

Figura 2 - Genes envolvidos na via metabólica do sulfato em Saccharomyces cerevisiae. MET2: homoserina acetiltransferase; MET3: ATP sulfurilase; MET6: homocisteína metiltransferase; MET10: sulfito redutase; MET14: APS quinase; MET25: O-acetilhomoserina e O-acetilserina sulfidrase; NHS5: cistationina $\beta$ sintetase (Hammond, 1995). 


\subsubsection{Formação de $\mathrm{H}_{2} \mathrm{~S}$ por desaminação proteolítica}

Deficiência em vitaminas essenciais, bem como nitrogênio amino livre (FAN), estão associados com o aumento da produção de $\mathrm{H}_{2} \mathrm{~S}$ devido à estimulação das reações de desaminação proteolítica, desencadeado pelo estresse das leveduras (Vine, 1993).

Em algumas circunstâncias, apesar do controle efetivo para a não produção de $\mathrm{H}_{2} \mathrm{~S}$, o mesmo era produzido em quantidade excessiva. Vos \& Gray (1979) realizaram experimentos a fim de determinar a causa da esporádica produção de $\mathrm{H}_{2} \mathrm{~S}$ em mostos onde fontes de enxofre elementar eram eliminadas, onde eram utilizadas linhagens de leveduras apropriadas para controlar a formação do $\mathrm{H}_{2} \mathrm{~S}$ durante a fermentação, e quantidades excessivas de certos íons metálicos eram evitadas.

Vos \& Gray (1979), para realizarem estudos, basearam-se em investigações que indicavam que dos vários constituintes do mosto, o teor de nitrogênio poderia estar relacionado com o desenvolvimento de $\mathrm{H}_{2} \mathrm{~S}$. Pelos resultados obtidos concluíram que leveduras em fermentação ativa eram capazes de desenvolver atividade proteolítica extracelular e que a degradação das proteínas do mosto estaria implicada na formação do $\mathrm{H}_{2} \mathrm{~S}$. Sugeriram ainda que a formação deste composto ocorre indiretamente, como resultado da demanda de nitrogênio pela levedura e não por causa do seu requerimento do enxofre como tal.

A hipótese formulada por Vos \& Gray (1979), para explicar o mecanismo de produção do $\mathrm{H}_{2} \mathrm{~S}$, está esquematizada na Figura 3. Esta hipótese parte do pressuposto que o metabolismo das leveduras durante a fermentação alcoólica demanda primariamente a presença de açúcares assimiláveis e compostos de nitrogênio. A inversa relação entre FAN e $\mathrm{H}_{2} \mathrm{~S}$ implicaria que quando o conteúdo de nitrogênio assimilável no mosto fosse insuficiente para o metabolismo ótimo, a atividade proteolítica das leveduras seria estimulada. Proteínas e peptídeos de alto peso molecular seriam degradados até formas assimiláveis num esforço para suplementar tais deficiências, durante este processo o enxofre derivado das proteínas seria liberado como $\mathrm{H}_{2} \mathrm{~S}$. 


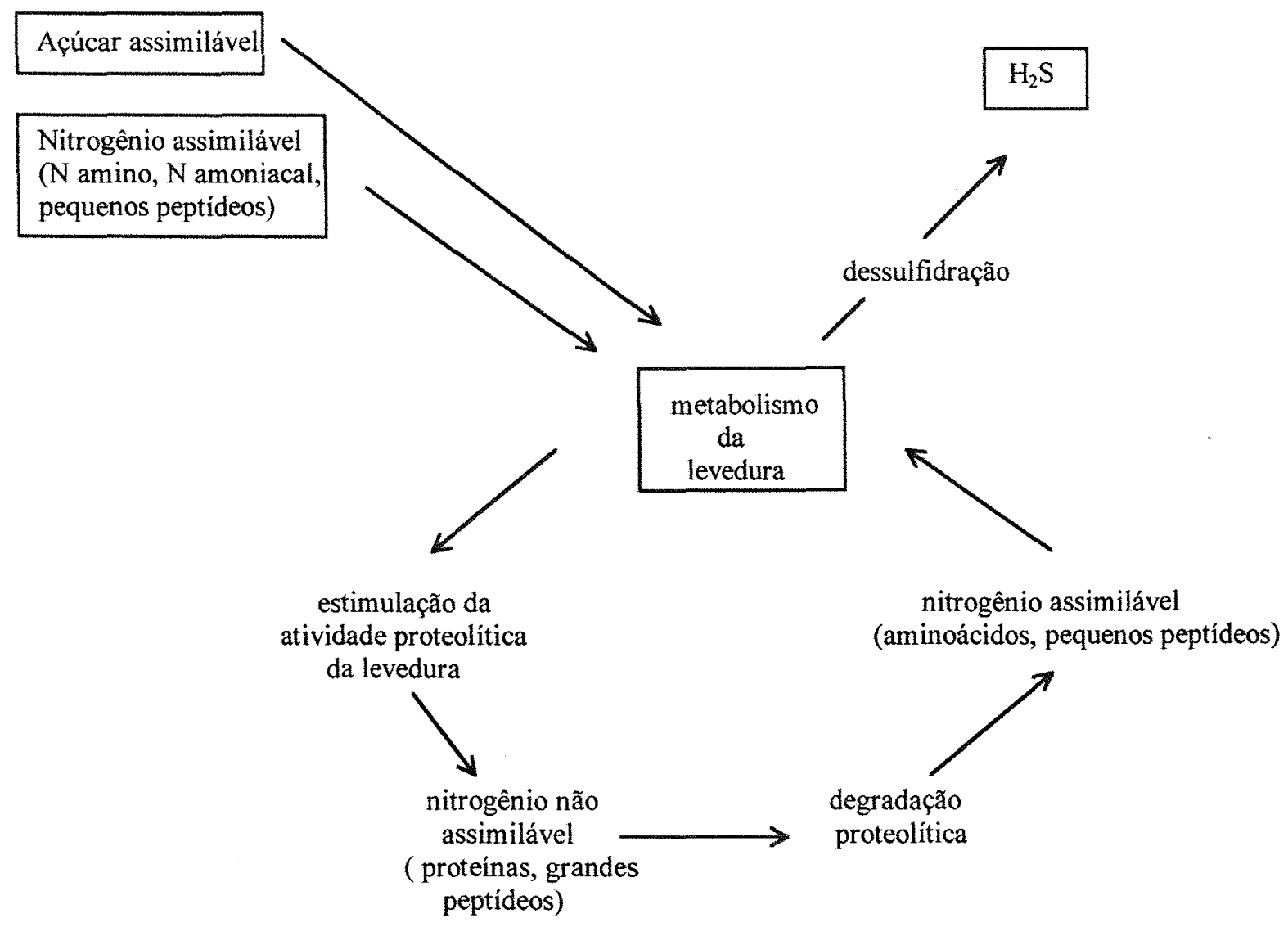

Figura 3 - Mecanismo de desenvolvimento de $\mathrm{H}_{2} \mathrm{~S}$ durante a fermentação em mostos deficientes em nitrogênio assimilável (Vos \& Gray, 1979).

Contrapondo-se a esta teoria, Giudi \& Kunkee (1994) sugeriram que o sulfato seria a principal fonte de $\mathrm{H}_{2} \mathrm{~S}$ nos mostos deficientes em nitrogênio, especialmente se não houvesse a adição prévia de dióxido de enxofre. Isto foi levantado baseados no fato de que a quantidade de dióxido de enxofre produzida foi fortemente afetada pela concentração de amônio e, pelo fato de que a metionina reprime a produção de sulfito e sulfeto.

Por outro lado Jiranek et al. (1995a) relataram que a rota de formação do $\mathrm{H}_{2} \mathrm{~S}$ pela ação de enzimas hidrolizadoras da cisteína em meio de suco de uva quimicamente definido e em vinicultura, por diversas razões parece não ser relevante. $O$ meio quimicamente definido utilizado por estes autores não continha cisteína e o mosto 
da uva tipicamente apresenta somente quantidades traço deste aminoácido. Assim sendo uma atividade autolítica ou proteolítica teria pouco impacto na produção de $\mathrm{H}_{2} \mathrm{~S}$ uma vez que a proteína, da qual seria liberada a cisteína estava ausente do meio definido.

\subsection{Floculação}

A floculação é um fenômeno apresentado por determinadas leveduras, as quais se agregam espontaneamente formando flocos. Esses são constituídos por milhares de células, que sedimentam-se rapidamente no meio de fermentação no qual estão suspensas. A floculação é uma das importantes propriedades de determinadas linhagens de leveduras utilizadas em fermentações industriais, tais como: cervejaria (Greenshields \& Smith ${ }^{6}$, citados por Atkinson \& Daoud, 1976); na vinificação (Varnam \& Sutherland, 1994); na produção de etanol (Lee et al., 1982), na produção de biomassa (Smith \& Greenshields ${ }^{7}$, citados por Atkinson \& Daoud, 1976), na produção de proteína microbiana utilizando Candida intermedia (Gasner \& Wang ${ }^{8}$, citados por Atkinson \& Daoud, 1976).

A eficiência do processo fermentativo é dada em função direta da manutenção das células ativas dispersas no mosto, em contato com o substrato. Assim sendo, a remoção precoce das células devido à floculação provoca redução do rendimento e aumenta o tempo de fermentação, com perdas econômicas significativas (Atkinson \& Daoud, 1976; Rose, 1980). Mas, se a floculação ocorrer num ponto desejável da fermentação, atuará eficientemente na remoção das células do mosto (Calleja, 1987). Isto pode, desta forma, contribuir na diminuição do custo do processo e aumentar sua produtividade (Prince \& Bardford, 1982; Netto et al., 1985).

As leveduras selecionadas para a produção de cerveja apresentam a capacidade de flocular no final da fermentação (Mill, 1964b). Assim, estudos sobre a floculação foram realizados visando a melhoria do processo fermentativo, sendo que a

\footnotetext{
${ }^{6}$ GREENSHIELDS, R. N.; SMITH, E. L. Chem. Engr. n. 249, p. 182, 1971.

${ }^{7}$ SMITH, E. L.; GREENSHIELDS, R. N. Chem. Engr. n. 281, p. 28, 1974.

${ }^{8}$ GASNER, L. L.; WANG, D. I. C. Biotechnol. Bioeng., v. 12, p.127, 1970.
} 
maioria deles utilizou leveduras da espécie S. cerevisiae (Mill, 1964b; Jayatissa \& Rose, 1976) e linhagens da indústria cervejeira (Stewart \& Russel, 1986).

Apesar dos estudos sobre floculação serem basicamente realizados em S. cerevisiae, outros gêneros de leveduras começam a serem investigados: Hansenula anomala Kluyveromyces bulgaricus, Kluyveromyces marxianus, Pichia pastoris, Saccharomycodes ludwigii e Schizosaccharomyces pombe. Mas a genética da floculação só tem sido estuda em Saccharomyces cerevisiae (Stratford, 1992b).

As indústrias de bebidas fermentadas, como a cerveja e o vinho, necessitam de linhagens com característica específicas. Espera-se que elas cresçam e fermentem como células isoladas, e que iniciem a floculação imediatamente após a exaustão do açúcar do mosto para "limpar" a bebida. As células colhidas poderão iniciar nova fermentação (Stratford \& Carter, 1993).

$\mathrm{O}$ interesse da floculação tanto de $S$. cerevisiae quanto de outros gêneros de leveduras se dá por dois motivos. O primeiro, diz respeito à separação econômica das células do produto fermentado no final da fermentação, enquanto que o segundo deriva do interesse comercial do uso de leveduras imobilizadas em fermentações (Stratford, 1992b).

\subsubsection{Tipos de agregação celular}

Os mecanismos que provocam os diferentes tipos de agregação celular são variados mas aparentemente similares. Destacam-se: agregação sexual (Calleja, 1987); formação de cadeias (Eddy, 1955); e a floculação propriamente dita (Rose, 1980; Stewart \& Russel, 1986).

Os agregados sexuais ocorrem como um prelúdio a fusão sexual após contato das células de mating type compatíveis (Stratford, 1992b). É um estado temporário e depende da complementaridade entre linhagens haplóides (Johnson et al., 1988) e de colisões entre as células. Não apresenta requerimento específico para cálcio e é insensível a açúcares e a agentes quelantes (Calleja, 1987). 
A agregação sexual de Saccharomyces cerevisiae, Hansenula wingei e Schizosaccharomyces pombe envolve reconhecimento de glicoproteínas e ligação entre as linhagens complementares (Johnson et al., 1988). O mesmo foi observado por Johnson et al. (1988), que relataram que a co-floculação sexual seria mediada, predominantemente, por interações do tipo proteína-proteína entre as células.

A formação de cadeias em leveduras constitui uma outra forma de agregação celular do tipo passivo (Stewart, 1981). Estes agregados são formados por falhas na separação dos brotos da célula-mãe após a divisão celular (Gilliland ${ }^{9}$, citado por Stratford \& Assinder, 1991; Eddy, 1955). Após sucessivos ciclos de divisões celulares as leveduras formam cadeias com cerca de 30 a 50 células (Stratford, 1992b). É uma característica hereditária e parece estar relacionada com o desenvolvimento, morfogênese e diferenciação celular (Calleja, 1987) e constitui-se num fenômeno distinto da floculação (Eddy, 1955).

Uma vez dispersas as cadeias por ação mecânica, as células não conseguem se reagregar. Como possíveis causas desta agregação são apontadas a deficiência em biotina ou inositol (Dunwell et al., 1961).

A floculação assexual ou floculação propriamente dita em leveduras é um fenômeno de agregação celular do tipo ativo e reversível. A floculação é um agregado estável decorrente de colisões ao acaso das células (Stewart, 1981). Pode ser considerada como um mecanismo de sobrevivência (Stratford, 1992a). Possivelmente seja mediada por proteínas situadas na superficie celular que pela ativação por íons $\mathrm{Ca}^{++}$interagiriam com carboidratos para formar um complexo proteína-carboidrato (Miki et al., 1982). Outros cátions metálicos poderiam ser requeridos além do cálcio (Mill, 1964b).

\subsubsection{Controle da floculação}

A floculação é controlada por um complexo de inter-relações de fatores genéticos, fisiológicos e ambientais. Assim, as modificações que geram a floculação das

${ }^{9}$ GILLILAND, R. B. The flocculation characteristics of brewing yeasts during fermentation. In: EUR. BREW. CONV. PROC. CONGR. Brighton, 1951. P. 35-58. 
células de levedura são oriundas das mudanças na estrutura química de suas paredes celulares, resultantes dos processos metabólicos do organismo (Mill, 1964a). Deste modo, mesmo em circunstâncias onde o genótipo das células e as condições fisiológicas permitam a floculação, sua realização depende ainda de condições ambientais favoráveis (Esser \& Kües, 1983). A Figura 4 esquematiza a inter-relação dos fatores que controlam a floculação.

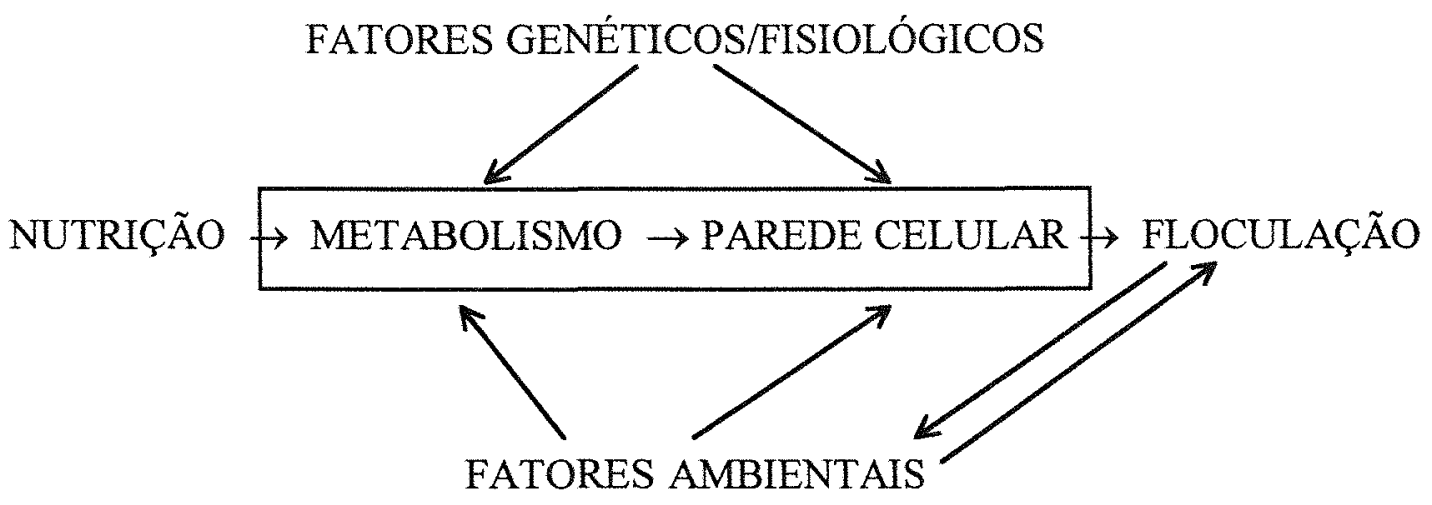

Figura 4 - Controle direto ou indireto da floculação de microrganismos (Atkinson \& Daoud, adaptado por Bromberg, 1994).

\subsubsection{Fatores genéticos}

A floculação é uma característica controlada geneticamente, sendo dominante sobre a não floculação (Gilliland ${ }^{10}$; Thorne ${ }^{11}$, citados por Stratford, 1992b). $\mathrm{Na}$ linhagem estudada por Gilliland a floculação foi determinada por um loco simples, enquanto que os resultados obtidos por Thorne sugeriram o envolvimento de 3 locos não ligados dentro de uma só linhagem. Com o aumento do número de genes dominantes aumentou a estabilidade da floculação, mas sua intensidade não foi alterada.

${ }^{10}$ GILLILAND, R B. The floccculation characteristics of brewing yeasts during fermentation. In: EUR. BREW. CONV. PROC. CONGR. Brighton, 1951. Proc. Eur. Brew. Conv. Congr. p. 3558.

11 THORNE, R. S. W. Some aspects of yeast flocculance. In: EUR. BREW. CONV. PROC. Brighton, 1951. Proc. Eur. Brew. Conv. Congr. p. 21-34. 
Além do controle cromossômico (Miki et al., 1982), a floculação é controlada por fatores genéticos extracromossômicos (Wilkie \& Evans, 1982). O DNA mitocondrial atua na modulação dos genes podendo acarretar mudanças na parede celular, uma vez que foram obtidos mutantes deficientes respiratórios provenientes de leveduras floculantes que tiveram sua capacidade de flocular modificada (Wilke \& Evans, 1982; Evans et al., 1982; Hinrichs et al., 1988).

A floculação se dá pela presença dos genes FLO. Lewis et al. (1976) verificaram que os genes $F L O 1$ e $F L O 2$ eram dominantes e fortemente ligados, enquanto que o flo3 era recessivo. Outros genes dominantes foram descobertos: FLO4 (Stewart \& Russel, 1977); FLO5 (Johnson \& Reader ${ }^{12}$, citados por Stratford, 1992b); e FLO8 (Yamashita \& Fukui, 1983).

Russel et al (1980) demonstraram que os genes FLO1, FLO2 e FLO4 eram alélicos e localizavam-se no cromossomo I. Johnson \& Reader ${ }^{12}$, citados por Stratford (1992b), constataram que o gene FLO5 não era alélico com FLOI e conferia forte floculação. O gene FLO8 foi mapeado por Yamashita e Fukui (1983) no cromossomo VIII, ligado ao gene arg4. Mais recentemente, Vezinhet et al. (1991) mapearam o gene FLO5, o qual também se encontra no cromossomo I. Na Tabela 1 encontram-se sumarizados os genes $F L O$ envolvidos na floculação.

A instabilidade das leveduras quanto a floculação traz constantes prejuízos econômicos à indústria de cerveja. Algumas causas da perda da floculação podem ser dadas por alterações no meio de cultivo, mas não há dúvidas que seja uma propriedade instável (Stewart, 1975). A instabilidade e perda da floculação foi relatada em linhagens geneticamente definidas como FLO1, onde foi demonstrado por análise de tétrades a segregação da característica pela origem de linhagens floculantes e não floculantes (Lewis et al., 1976; Russel et al., 1980). Os genes flo6 e flo7 foram indicados como formas alélicas do gene FLO1(Johnston \& Reader $^{13}$, citados por Stratford, 1992b).

\footnotetext{
12 JOHNSTON, J. R.; READER, H. P. Genes conferring and suppressing flocculation in brewing and laboratory strains of Saccharomyces. Proc. 11th Int. Conf. on Yeast Genetics and molecular Biology. Montpelier, 1982. p. 124.

13 JOHNSTON, J. R; READER, H. P. Genes conferring and suppressing flocculation in brewing and laboratory strains of Saccharomyces. Proc. 11th Int. Conf. on Yeast Genetics and molecular Biology. Montpelier, 1982. p. 124.
} 
Tabela 1 - Resumo das características e localização dos genes $F L O$ e seus supressores.

\begin{tabular}{lccc}
\hline Gene & Localização & Dominância & Comentários \\
\hline FLO1 & cromossomo I & dominante & \\
FLO2 & & dominante & alélico com FLO1 \\
flo3 & recessivo & \\
FLO4 & & dominante & alélico com FLOI \\
FLO5 & cromossomo I & dominante & \\
flo6 & & semi-dominante & possível alelo FLO1 \\
flo7 & & semi-dominante & possível alelo FLO1 \\
FLO8 & cromossomo VIII & dominante & \\
fsu1 & & semi-dominante & supressor FLO4 \\
fsu2 & & semi-dominante & supressor FLO4 \\
\hline
\end{tabular}

Fonte: Stratford (1992b).

A supressão da floculação tem bases genéticas. Está representada pelos genes $f s u 1$ e $f s u 2$, os quais suprimem o gene FLO4 e por mutações mitocondriais (Stewart \& Russel, 1977).

Além da presença dos genes $F L O$, a floculação pode ser causada em decorrência de uma série de mutações. A maioria dessas mutações dão-se nos locos TUP1 e CYC8, nos cromossomos III e II, respectivamente. As mutações tup1 e cyc8 apresentam efeitos pleiotrópicos idênticos (Stratford, 1992b).

\subsubsection{Fatores fisiológicos}

A floculação decorre de inúmeras inter-relações e para que ocorra, torna-se necessário o envolvimento do metabolismo da célula como um todo. Mas, uma vez estabelecida, a floculação torna-se uma propriedade da parede celular, visto que esta estrutura mantém a capacidade floculante dos microrganismos (Mill, 1966). 
Observou-se que a floculação de leveduras aumenta rapidamente na metade final da fase exponencial de crescimento (Mill, 1964a) e segundo Stratford \& Assinder (1991) esta formação geralmente ocorre no final da fase exponencial ou durante a fase estacionária. Bielecki \& Brzeski (1989), contrapondo-se aos autores acima, relataram a ocorrência de floculação em células de Saccharomyces cerevisiae durante todos os estágios do crescimento, sugerindo que este fenômeno seja dependente da disponibilidade de sítios receptores, necessitando ainda, que os mesmos encontrem-se em correta conformação para que as células formem agregados estáveis. Mas, segundo Stewart (1981), os flocos são formados na fase estacionária de crescimento, na ausência de divisão celular.

Mill (1964a) apontou para o fato de que quanto menos floculante for a levedura, mais rápido ela cresce. Sabendo que a floculação é influenciada pela nutrição, Mill realizou experimentos, observando que as células não se agregavam na ausência de glicose, mas floculavam rapidamente na presença de glicose somente ou de glicose $\mathrm{e}$ extrato de levedura. Este mesmo autor constatou que a presença de amônia retardava a floculação. Patel \& Ingledew (1975), verificaram que o grau de floculação está diretamente relacionado com os níveis de glicogênio ácido-solúvel intracelular.

A síntese de proteínas citoplasmáticas também parece estar associada com o desenvolvimento das características floculantes de leveduras, uma vez que, a cicloheximida apresenta efeito inibitório sobre a floculação (Nishihara et al., 1976).

A parede celular está intimamente relacionada com a floculação. Hough et al. (1971) realizaram experimentos nos quais isolaram a parede celular e testaram sua capacidade para formar flocos. Demonstraram que as paredes celulares obtidas de células integras que floculavam, permaneceram com tal habilidade, enquanto que as obtidas de células não floculantes não foram capazes de se agregar. $\mathrm{O}$ mesmo foi observado por Nishihara et al. (1982) e Amri et al. (1982). 


\subsubsection{Fatores ambientais}

Os fatores ambientais que afetam a floculação podem ser agrupados em efeitos físicos, químicos e biológicos, de acordo com sua ação e sua influência. Podem exercer seu efeito por vários mecanismos, onde a ação individual de um fator sobre a floculação pode ser de maneira direta ou indireta ou dependendo da natureza da ação, esta pode ter efeitos reversíveis ou uma mudança permanente (Atkinson \& Daoud, 1976).

Entre os efeitos físicos destacam-se a temperatura e a agitação que é requerida para superar a repulsão eletrostática entre as células. Atkinson \& Daoud (1976) constataram por meio de experimentos que os flocos permaneceram estáveis numa faixa de 20 a $50^{\circ} \mathrm{C}$ e altas temperaturas provocaram a desfloculação, e a $80^{\circ} \mathrm{C}$ a floculação cessou por completo. Em outro estudo sobre a influência da temperatura sobre a floculação, Kamada \& Murata (1984) verificaram o aumento da taxa de floculação de linhagens de Saccharomyces, com o aumento gradativo da temperatura de $0^{\circ} \mathrm{C}$ a $30^{\circ} \mathrm{C}$.

A presença de certos elementos e compostos químicos no substrato afetam a floculação. Podem ser nutrientes ou produtos do metabolismo microbiano. Dos efeitos químicos que influenciam a floculação pode-se citar o $\mathrm{pH}$, o qual pode provocar uma alteração profunda na floculação (Atkinson \& Daoud, 1976), sendo o pH ótimo dependente de cada linhagem (Calleja, 1987).

$O$ efeito de sais na floculação é complexo e depende de algumas variáveis como: tipo do cátion, linhagem da levedura, valor do $\mathrm{pH}$ e força do tampão (Stratford \& Brundish, 1990). Os flocos de leveduras são dispersos quando se remove os íons cálcio, seja por lavagem com água ou pela ação de agentes quelantes como o EDTA (Taylor \& Orton, 1975). Porém, rapidamente retomam a floculação pela adição de novos íns cálcio. Outros efeitos químicos são devidos a solventes orgânicos e substâncias nitrogenadas.

Dentre os fatores biológicos que podem influenciar a floculação destacam-se: a concentração microbiana inicial, a concentração dos flocos já formados 
(Atkinson \& Daoud, 1976) e a interação entre diferentes microrganismos numa cultura mista (Esser \& Kües, 1983).

\subsubsection{Teorias moleculares da floculação}

Não há concordância na literatura quanto a explicação do processo de floculação, mas existem algumas hipóteses que tentam explicar o mecanismo pelo qual se efetiva a floculação. Dentre as teorias destacam-se a da floculação coloidal, a hipótese das pontes de cálcio, a teoria das lectinas e o modelo simbiótico.

A teoria da floculação coloidal é baseada em princípios da ciência coloidal. Uma das importantes propriedades dos colóides para explicar a floculação é a tendência de agregação das partículas (Shaw, 1975). Kruyt (1952) observou para o fato de que pequenas partículas carregadas, em suspensão coloidal são precipitadas por sais inorgânicos, os quais neutralizam as cargas das partículas. As observações de Shaw e Kruyt contribuem para a explicação do fenômeno da floculação. Contudo este modelo não considera o requerimento específico por íons cálcio, o qual é apresentado por muitas linhagens de leveduras. Segundo Fisher (1975) esta teoria foi desacreditada quando observou-se que a neutralização das cargas da superficie das leveduras não resulta em floculação.

Do reconhecimento da importância do cálcio para a floculação surgiu a hipótese das pontes de cálcio. Este modelo fundamenta-se em princípios físico-químicos, propondo que íons cálcio bivalentes formem pontes entre os sítios receptores da superficie de duas células. Estas ligações são estabilizadas por pontes de hidrogênio, sendo sugerido que os grupos da superficie celular que interagem com o cálcio sejam carboxilas (Mill, 1964b) ou mesmo grupos fosfodiéster das mananas (Lyons \& Hough, 1970). Este modelo não considera efeitos específicos, como a inibição da floculação por açúcares simples (manose, maltose, sacarose ou glicose) ou por outros cátions, além do cálcio (Kihn et al., 1988; Stratford, 1992b).

A teoria das lectinas tenta explicar as lacunas deixadas pelas outras teorias. Propõe que ocorram ligações especificas entre a superficie das proteínas 
(lectinas) das células floculantes e resíduos de açúcares, mananas, que se encontram na parede celular. As lectinas são proteínas que se ligam a carboidratos com alto grau de especificidade (Boyd \& Shapleigh, 1954). As lectinas das leveduras podem reconhecer uma estrutura de carboidrato na superficie de outra célula e, dessa forma, se envolverem no processo de floculação (Miki et al, 1982).

O modelo simbiótico sugere a adesão entre diferentes tipos celulares, como por exemplo, de leveduras e outros microrganismos, geralmente bactérias (Harris \& Mitchell, 1973; Stratford, 1992a). Essa interação pode ser causada por substâncias floculantes, fimbrias e lectinas, e outros compostos.

\subsection{Fusão de protoplastos em leveduras}

Para aumentar a variabilidade dos microrganismos e proceder à seleção de linhagens melhor adaptadas faz-se o uso de dois métodos, principalmente: mutaçãoseleção e recombinação seguida de seleção.

A mutação-seleção se dá a partir de mutações espontâneas do tipo adaptativo, ou induzidos pela ação de agentes mutagênicos (Carrau, 1985). Consiste, no caso da indução, em avaliar uma população que sobreviveu ao tratamento com mutagênico e selecionar as colônias com melhor desempenho quanto ao caráter analisado. Segundo Fungaro (1990), esta metodologia tem resultado nos maiores avanços para melhoramento de caracteres qualitativos e quantitativos em microrganismos.

O método da recombinação consiste em hibridações nas quais os caracteres desejados têm uma combinação "dirigida" (Carrau, 1985). Estes híbridos, ou os recombinantes deles obtidos, são avaliados e selecionados. As hibridações podem ser realizadas por meio de cruzamentos sexuais (Zambonelli, 1964a, 1964b), fusão de protoplastos (Ferenczy et al, 1974; Anné \& Peberdy, 1976; Carrau et al., 1982) e pela tecnologia do DNA recombinante (Powell \& Kisttler, 1990; Hinchliffe \& Kenny, 1993).

A escolha do método para proceder a transferência do material genético vai depender das características biológicas das linhagens sob estudo. Fatores como tipo 
de mating type, incompatibilidade sexual e ciclo de vida, são fundamentais para esta escolha, assim como a natureza do caracter, se é qualitativo ou quantitativo (Fungaro, 1990).

A técnica de fusão de protoplastos é uma ferramenta muito útil no estudo da genética de vários microrganismos, principalmente nos que não apresentam fase sexual (Anné \& Peberdy, 1976). É de extrema valia na obtenção de híbridos e recombinantes entre linhagens que apresentam o mesmo mating type, incompatibilidade sexual ou mesmo híbridos e recombinantes interespecíficos ou intergenéricos, contribuindo, assim, para a produção de novos genótipos. Esta técnica permite a formação de heterocário entre hifas que normalmente não sofrem anastomose, auxiliando, desta forma, para o início "rápido" do ciclo parassexual ${ }^{14}$ (Anné \& Peberdy, 1976; Ferenczy, 1985) .

A literatura a respeito de fusão de protoplastos em leveduras é muito diversificada. Segundo revisão feita por Ferenczy (1985), as diferenças apresentadas nos protocolos de obtenção, regeneração e fusão de protoplastos são decorrentes de variações nos requerimentos utilizados, tais como: enzimas e seus aditivos, estabilizadores osmóticos e agentes fusionantes e seus aditivos. Há também variações quanto ao tempo de exposição à enzima. Esta diversidade aponta para a necessidade de adequação dos protocolos para cada linhagem a ser trabalhada.

Buscando o aperfeiçoamento do vinho de tradicionais regiões vinícolas do Brasil, Carrau et al. (1982) utilizaram a técnica de fusão de protoplastos. Os vinhos do sul do Brasil apresentam alta acidez em decorrência do excesso de ácido málico no mosto e para solucionar este problema, Carrau e colaboradores obtiveram, por fusão de protoplastos, uma linhagem híbrida intergenérica que apresenta a capacidade de Schizosaccharomyces pombe de decompor ácido L-málico e a taxa de crescimento de Saccharomyces cerevisiae. Para recuperar os produtos de fusão utilizaram dois processos. Um, no meio onde foram plaqueados os produtos de fusão a única fonte de

\footnotetext{
${ }^{14}$ Ciclo parassexual constitui numa forma alternativa de recombinação, onde não há a necessidade de um processso sexual com meiose, existe em alguns fungos e foi descrito pela primeira vez em Aspergillus nidulans, por Pontecorvo \& Roper em 1952 (Azevedo, 1972).
} 
carbono adicionada foi glicerol. Esta fonte só seria assimilada por Schizosaccharomyces pombe ou pelos fusionantes uma vez que as linhagens de Saccharomyces cerevisiae utilizadas não eram capazes de usar tal fonte de carbono. As colônias que cresceram neste meio foram transferidas para meio mínimo mais galactose, e como Schizosaccharomyces pombe não utiliza este açúcar, somente os resultados de fusão poderiam continuar seu desenvolvimento. No segundo processo, os fusionantes foram recuperados diretamente em meio mínimo mais galactose. Os produtos de fusão foram identificados pela morfologia típica das bordas das colônias de Schizosaccharomyces pombe.

Gupthar (1992) utilizou a fusão de protoplastos visando aumentar a tolerância ao etanol em Pichia stipitis e Candida shehatae. Foram obtidos fusionantes mononucleados, os quais se dissociaram em segregantes dos dois tipos parentais. $O$ autor observou que nenhum dos segregantes adquiriu maior tolerância ao etanol, mas constatou nos segregantes outras propriedades de Saccharomyces cerevisiae. Isto sugere que ocorreu transferência de genes antes da cariogamia ser desfeita.

$\mathrm{Na}$ tentativa de produzir etanol a partir de celulose num processo de estágio único, Anjani-Kumari \& Panda (1994) utilizaram híbridos intergenéricos obtidos pela fusão de protoplastos, de linhagens de Saccharomyces cerevisiae e Trichoderma reesei. De 201 fusionantes, 170 foram relativamente estáveis e dois demonstraram alta síntese de etanol a partir de celulose.

Em outros experimentos com fusão de protoplastos, Sulo et al. (1992), obtiveram a expressão do fenótipo killer de Saccharomyces cerevisiae em leveduras comerciais de vinho. A fusão foi interespecífica, utilizando linhagens de Saccharomyces cerevisiae e Saccharomyces oviformis. A qualidade dos vinhos resultantes da fermentação destes hibridos foi similar à qualidade dos vinhos obtidos a partir das linhagens parentais. Quanto ao fenótipo killer, sua estabilidade foi maior nas linhagens originais, mas sua atividade nos hibridos foi suficiente para suprimir linhagens indesejáveis.

Javadekar et al. (1995) também se valeram da fusão de protoplastos para construir uma linhagem de Saccharomyces cerevisiae altamente floculante associada 
ao caráter killer. Nessa fusão os protoplastos com o fenótipo killer foram mortos por exposição a luz ultravioleta enquanto que os protoplastos com a característica floculação foram mantidos vivos. Os fusionantes foram selecionados pela resistência a benomyl.

\subsection{Técnicas moleculares}

\subsubsection{Eletroforese em gel de campo pulsado (Pulsed-Field Gel Electrophoresis)}

Fragmentos de DNA de até $50 \mathrm{~kb}$ podem ser separados por eletroforese convencional em gel de agarose. Porém, para fragmentos maiores de $50 \mathrm{~kb}$ a $10 \mathrm{Mb}$, a aplicação de técnicas de eletroforese em gel de campo pulsado é mais apropriada. Esta técnica é indicada para separar as moléculas de DNA dos cromossomos de Saccharomyces cerevisiae, as quais apresentam aproximadamente $200 \mathrm{~kb}$ a $3 \mathrm{Mb}$. Segundo Johnston (1994), o genoma pode ser determinado pela separação dos cromossomos por esta técnica, resultando no chamado cariótipo eletroforético (Carle \& Olson, 1985).

Segundo Johnston (1994) por meio da PFGE as moléculas de DNA são separadas em géis de agarose pela aplicação de campos elétricos em diferentes direções. O tempo requerido pela molécula de DNA para mudar de direção, em resposta a uma troca na direção do campo elétrico, é diretamente proporcional ao seu tamanho.

Diferentes métodos de separação de cromossomos têm sido utilizados na identificação de leveduras. Carle \& Olson (1984), utilizando o método OrthogonalField-Alternation Gel Electrophoresis (OFAGE) verificaram a presença de 11 bandas cromossômicas bem definidas na levedura Saccharomyces cerevisiae. Em novo experimento verificaram que eram 12 bandas, das quais 9 eram bandas simples e 3 se mostraram bandas duplas, estabelecendo assim, cariótipo eletroforético para esta espécie, o qual apresenta um total de 15 cromossomos (Carle \& Olson, 1985).

Johnston \& Mortimer (1986) encontraram variações nos cariótipos eletroforéticos de diversas linhagens de Saccharomyces de uso comercial e de laboratório, assim como em leveduras de outras espécies, pelo método OFAGE. A 
observação mais intrigante foi a presença de somente 3 bandas cromossomais em Saccharomyces kluyveri, contra 14 em Saccharomyces carlsbergensis, $14 \mathrm{em}$ Saccharomyces uvarum e 17 em Saccharomyces bayanus. Com base nestes resultados os autores sugeriram a reclassificação de Saccharomyces kluyveri em outro gênero. Estes autores ainda constataram que as espécies Candida albicans, Candida utilis, Kluyveromyces lactis, Pichia (Hansenula) canadensis e Schwanniomyces occidentalis possuem um número pequeno de cromossomos, sendo todos maiores que $1000 \mathrm{~kb}$.

Os autores acima citados verificaram que a maioria das linhagens de leveduras de uso comercial (panificação, cervejaria, vinícola e destilaria) examinadas, deram um padrão de cariótipo eletroforético similar. Esses resultados reforçam as constatações de Gomes (1995), que encontrou grande similaridade nos padrões de cariótipo eletroforético das linhagens da indústria alcooleira, obtidos pelo método Contour-Clamped Homogeneous Electric Field (CHEF). Por outro lado, contrapõem-se aos resultados obtidos por Gomes (1995) para as linhagens da indústria cervejeira, onde verificou ampla variação nos padrões de cariótipo eletroforético, utilizando o método CHEF.

Jonge et al. (1986) estabeleceram padrões de bandas de DNA de leveduras pelo método OFAGE. Constataram que ocorriam variações no número de bandas e suas posições no gel entre leveduras de gêneros diferentes, do mesmo gênero e até mesmo entre linhagens da mesma espécie.

O método Field Inversion Gel Electrophoresis (FIGE) melhora a resolução de cromossomos maiores (com mais de $1000 \mathrm{~kb}$ ). Johnston et al. (1988) utilizaram este método para separar os grandes cromossomos de Saccharomyces cerevisiae e de outros gêneros de levedura. Por este método puderam observar a presença de 5 bandas cromossomais em Saccharomyces kluyveri, contra 3 observadas pelo método OFAGE.

Leveduras vinícolas foram diferenciadas $\mathrm{e}$ identificadas pela combinação de métodos bioquímicos rápidos, perfil killer, perfil da eletroforese de proteínas, perfil de ácidos graxos voláteis e cariótipo eletroforético. Pelos dados obtidos 
pelo FIGE não foi possivel tirar conclusões sobre a identidade de 3 linhagens, das 9 investigadas, mas foi possível constatar que as 3 não eram idênticas (Degré et al., 1989).

A técnica de Transverse Alternating Field Electrophoresis (TAFE) foi proposta para realizar a identificação e controle de linhagens de leveduras do vinho. Segundo Vezinhet et al. (1990), de 22 linhagens investigadas somente 3, que tinham origem no mesmo parreiral, não foram diferenciadas por esta técnica. Durante 6 anos consecutivos foi realizado um estudo da ecologia de linhagens de Saccharomyces cerevisiae em dois vinhedos. As linhagens identificadas apresentaram uma grande diversidade nos padrões moleculares obtidos por TAFE e restrição de DNA mitocondrial.

Basso et al. (1992) avaliaram a potencialidade da técnica de cariotipagem do DNA cromossômico, para monitorar a permanência de leveduras melhoradas, em escala industrial. Além disso, Basso et al. (1995) utilizaram o método TAFE com a finalidade de acompanhar a estabilidade de diferentes leveduras industriais e isolar as linhagens que manifestassem dominância e/ou persistência no processo fermentativo em várias destilarias.

Frezier \& Dubourdieu (1992) utilizaram o método CHEF para estudar a ecologia das linhagens selvagens de Saccharomyces cerevisiae durante a fermentação espontânea de vinho tinto Bordeaux. Constataram que um número reduzido de linhagens foram capazes de dominar a fermentação alcoólica em todos os tonéis da mesma vinícola, independentemente do cultivar de parreira ou da época da colheita. Este mesmo método foi utilizado por Sheehan et al. (1991) para identificação de leveduras de cervejaria.

A metodologia do cariótipo eletroforético CHEF foi utilizada com sucesso para auxiliar na identificação de leveduras do grupo stricto sensu do gênero Saccharomyces. Neste gênero a taxonomia convencional muitas vezes torna-se difícil de ser analisada (Naumov et al., 1992; Cardinali \& Martini, 1994).

Spencer et al. (1992) utilizaram a metodologia FIGE para observar mudanças de mobilidade dos cromossomos de híbridos. Esses híbridos resultaram da tentativa de transferir genes de outras linhagens de leveduras para linhagens de Saccharomyces cerevisiae de uso industrial, com o auxilio de uma linhagem haplóide e kar1-1 como vetor. Estes autores puderam constatar, pelos resultados obtidos, que 
provavelmente tenha ocorrido a transferência de um cromossomo simples, primeiro, do doador para a linhagem vetor e desta para a linhagem industrial. A transferência dos genes foi provavelmente consumada pela formação de linhagens dissômicas e no caso dos híbridos que metabolizavam amido, a transferência se deu pela integração do gene sta2 no genoma da linhagem industrial.

Híbridos obtidos por fusão de protoplastos entre Pachysolen tannophilus e Saccharomyces cerevisiae foram caracterizados com o auxilio de cariótipo eletroforético. Foi constatado que os genes para a utilização da xilose foram transferidos de Pachysolen tannophilus para Saccharomyces cerevisiae, mas os híbridos assemelhamse ao parental Saccharomyces cerevisiae quanto a morfologia e a assimilação de açúcar. Pela eletroforese de campo pulsado FIGE foi demonstrado que o padrão de bandas era intermediária entre as duas espécies parentais (Heluane et al., 1993).

\subsubsection{Polimorfismo de DNA amplificado ao acaso - (Random Amplified Polimorphic DNA - RAPD)}

A análise genética de qualquer espécie exige marcadores bem definidos e facilmente reconhecíveis. A utilização de marcadores morfológicos, auxotróficos e resistentes tem auxiliado na elaboração de mapas genéticos de alguns microrganismos (Varga \& Croft, 1994), mas tipos especiais de marcadores moleculares, como o RAPD, tem permitido a análise genética de espécies que não possuem ciclo sexual (Williams et al., 1990)

A deteç̧ão e a análise dos polimorfismos presentes na seqüência do DNA, representam um dos mais significativos avanços da biologia molecular. Esta forma de polimorfismo representa uma classe específica de marcador molecular e foi descrita simultaneamente por Williams et al. (1990) sob a denominação Random Amplified Polymorphic DNA (RAPD) e por Welsh \& McClelland (1990) com a denominação fingerprinting Arbitrary Primed Polymerase Chain Reaction (AP-PCR).

Esta técnica é baseada na amplificação de fragmentos não específicos de DNA repetitivos. Utiliza-se oligonucleotídios de 10 a 15 bases (primers), de seqüência 
arbitrária, para iniciar a amplificação do DNA genômico, utilizando a reação de polimerase em cadeia (PCR). Os polimorfismos visualizados em géis de agarose corados com brometo de etídio são denominados marcadores RAPDs (Williams et al. 1990).

Segundo os últimos autores os marcadores RAPDs são dominantes. Isto porque os polimorfismos são identificados pela presença de um fragmento específico de DNA amplificado em um dos genótipos em relação a ausência deste mesmo fragmento em outro genótipo.

As principais aplicações dos marcadores RAPDs são: o fingerprinting (Welsh \& McClelland, 1990), o mapeamento genético (Reiter et al., 1992) e a tipagem molecular de genótipos e espécies, incluindo a caracterização de híbridos somáticos do ciclo parassexual (Durand et al., 1993).

O RAPD é uma técnica muito sensível à diferença de nucleotídios entre o oligonucleotídio e o molde de DNA, incluindo diferenças em um único nucleotídio. $\mathrm{O}$ RAPD tem sido amplamente utilizado por ser tecnicamente simples, rápido e confiável e por não necessitar de sondas radioativas. Além disso, requer DNA em pequena quantidade e não necessariamente de alta qualidade (Manulis et al., 1994).

Os primeiros a utilizar marcadores RAPDs para a análise de segregantes e elaboração de mapa genético foram Williams et al. (1990). Fizeram uso destes marcadores na soja e os resultados por eles obtidos foram confirmados por marcadores RFLPs (Restriction Fragment Length Polymorphism).

Quesada \& Cenis (1995) avaliaram a utilização do RAPD na caracterização de leveduras de vinho. Foram estabelecidas diferenciações entre gêneros e espécies e ainda entre 12 linhagens de Saccharomyces cerevisiae. O nível de polimorfismo detectado foi relativamente baixo. Uma vez que os padrões de amplificação do gênero foram muito parecidos e uma única reação, com um único primer não foi capaz de distinguir as linhagens sob estudo, os autores sugeriram o uso de informações de diversas reações.

O RAPD e PCR foram comparados para a identificação de leveduras deterioradoras de alimentos (Couto et al., 1995). Os autores concluíram que ambas as 
técnicas são ferramentas adequadas para a identificação destas leveduras, apesar do RAPD apresentar padrões menos estáveis que a PCR.

Vlugt-Bergmans et al. (1993) investigaram a segregação das marcas polimórficas geradas por RAPD. Para este estudo utilizaram a progênie derivada do cruzamento de duas linhagens de Botrytis cinerea que apresentaram coeficiente de similaridade 0,99. Constataram que a maioria dos marcadores RAPDs testados segregaram numa taxa mendeliana normal de 1:1, apesar de ter sido observada uma taxa de 1:0 para dois marcadores, o que poderia ser explicado pela ocorrência de um loco homozigoto se o fungo fosse diplóide. Verificaram ainda que 3 marcadores presentes em um dos parentais foi ausente na progênie e 2 marcadores que não foram constatados nos parentais segregaram numa taxa de 1:1 na progênie.

Marcadores RAPDs foram utilizados na confirmação dos supostos heterocários formados em Rhizoctonia solani. Os resultados deste estudos demonstraram que a formação de tufos nem sempre é indicativo de heterocariotização e sugerem uma limitada migração nuclear durante o mating nesta espécie (Cubeta et al. 1993).

Outros autores que empregaram marcadores RAPDs para estudo de hibridos e segregantes foram Francis \& Clair (1993). Esses autores fizeram a seleção, pelo uso de marcadores RAPDs, da progênie de oósporos para identificar híbridos potenciais entre dois parentais de Pythium ultimum. Após uma auto fecundação produziu-se uma população $F_{2}$, a qual demonstrou segregação e arranjo independente de marcadores RAPD e RFLP.

Durand et al. (1993) usaram RAPDs como um sistema de marcas genéticas para caracterizar linhagens recombinantes oriundas de um ciclo parassexual de Penicillium roqueforti. Após fusão de protoplastos e haploidização dos hibridos diplóides, os segregantes foram caracterizados pelo rearranjo dos marcadores parentais. Os autores verificaram que a maioria dos recombinantes exibiu o perfil de uma das linhagens parentais, embora novos produtos tenham sido gerados. Os novos perfis desses recombinantes derivaram da presença de novos fragmentos amplificados, bem como da ausência de bandas características aos parentais. Isso demonstra que a recombinação pode destruir um sítio de ligação, assim como produzir um novo sítio, o que permite a 
amplificação de outro produto diferente. Esse rearranjo pode ser conseqüência de um crossing over ou de uma translocação. Outra causa da perda de sítios de ligação pode ser em decorrência da destruição de um par dos sítios de ligação por rearranjo cromossômico, isto é, pode surgir da não disjunção durante a haploidização.

Varga \& Croft (1994) realizaram fusão de protoplasto interespecifico entre Aspergillus nidulans e Aspergillus quadrilineatus. Os segregantes obtidos da linhagem híbrida possuíam todos os cromossomos de Aspergillus nidulans, com exceção de um deles, o qual foi substituído pelo cromossomo equivalente de Aspergillus quadrilineatus. Os segregantes foram analisados por isoenzimas, RFLPs e RAPDs e regiões amplificadas foram mapeadas. 


\section{MATERIAL E MÉTODOS}

\subsection{Material biológico}

Neste trabalho foram utilizadas duas linhagens de leveduras classificadas como Saccharomyces cerevisiae. Uma apresenta a característica $\mathrm{H}_{2} \mathrm{~S}^{-}$e foi obtida da micoteca do Departamento de Ciência e Tecnologia Agroindustrial da Escola Superior de Agricultura "Luiz de Queiroz"/USP, identificada por IZ 987. A outra, ABXR.11B, é floculante e foi cedida pelo Laboratório de Genética de Leveduras do Departamento de Genética da Escola Superior de Agricultura "Luiz de Queiroz"/USP.

A linhagem IZ 987 já foi utilizada por Ribeiro (1997), que constatou que a referida linhagem produz álcool de forma satisfatória, sendo a aguardente produzida pela fermentação da cana-de-açúcar, por esta linhagem, de boa qualidade. $O$ autor constatou que a linhagem não produzia $\mathrm{H}_{2} \mathrm{~S}$.

A linhagem ABXR.11B já foi utilizada pelo Laboratório de Genética de Leveduras da Escola Superior de Agricultura "Luiz de Queiroz" para experimentos onde se fazia necessário o carácter "altamente floculante".

A título de ilustração, a Figura 5 mostra a formação de flóculos pela linhagem ABXR.11B e a Figura 6 mostra as características celulares da linhagem IZ 987, quando ambas as linhagens foram cultivadas em meio YEPD e observadas ao microscópio ótico a fresco. 


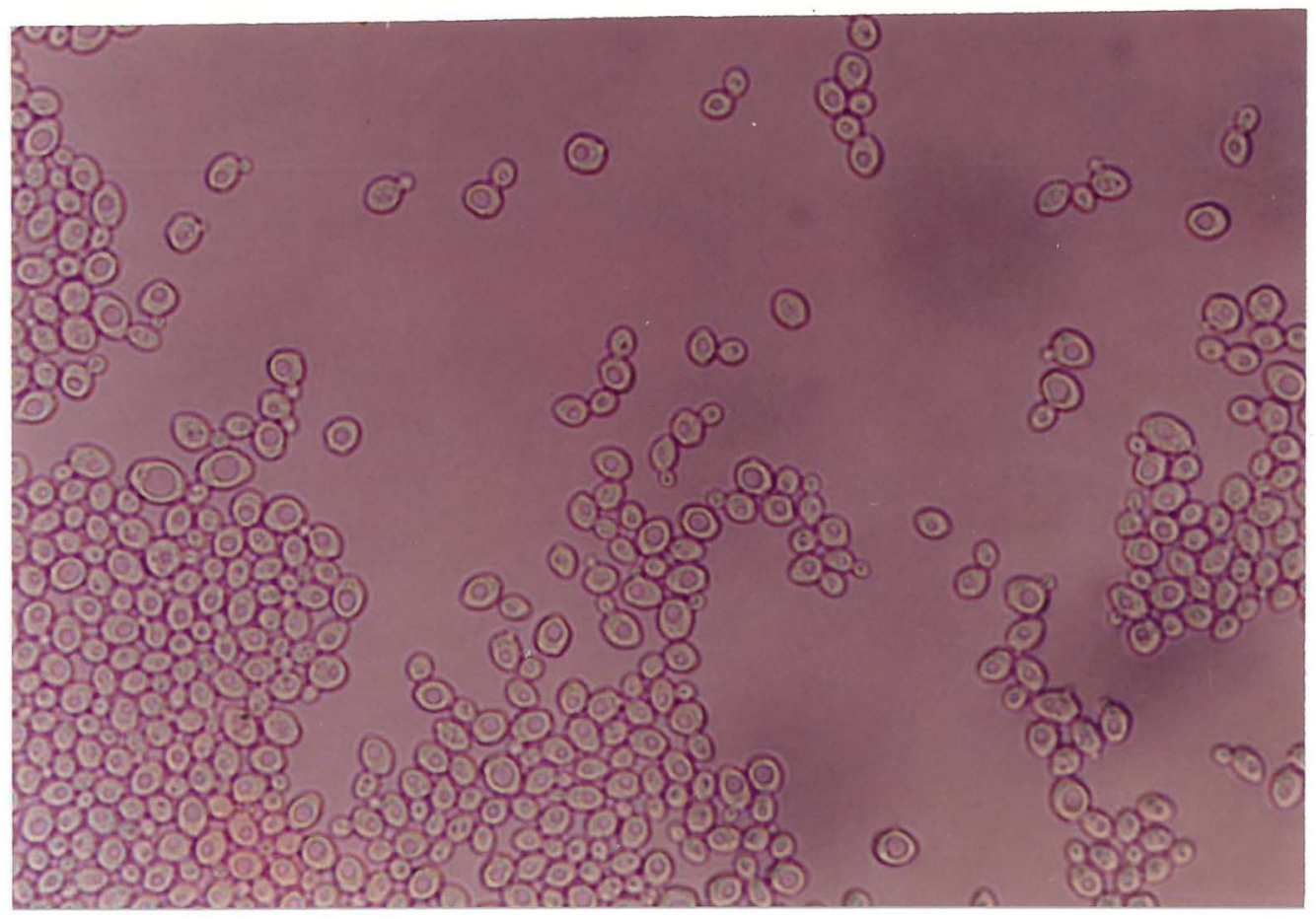

Figura 5 - Linhagem ABXR.11B: flóculo formado pela agregação de células, quando cultivada em meio YEPD. (Aumento $400 \mathrm{X}$ );

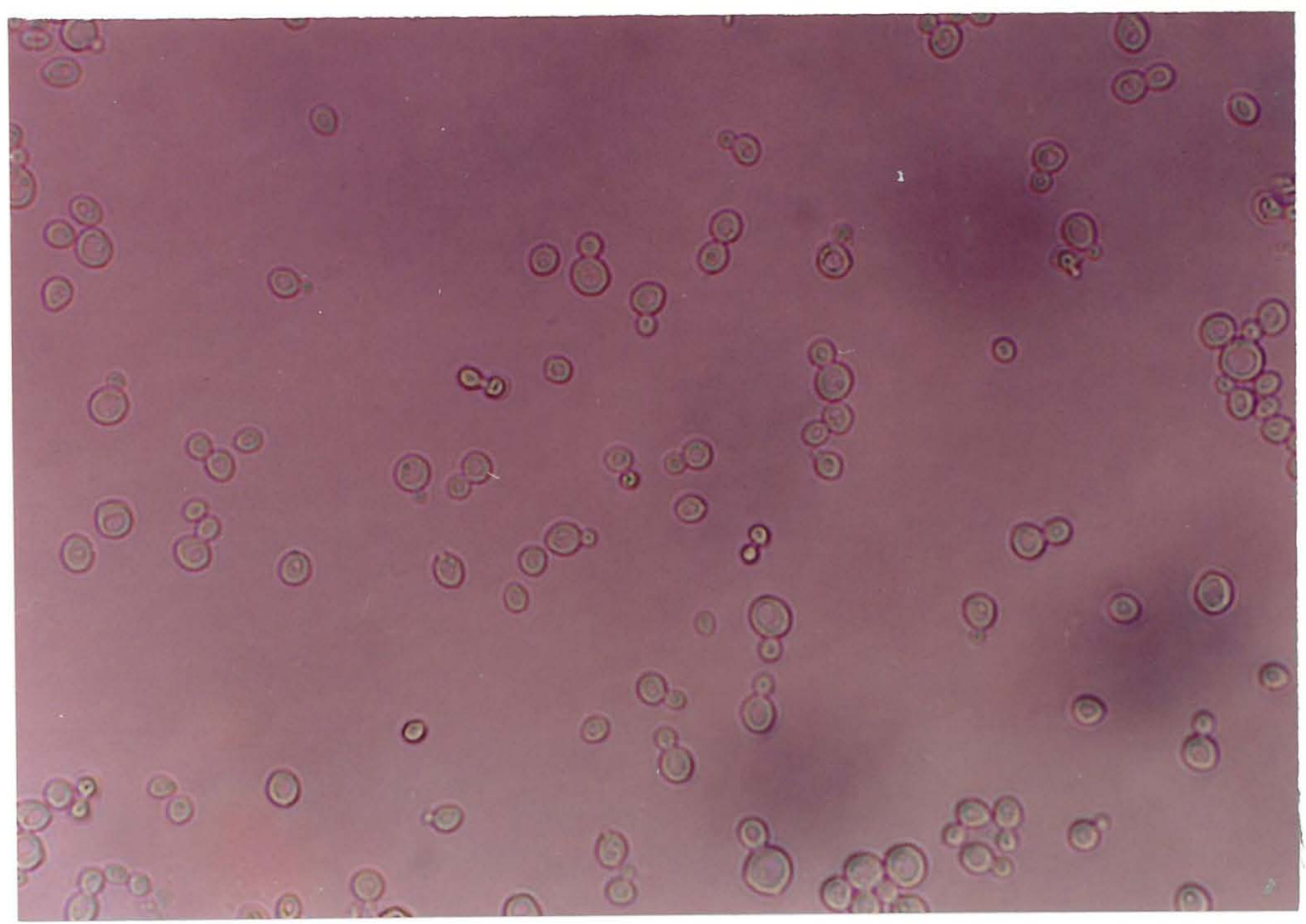

Figura 6 - Linhagem IZ 987: características celulares, quando cultivada em YEPD. (Aumento $400 \mathrm{X}$ ). 


\subsection{Meios de cultura}

De forma geral os meios de cultura foram esterilizados em autoclave, a $121^{\circ} \mathrm{C}$, a $1 \mathrm{~atm}$ por 20 minutos.

\subsubsection{Meio YEPD (Mortimer \& Hawthorne, 1969)}

$\begin{array}{lr}\text { Extrato de levedura } & 10 \mathrm{~g} \\ \text { Peptona } & 20 \mathrm{~g} \\ \text { Glicose } & 20 \mathrm{~g} \\ \text { Água destilada } & 1000 \mathrm{~mL}\end{array}$

Para o preparo do meio sólido, $15 \mathrm{~g}$ de ágar foram adicionados. $\mathrm{O} \mathrm{pH}$ não foi ajustado.

Este meio foi utilizado para a manutenção de culturas, para crescimento, para testes de estabilidade e para isolamento de segregantes.

3.2.2. Meio mínimo (Reaume \& Tatum, modificado por Fungaro \& PizziraniKleiner, 1992)

$\begin{array}{lr}\text { Glicose } & 20,00 \mathrm{~g} \\ \text { Asparagina } & 2,00 \mathrm{~g} \\ \mathrm{KH}_{2} \mathrm{PO}_{4} & 1,50 \mathrm{~g} \\ \mathrm{MgSO}_{4} \cdot 7 \mathrm{H}_{2} \mathrm{O} & 0,50 \mathrm{~g} \\ \mathrm{CaCl}_{2} \cdot 2 \mathrm{H}_{2} \mathrm{O} & 0,30 \mathrm{~g} \\ \left(\mathrm{NH}_{4}\right)_{2} \mathrm{SO}_{4} & 2,00 \mathrm{~g} \\ \mathrm{KI} & 100,00 \mathrm{mg} \\ \text { Pantotenato de cálcio } & 1,00 \mathrm{mg} \\ \text { Inositol } & 1,00 \mathrm{mg} \\ \mathrm{MnSO}_{4} & 0,02 \mathrm{mg} \\ \mathrm{ZnSO}_{4} & 2,00 \mathrm{mg} \\ \mathrm{CuSO}_{4} & 0,10 \mathrm{mg} \\ \mathrm{Na}_{2} \mathrm{~B}_{4} \mathrm{O}_{7} \cdot 10 \mathrm{H}_{2} \mathrm{O} & 0,01 \mathrm{mg} \\ \left(\mathrm{NH}_{4}\right)_{6} \mathrm{Mo}_{7} \mathrm{O}_{24} \cdot 4 \mathrm{H}_{2} \mathrm{O} & 0,02 \mathrm{mg}\end{array}$


$\mathrm{FeSO}_{4}$

$0,20 \mathrm{mg}$

Ágar

$15,00 \mathrm{~g}$

Água destilada

$1000,00 \mathrm{~mL}$

$\mathrm{O} \mathrm{pH}$ foi ajustado para $6,8 \mathrm{com} \mathrm{NaOH} 1 \mathrm{~N}$ ou $\mathrm{HCl} 1 \mathrm{~N}$. Este meio foi utilizado no isolamento e caracterização dos mutantes auxotróficos.

Para a caracterização dos mutantes auxotróficos, este meio foi acrescido de $0,1 \mathrm{~mL}$ por placa $(20 \mathrm{~mL}$ de meio) de soluções de requerimentos nutricionais adequados, conforme Tabela 2, item 3.3.5.

\subsubsection{Meio BSA (Bismuth sulfite agar desidratado - DIFCO)}

BSA

Água deionizada
$52 \mathrm{~g}$

$1000 \mathrm{~mL}$

Após ser reidratado o meio foi aquecido até a fervura para dissolver, por no máximo 2 minutos.

Este meio foi utilizado para determinação qualitativa do caráter $\mathrm{H}_{2} \mathrm{~S}$.

\subsubsection{Meio YEPD de regeneração}

Este meio foi preparado como descrito no item 3.2.1 e a estabilidade osmótica foi obtida pela adição de $1,2 \mathrm{M}$ de sorbitol. O presente meio foi utilizado na regeneração de protoplastos em experimento para determinar a porcentagem de protoplastização, de regeneração e na fusão propriamente dita.

\subsubsection{Meio mínimo de regeneração}

Este meio foi preparado segundo descrição no item 3.2.2. e a estabilidade osmótica foi obtida pela adição de $1,2 \mathrm{M}$ de sorbitol. $\mathrm{O} \mathrm{pH}$ foi ajustado para 6,8 com $\mathrm{NaOH} 1 \mathrm{~N}$. Este meio foi utilizado na seleção de híbridos obtidos por fusão de protoplasto. 


\subsubsection{Meio de esporulação - Rafinose Acetato (RA)}

Solução A: Rafinose $\quad 2,2 \%$

Solução B: Acetato de potássio $\quad 20 \%$

Um mililitro da solução $\mathrm{A}$ e $1 \mathrm{~mL}$ da solução $\mathrm{B}$ foram misturados e o volume ajustado para $200 \mathrm{~mL}$ com água destilada. A este foram adicionados $4 \mathrm{~g}$ de ágar. Este meio foi utilizado na tentativa de obter segregantes dos produtos de fusão.

\subsection{Soluções e tampões}

\subsubsection{Solução salina $(0,85 \%)$}

$\begin{array}{lc}\mathrm{NaCl} & 8,5 \mathrm{~g} \\ \text { Água destilada } & 1000 \mathrm{~mL}\end{array}$

A solução foi acondicionada em frasco com 10 e $9 \mathrm{~mL}$, autoclavada a $120^{\circ} \mathrm{C}$ por 20 minutos e conservada em refrigerador. Foi utilizada para fazer suspensões celulares e diluições.

\subsubsection{Solução de vitaminas}

$\begin{array}{lr}\text { Ácido nicotínico } & 100,0 \mathrm{mg} \\ \text { Ácido p-aminobenzóico } & 10,0 \mathrm{mg} \\ \text { Biotina } & 0,2 \mathrm{mg} \\ \text { Piridoxina } & 50,0 \mathrm{mg} \\ \text { Riboflavina } & 100,0 \mathrm{mg} \\ \text { Tiamina } & 50,0 \mathrm{mg} \\ \text { Água destilada estéril } & 100,0 \mathrm{~mL}\end{array}$

A solução foi aquecida em banho-maria a $98^{\circ} \mathrm{C}$ por 20 minutos e mantida em frasco escuro, sob refrigeração. 


\subsubsection{Solução de ácidos nucléicos de leveduras}

Solução A: $2 \mathrm{~g}$ de ácidos nucléicos de leveduras diluídas em $15 \mathrm{~mL}$ de $\mathrm{HCl} 1 \mathrm{~N}$

Solução B: $2 \mathrm{~g}$ de ácidos nucléicos de leveduras diluídas em $15 \mathrm{~mL}$ de $\mathrm{NaOH} 1 \mathrm{~N}$.

Ambas as soluções foram aquecidas em banho-maria a $98^{\circ} \mathrm{C}$ por 20 minutos. Em seguida foram misturadas em igual proporção e o $\mathrm{pH}$ foi ajustado para 6,0 com $\mathrm{NaOH} 4 \%$. O volume foi completado para $40 \mathrm{~mL}$ com água destilada esterilizada. A solução final, foi aquecida em banho-maria a $98^{\circ} \mathrm{C}$ por 20 minutos e mantida em frasco escuro, sob refrigeração.

\subsubsection{Solução de caseína hidrolisada}

Caseína hidrolisada $100 \mathrm{mg}$

Água destilada esterilizada

$10 \mathrm{~mL}$

A solução foi aquecida em banho-maria a $98^{\circ} \mathrm{C}$ por 20 minutos e conservada em refrigerador.

\subsubsection{Solução de requesitos nutricionais}

Estes suplementos, foram preparados diluindo-se cada um deles em frascos contendo $10 \mathrm{~mL}$ de água destilada estéril, nas quantidades discriminadas na Tabela 2. Posteriormente, estas soluções foram aquecidas em banho-maria a $98^{\circ} \mathrm{C}$ por 20 minutos e conservadas em refrigerador. 
Tabela 2 - Requisitos nutricionais e respectivasqquantidades diluídas em $10 \mathrm{~mL}$ de água.

Tiossulfato $200,0 \mathrm{mg}$

Prolina, arginina, lisina, triptofano, metionina, histidina, isoleucina, glutamina, homoserina, treonina, cisteína, fenilalanina, tirosina, alanina e valina $100,0 \mathrm{mg}$ Adenina, uracila, guanina, citosina e timina $50,0 \mathrm{mg}$

Tiamina, riboflavina, ácido nicotínico $1,0 \mathrm{mg}$ Ácido p-aminobenzóico, piridoxina $0,5 \mathrm{mg}$ Biotina $0,2 \mathrm{mg}$

\subsubsection{Solução tampão fosfato sorbitol (TSP 1 M)}

Solução A: $0,2 \mathrm{M} \mathrm{Na}_{2} \mathrm{HPO}_{4}$

$210 \mathrm{~mL}$

Solução B: $0,2 \mathrm{M} \mathrm{NaH}_{2} \mathrm{PO}_{4}$

$40 \mathrm{~mL}$

Sorbitol

$91 \mathrm{~g}$

As soluções A e B foram misturadas e o volume foi levado até $450 \mathrm{~mL}$ com $\mathrm{H}_{2} \mathrm{O}$ destilada e o $\mathrm{pH}$ foi acertado para 7,5 com uma das soluções. Após adição do sorbitol o volume foi finalmente completado para $500 \mathrm{~mL}$.

$$
\begin{array}{cc}
\text { Solução A: } 0,2 \mathrm{M} \mathrm{Na}_{2} \mathrm{HPO}_{4} & 28,39 \mathrm{~g} \\
\text { Água destilada } & 1000 \mathrm{~mL} \\
\text { Solução B: } 0,2 \mathrm{M} \mathrm{NaH}_{2} \mathrm{PO}_{4} & 5,52 \mathrm{~g} \\
\text { Água destilada } & 200 \mathrm{~mL}
\end{array}
$$

As soluções A e B foram conservadas em refrigerador e o tampão foi preparado fresco.

\subsubsection{Solução de EDTA $10 \mathrm{mM}$}

EDTA.Na ${ }_{2}$ (Etilenodiaminotetracetato de sódio)

$$
\text { EDTA.Na }{ }_{2}
$$$$
3,7225 \mathrm{~g}
$$

Água destilada

$$
1000 \mathrm{~mL}
$$


$\mathrm{O}$ pH foi ajustado com pastilhas de $\mathrm{NaOH}$ e a solução foi autoclavada e mantida em temperatura ambiente.

\subsubsection{Solução enzimática para obtenção de protoplastos}

Novozym 234 (Batch ppm 3897) $200 \mathrm{mg}$

Água destilada esterilizada $\quad 2 \mathrm{~mL}$

A solução foi mantida em frasco escuro em congelador.

3.3.9. Solução de cloreto de cálcio $(1,2 \mathrm{M})$

$\mathrm{CaCl}_{2}$

Água destilada

$$
6,6528 \mathrm{~g}
$$$$
50,0 \mathrm{~mL}
$$

A solução foi autoclavada e mantida em temperatura ambiente.

\subsubsection{Solução fusogênica (PEG $40 \%$ )}

$\begin{array}{lc}\text { PEG (Polietilenoglicol) } & 2 \mathrm{~g} \\ \mathrm{CaCl}_{2} .2 \mathrm{H}_{2} \mathrm{O} & 5,5 \mathrm{mg} \\ \text { TSP } & 5 \mathrm{~mL}\end{array}$

A solução foi autoclavada e mantida no refrigerador.

\subsubsection{Agarose LGT (low gelling temperature) - Sigma - 1,4\%}

Agarose LMP $\quad 1,4 \mathrm{~g}$

EDTA.Na ${ }_{2}(\mathrm{PM}=372,2) 0,05 \mathrm{M} . \quad 100 \mathrm{~mL}$

A agarose foi preparada no momento do uso.

\subsubsection{Tampão NDS}

$\begin{array}{lc}\text { Tris-HCl } 0,5 \mathrm{M} \mathrm{pH} 8,0 & 2 \mathrm{~mL} \\ \text { EDTA.Na } 2 \text { 0,5 M pH 8,0 } & 90 \mathrm{~mL} \\ \text { SDS (N laurylsarcosinato de sódio) } & 1 \mathrm{~g}\end{array}$


O tampão foi preparado no momento do uso, sendo o volume completado até $100 \mathrm{~mL}$ com água deionizada. A proteinase $\mathrm{K}$ foi adicionada a fresco, na concentração de $1 \mathrm{mg} / \mathrm{mL}$, de acordo com a quantidade de NDS requerido e preparado.

\subsubsection{Agarose para pulsed field $1 \%$ (Sigma A)}

Agarose para gel de corrida de pulsed field

$1 \mathrm{~g}$

TBE 1X

$100 \mathrm{~mL}$

A agarose foi colocada em frasco erlenmeyer e adicionado o respectivo tampão, foram pesados e em seguida foram levados ao forno de microondas e aquecidos até a fervura para a completa dissolução da agarose. Após a dissolução da agarose foi acrescentado água Milli $Q$ até alcançar o valor previamente pesado.

\subsubsection{Tampão Tris-HCl $1 \mathrm{M}$ pH 8,0}

Trizma base $-(\mathrm{PM}=121,1)$

(Tris [hidroximetil] amino metano) $121,1 \mathrm{~g}$

Água deionizada $\quad 1000 \mathrm{~mL}$

A Trizma base foi dissolvida em aproximadamente $800 \mathrm{~mL}$ de água deionizada e seu $\mathrm{pH}$ foi ajustado para 8,0 com $\mathrm{HCl} 1 \mathrm{~N}$ e então o volume final foi completado para $1000 \mathrm{~mL}$. A solução foi autoclavada e guardada em temperatura ambiente.

\subsubsection{Tampão de corrida TBE $10 \mathrm{X}$ concentrado}

$\begin{array}{lc}\text { Trizma base } & 54,0 \mathrm{~g} \\ \text { Ácido bórico }(\mathrm{PM}=61,83) & 27,5 \mathrm{~g} \\ \text { EDTA.Na }_{2} 0,5 \mathrm{M} \mathrm{pH} \mathrm{8,0} & 20,0 \mathrm{~mL} \\ \mathrm{H}_{2} \mathrm{O} & 500,0 \mathrm{~mL}\end{array}$

A solução foi autoclavada e guardada em temperatura ambiente. No momento do uso foi feita a diluição necessária com água Milli Q. 
3.3.16. Solução de EDTA 0,05 M pH 8,0 =

$\begin{array}{lr}\text { EDTA. } \mathrm{Na}_{2} & 3,722 \mathrm{~g} \\ \mathrm{H}_{2} \mathrm{O} & 200,0 \mathrm{~mL} \\ \mathrm{O} \text { pH foi ajustado com pastilhas de } \mathrm{NaOH} .\end{array}$

3.3.17. Solução estoque de brometo de etídio

Foi dissolvido $1,0 \%(\mathrm{p} / \mathrm{v})$ de brometo de etídio em água destilada, agitado por várias horas e estocado à temperatura ambiente. No momento do uso $3 \mu \mathrm{L}$ desta solução foram adicionados à $100 \mathrm{~mL}$ de $\mathrm{H}_{2} \mathrm{O}$ ou tampão TBE 0,5 ou $1 \mathrm{X}$.

\subsubsection{Solução de SDS $10 \%$}

$\begin{array}{lc}\text { N laurylsarcosinato de sódio } & 10 \mathrm{~g} \\ \mathrm{H}_{2} \mathrm{O} & 200 \mathrm{~mL}\end{array}$

A solução foi autoclavada e deixada em temperatura ambiente.

\subsubsection{Clorofane}

Fenol

Clorofórmio

Álcool Isoamilico
$25 \mathrm{~mL}$ $24 \mathrm{~mL}$

$1 \mathrm{~mL}$

A solução foi mantida em frasco escuro e sob refrigeração. No momento do uso foi utilizada a fração inferior.

3.3.20. Clorofil

Clorofórmio $24 \mathrm{~mL}$

Álcool Isoamilico

$1 \mathrm{~mL}$

A solução foi mantida em frasco escuro e sob refrigeração.

3.3.21. Solução de acetato de sódio $3 \mathrm{M}$, pH 4,8

Acetato de sódio

$\mathrm{H}_{2} \mathrm{O}$
$40,82 \mathrm{~g}$

$100 \mathrm{~mL}$ 
3.3.22. Tampão TE (Tris-EDTA)

Tris-EDTA $(\mathrm{pH} 7,6)$

$10 \mathrm{mM}$

EDTA.Na $2(\mathrm{pH} 8,0)$

$1 \mathrm{mM}$

\subsubsection{Agarose $0,8 \%$}

$\begin{array}{lc}\text { Agarose } & 0,8 \mathrm{~g} \\ \text { Tampão TBE 1X } & 100 \mathrm{~mL}\end{array}$

A agarose foi preparada conforme o item 3.3.12.

\subsubsection{Agarose $1,3 \%$}

$\begin{array}{lr}\text { Agarose } & 1,3 \mathrm{~g} \\ \text { Tampão TBE 1X } & 100 \mathrm{~mL}\end{array}$

A agarose foi preparada conforme o item 3.3.12.

\subsection{Teste de potencial para produção de $\mathrm{H}_{2} \mathrm{~S}$}

Para analisar a capacidade de produção de $\mathrm{H}_{2} \mathrm{~S}$ foi utilizado o método proposto por Nickerson (1953) para detecção de redução de sulfito em Candida. Este método foi utilizado por Zambonelli (1964a) para identificação de linhagens de Saccharomyces cerevisiae deficientes na atividade da enzima sulfito redutase e mais recentemente foi validado como uma metodologia rápida para a seleção de linhagens $\mathrm{H}_{2} \mathrm{~S}$ para uso vinícola (Jiranek, et al. 1995b).

O método consiste na transferência das linhagens por meio de estrias para meio Bismuth Sulfite Agar (Difco - item 3.2.3) e incubadas por 24/48 horas em BOD, a $28^{\circ} \mathrm{C}$. Após este periodo as estrias foram observadas quanto a coloração. As estrias que resultaram na cor branca foram identificadas como sendo de linhagens $\mathrm{H}_{2} \mathrm{~S}^{-}$e as estrias pretas ou enegrecidas, de linhagens $\mathrm{H}_{2} \mathrm{~S}^{+}$. A titulo de ilustração, a Figura 7 apresenta uma linhagem de levedura produtora de $\mathrm{H}_{2} \mathrm{~S}$ e outra não produtora, inoculadas, sob a forma de estrias, no meio BSA após 24 horas de incubação em BOD, a $28^{\circ} \mathrm{C}$. 


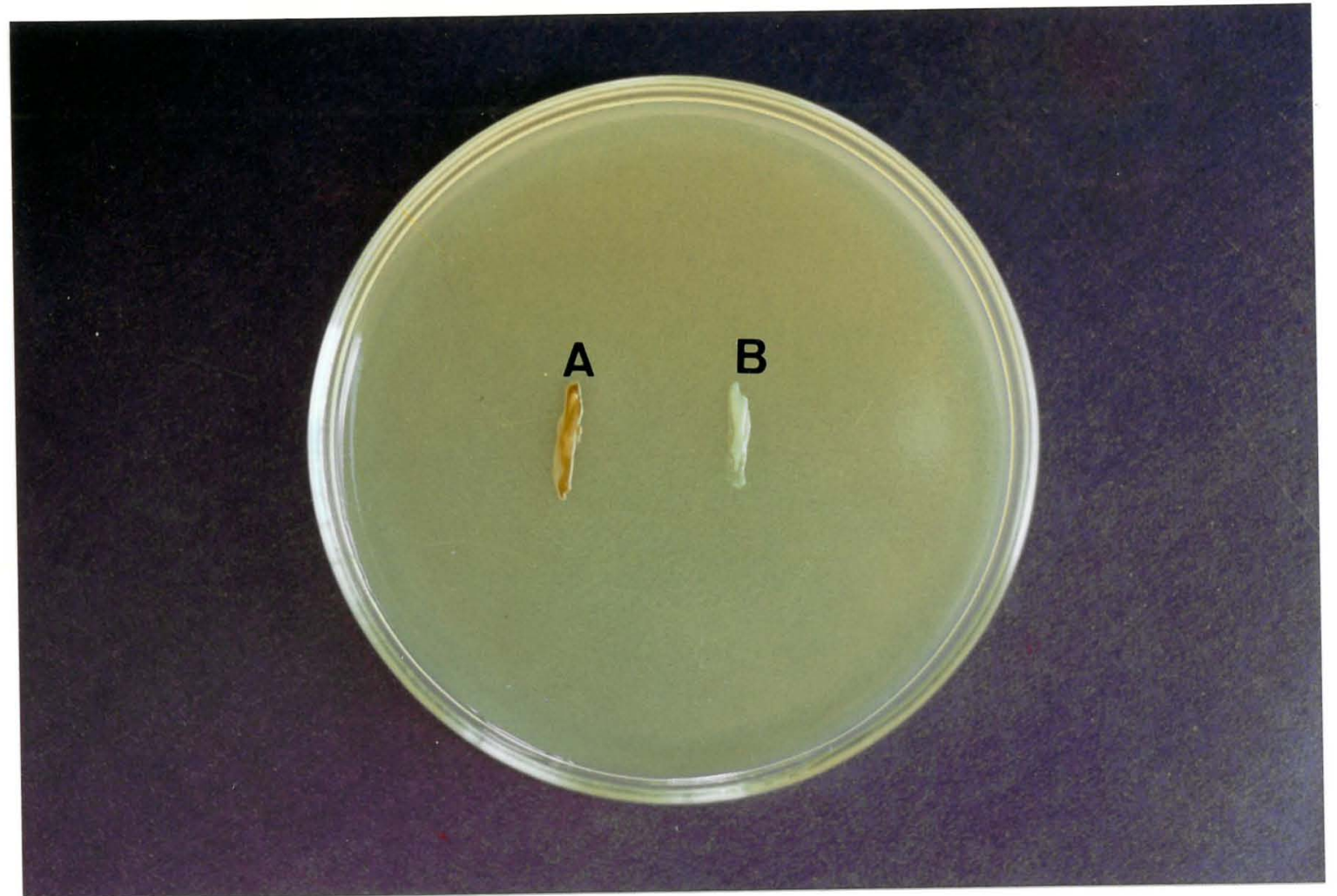

Figura 7 - Leveduras em meio BSA, após 24 horas de cultivo: (A) linhagem $\mathrm{H}_{2} \mathrm{~S}^{+}$; (B) linhagem $\mathrm{H}_{2} \mathrm{~S}^{-}$.

\subsection{Teste de floculação}

Foi empregado um teste visual em culturas estáticas. As linhagens foram inoculadas em tubos de ensaio contendo aproximadamente $5 \mathrm{~mL}$ de meio YEPD (item 3.2.1) e foram incubadas a $28^{\circ} \mathrm{C}$ por 48 horas. Transcorrido o período de incubação, a cultura depositada no fundo do tubo foi homogeneizada com o meio de cultura em agitador tipo Vortex e a avaliação consistiu na visualização dos flocos suspensos no meio de cultura (Suzzi et al., 1984).

\subsection{Curva de sobrevivência à luz ultravioleta}

Foi feita uma suspensão celular em solução salina (item 3.3.1) e estimado o número de células por mililitro ao microscópio ótico, com o auxílio de uma câmara de Neubauer. A concentração foi ajustada para aproximadamente $10^{6}$ células por $\mathrm{mL}$. Dez mililitros desta suspensão foram colocados em placa de Petri estéril a $14 \mathrm{~cm}$ de 
distância de uma fonte de luz ultravioleta de ondas curtas (Mineralight lamp Model UVSL-25, 115 volts, 0,16 AMPS, Ultra-Violet Prod. Inc., San Gabriel, Califórnia, EUA).

Antes do início da irradiação, a lâmpada permaneceu ligada por 20 minutos e o experimento foi realizado na ausência de luz branca. Antes de expor a suspensão celular em placa de Petri à luz UV, foi retirada uma alíquota de 1,0 $\mathrm{mL}$ da mesma, para servir de controle. As células foram expostas durante 10, 20, 30, 40, 50, 60 e 70 segundos à luz UV. Após cada período de irradiação, uma alíquota de $1,0 \mathrm{~mL}$ foi retirada. Assim como o controle, foram diluídas em solução salina e $0,1 \mathrm{~mL}$ de cada diluição foi inoculado em meio YEPD (3 repetições). Estas placas foram incubadas a $28^{\circ} \mathrm{C}$ por aproximadamente 48 horas. Após este período, foi procedida a contagem das colônias, que representaram as unidades formadoras de colônias (UFC), e foi elaborada a curva de sobrevivência.

A porcentagem de sobrevivência foi estimada em relação ao número de colônias obtidas no tratamento controle, tomado como $100 \%$ de sobrevivência. Estimouse, deste modo, o tempo de irradiação necessário para inviabilizar $95 \%$ das células em suspensão. A porcentagem de sobrevivência foi calculada pela fórmula:

$$
\text { Sobrevivência }(\%)=\frac{\text { número de colônias desenvolvidas (UFC) }}{\text { número de UFC do controle }} \times 100
$$

\subsection{Obtenção de mutantes auxotróficos}

Uma suspensão de células contendo cerca de $10^{6}$ células por mililitro de solução salina, foi submetida ao tratamento mutagênico com a luz UV, pelo tempo que permita $5 \%$ de sobrevivência. Após o tratamento mutagênico, $0,1 \mathrm{~mL}$ de diluições apropriadas foram semeadas em meio YEPD. As placas foram incubadas por aproximadamente 48 horas a $28^{\circ} \mathrm{C}$, quando foi procedida a transferência das colônias obtidas, com auxilio de palitos esterilizados, para duas séries de placas de 26 pontos (uma contendo meio mínimo e outra com meio YEPD), técnica da réplica de Lederberg \& 
Lederberg (1952). Estas placas foram incubadas por 72 horas. As colônias que não apresentaram crescimento em meio mínimo foram consideradas mutantes e, após recuperação do YEPD, foram caracterizadas quanto a auxotrofia.

\subsection{Caracterização dos mutantes auxotróficos}

Os mutantes auxotróficos foram caracterizados segundo a técnica de auxonografia (Pontecorvo et al, 1953). Esta técnica consiste em preparar placas contendo meio mínimo (MM - item 3.2.2) e semeá-las com 0,1 mL de uma suspensão de células mutantes. Posteriormente, $10 \mu \mathrm{L}$ das soluções de vitaminas (item 3.3.2), de ácidos nucléicos (item 3.3.3) e de caseína hidrolisada (item 3.3.4), são dispostos em locais diferentes nas placas. $\mathrm{O}$ crescimento visível, ao redor de qualquer uma dessas soluções, indica a deficiência da linhagem mutante. Para a caracterização final das células mutantes, foi utilizado o método proposto por Holliday ${ }^{15}$ e Takahashi ${ }^{16}$, citados por Azevedo (1972), que consiste na utilização de 5 meios de cultura, cada um com a combinação de 5 suplementos nutricionais. Assim, com 5 placas pode-se testar 15 requerimentos (item 3.3.5) nutricionais diferentes, como demonstrado no Tabela 3.

\subsection{Teste de reversão}

Para se avaliar a freqüência de reversão das marcas auxotróficas, foram feitas suspensões celulares dos mutantes obtidos, de aproximadamente $10^{6}$ células por $\mathrm{mL}$ de salina. A seguir, foram semeados $0,1 \mathrm{~mL}$ dessas suspensões em meio mínimo (item 3.2.3) e diluições apropriadas foram semeados em YEPD. As placas foram incubadas por 5 a 7 dias a $28^{\circ} \mathrm{C}$, quando procedeu-se à contagem das colônias. A frequiência de reversão foi calculada pela seguinte relação: $\mathrm{n}^{\circ}$ médio de UFC em meio mínimo/ $\mathrm{n}^{\circ}$ médio de UFC em YEPD.

${ }^{15}$ HOLIDAY, R. Nature, London, v.178, p.987, 1956.

16 TAKAHASHI, T. Report Kihara Inst. Biol. Res., v.10, n.57, 1959. 
Tabela 3 - Esquema da organização dos meios-de cultura para caracterização de mutantes auxotróficos.

\begin{tabular}{cccc}
\hline $\begin{array}{c}\text { Meio de Cultura } \\
\text { número }\end{array}$ & $\begin{array}{c}\text { Suplementos adicionados } \\
\text { S }\end{array}$ & Se o auxotrófico crescer em & $\begin{array}{c}\text { Substância } \\
\text { requerida }\end{array}$ \\
2 & F B G H I E & 1 & A \\
3 & J C G K L & 2 & F \\
4 & M D H K N & 3 & J \\
5 & OE I L N & 4 & M \\
& & 5 & O \\
& & 1 e 2 & B \\
& & 1 e 3 & C \\
& & 1 e 4 & D \\
& & 1 e 5 & E \\
& 2 e 3 & G \\
& 2 e 4 & H \\
& 2 e 5 & I \\
& 3 e 4 & K \\
& 3 e 5 & L \\
\hline
\end{tabular}

Fonte: Holliday; Takahashi, citados por Azevedo (1972)

\subsection{Curva de crescimento em meio YEPD}

A curva de crescimento em meio YEPD, foi feita pela estimativa do número de células totais ao microscópio ótico, com o auxilio de uma câmara de Neubauer. Foi feita uma suspensão de células provenientes de uma cultura de YEPD sólido, com 48 horas de crescimento, em solução salina, com a concentração celular de $5 \times 10^{5}$ a $1 \times 10^{6}$. Um mililitro desta suspensão foi transferido para erlenmeyer de $250 \mathrm{~mL}$ contendo $50 \mathrm{~mL}$ de YEPD líquido, sendo a concentração inicial em torno de 1 a $5 \times 10^{4}$ 
células por $\mathrm{mL}$ de meio. Estes frascos, por suavez, foram incubados a $28^{\circ} \mathrm{C} \mathrm{em}$ agitador a $150 \mathrm{rpm}$. Alíquotas foram retiradas a cada intervalo de 3 horas, durante 39 horas ou até obter-se um platô de crescimento, sendo imediatamente observadas e estimadas suas concentrações em câmara de Neubauer. Quando necessário diluições, estas foram feitas em solução salina a partir de amostra de $0,1 \mathrm{~mL}$.

\subsection{Obtenção de protoplastos}

Foi feito um experimento a fim de determinar o tempo necessário para a obter aproximadamente $100 \%$ de protoplastização. Um mililitro de uma suspensão celular contendo entre $5 \times 10^{5}$ a $1 \times 10^{6}$ células por $\mathrm{mL}$ foi transferido para frascos contendo 50 $\mathrm{mL}$ de YEPD líquido. Estes frascos foram agitados a $150 \mathrm{rpm}$ durante o tempo necessário para que a cultura atingisse a metade da fase exponencial de crescimento, com a concentração em torno de $10^{7}$ a $10^{8}$ células por $\mathrm{mL}$. Após este período, as células foram coletadas por centrifugação a aproximadamente $3000 \mathrm{~g}$ e lavadas duas vezes com EDTA $10 \mathrm{mM}$ (item 3.3.6); após cada lavagem as células foram ressuspensas. Após a segunda lavagem o precipitado foi ressuspendido em $5 \mathrm{~mL}$ de EDTA $10 \mathrm{mM}$. A esta suspensão foi adicionado $50 \mu \mathrm{L}$ de 2-mercaptoetanol e incubada por 10 minutos a $28^{\circ} \mathrm{C}$. A seguir esta suspensão foi lavada duas vezes com TSP $1 \mathrm{M}$ (3.3.5), e o precipitado da segunda lavagem foi ressuspenso em 2 a $5 \mathrm{~mL}$ de TSP $1 \mathrm{M}$, a fim de obter-se uma concentração em torno de $10^{8}$ células por $\mathrm{mL}$. Foi retirada uma alíquota de $0,1 \mathrm{~mL}$, para servir de controle.

A suspensão restante foi dividida em dois erlenmeyers de no máximo 50 $\mathrm{mL}$, em quantidades idênticas. Num foi adicionada a enzima lítica (item 3.3.7) (frasco A), numa proporção de $0,1 \mathrm{~mL}$ de solução lítica para cada $\mathrm{mL}$ de suspensão celular e o outro permaneceu sem enzima, servindo como testemunha (frasco B). Estes erlenmeyers foram incubados a $28^{\circ} \mathrm{C}$ com branda agitação. Amostras foram colhidas por centrifugação a $1000 \mathrm{~g}$, após 30 e 60 minutos de ação da enzima, e lavadas por três vezes em TSP. E, assim como o controle, $0,1 \mathrm{~mL}$ de diluições apropriadas, em TSP $1 \mathrm{M}$, foram semeadas em meio YEPD sólido. 
O grau de formação de protơplastos foi estimado como o proposto por Gunge \& Tamaru (1978), pela comparação do número de colônias produzidas pelo plaqueamento de células tratadas com a enzima lítica (frasco $\mathrm{A}$ ), sobre o meio YEPD, com o número de colônias obtidas pelo plaqueamento de igual concentração de células não tratadas por enzima lítica (frasco B).

\subsection{Regeneração de protoplastos}

Para determinar a porcentagem de regeneração, foram utilizadas as diluições das amostras colhidas no item 3.9, que foram tratadas com a enzima lítica (frasco A). Alíquotas de um mililitro de diluições apropriadas foram semeadas pela técnica pour plate em meio de YEPD de regeneração de protoplastos 1,2 M (item 3.2.4), bem como alíquotas de $0,1 \mathrm{~mL}$, de diluições apropriadas foram plaqueados por superfície, em YEPD sem estabilizador osmótico.

O grau de regeneração de protoplastos foi estimado pela comparação do número de colônias crescidas em meio YEPD com e sem estabilizador osmótico. $\mathrm{O}$ excesso de colônias desenvolvidas em YEPD com estabilizador foi considerado como devido à regeneração de protoplastos (Gunge \& Tamaru, 1978).

\subsection{Fusão de protoplastos}

Foram obtidos protoplastos derivados de duas linhagens com auxotrofias contrastantes, segundo a metodologia descrita no item 3.8. Às suspensões de protoplastos em TSP, foram adicionados alíquotas de solução de $\mathrm{CaCl}_{2}$ 1,2 $\mathrm{M}$ (item 3.3.8) numa proporção de $1: 4(250 \mu \mathrm{L} / \mathrm{mL}$ de suspensão). Posteriormente, essas suspensões contendo protoplastos foram misturados em igual quantidade e centrifugados por 10 minutos a 1000 g. O sobrenadante foi removido e $1 \mathrm{~mL}$ da solução de PEG $40 \%$ (item 3.3.9) foi adicionado e misturado com auxilio de um bastão de vidro. Após incubação a $30^{\circ} \mathrm{C}$ por 30 minutos, a mistura foi centrifugada e lavada por três vezes em TSP e diluições apropriadas foram semeadas pela técnica pour plate em meio mínimo para regeneração dos produtos de fusão (MM-sorbitol 1,2 M - item 3.2.5), meio YEPD- 
sorbitol e meio YEPD. As placas foram ineuubadas por $7-10$ dias a $28^{\circ} \mathrm{C}$, quando procedeu-se à contagem das colônias presentes nos dois meios.

A freqüência de fusão citoplasmática foi estimada pela seguinte relação: número médio de colônias presentes em MM-sorbitol/ número médio de colônias desenvolvidas em meio YEPD-sorbitol menos o número médio de colônias desenvolvidas em meio YEPD.

As colônias que crescerem no meio seletivo para fusão foram transferidas para placas de 26 pontos com MM sem estabilizador osmótico para confirmar a fusão nuclear. As colônias que persistiram o crescimento, nessas placas, foram consideradas hibridas.

\subsection{Teste de estabilidade dos produtos de fusão}

Algumas colônias consideradas hibridas foram avaliadas quanto a sua estabilidade. Após crescimento em meio mínimo, foram transferidas para meio YEPD sólido e incubadas por 48 horas. A seguir, cada colônia foi inoculada em $100 \mathrm{~mL}$ de YEPD líquido em frascos erlenmeyer e colocadas para incubar em agitador a $150 \mathrm{rpm}$, a $28^{\circ} \mathrm{C}$ por 24 horas. Destas culturas, um mililitro, foi transferido para outro erlenmeyer contendo YEPD e incubado nas mesmas condições por mais 24 horas. $O$ último procedimento foi repetido mais uma vez, perfazendo o total de três subcultivos. No terceiro subcultivo foi retirada uma alíquota de $0,1 \mathrm{~mL}$, efetuadas as devidas diluições e procedida a inoculação das culturas obtidas a partir dos produtos de fusão avaliados, sendo as foram incubadas em BOD a $28^{\circ} \mathrm{C}$. As colônias que cresceram isoladas foram testadas quanto a produção de $\mathrm{H}_{2} \mathrm{~S}$ (item 3.4) e floculação (item 3.5). Após 3 subcultivos, os produtos de fusão que apresentassem $100 \%$ de colônias $\mathrm{H}_{2} \mathrm{~S}^{-}$e floculantes eram considerados estáveis. 


\subsection{Técnicas moleculares}

\subsubsection{Eletroforese de campo pulsado - Pulsed-Field - para separação de DNA cromossômico de leveduras}

As linhagens foram incubadas em erlenmeyers contendo $100 \mathrm{~mL}$ de meio YEPD, a $28^{\circ} \mathrm{C}$ e sob agitação constante $(150 \mathrm{rpm})$, até a metade da fase exponencial de crescimento. Foram colhidas por centrifugação (10 minutos a $5000 \mathrm{~g})$ e lavadas três vezes com EDTA 0,05 M, pH 8,0 (item 3.3.16). Após as lavagens, as células foram ressuspendidas na solução de EDTA até uma concentração final de aproximadamente $5 \times 10^{9}$ células $/ \mathrm{mL}$ (Bellis et al, 1987). Esta suspensão de células foi aquecida a $42^{\circ} \mathrm{C}$ e a seguir foi misturada com agarose LGT (low gelling temperature) $1,4 \%$ (item 3.3.11), na proporção de $1: 1$ e imediatamente foram transferidas para moldes de plugs. O molde contendo as amostras foi colocado no refrigerador para solidificação dos plugs. Após a solidificação do gel, com auxílio de espátula, os plugs foram transferidos para tubos contendo tampão NDS (item 3.3.12) com proteinase K (1 mg de proteinase $\mathrm{K} / \mathrm{mL}$ de tampão) e incubados em banho-maria à $50^{\circ} \mathrm{C}$ por aproximadamente 15 horas (Ibeas \& Jimenez, 1993).

Decorrido o tempo de incubação, os plugs foram lavados quatro vezes, sendo as três primeiras com EDTA $0,05 \mathrm{M}$ pH 8,0 e última com o tampão de corrida TBE 0,5X (item 3.3.15). Após a última lavagem, os plugs foram estocados a $4^{\circ} \mathrm{C}$ no próprio tampão de corrida TBE 0,5 X. Os plugs contendo amostras de DNA íntegro das leveduras, foram inseridos nas canaletas do gel de agarose 1\% (item 3.3.13) e selados com a mesma agarose. O gel foi transferido para câmara do equipamento CHEF-DR II (Bio Rad), contendo tampão TBE $0,5 \mathrm{X}$, previamente resfriado a $14^{\circ} \mathrm{C}$ (McCluskey et al., 1990).

A corrida para a separação do DNA cromossômico foi realizada em 23 horas, a 200 volts e $14^{\circ} \mathrm{C}$, sendo as primeiras 15 horas com pulsos de 60 segundos e as 8 horas restantes com pulsos de 90 segundos (Naumov et al., 1992). Após o término da corrida o gel foi removido da câmara e corado com brometo de etídio (10 $\mu \mathrm{l} / \mathrm{mL}$ - item 
3.3.16) por aproximadamente $30 \mathrm{~min} \mathrm{e}$ - observado sob luz ultravioleta em transiluminador. O gel corado foi descorado em água, e então fotografado (Filme Polaroid 667 ou Fuji FP 699), sob transiluminador de UV e filtro laranja.

\subsubsection{Estimativa do peso molecular das bandas cromossômicas}

Os valores de peso molecular $(\mathrm{Mb})$, das linhagens estudas e obtidas, foram estimados pelo diagrama traçado empregando-se o log do peso molecular do padrão Saccharomyces cerevisiae versus a distância de migração no gel $(\mathrm{cm})($ Gilly \& Sands, 1991).

\subsubsection{Polimorfismo de DNA amplificado ao acaso - RAPD (Random Amplified Polimorphic DNA)}

As amplificações foram feitas num volume total de $25 \mu \mathrm{L}$ contendo 20 $\mathrm{mM}$ de Tris-HCl, $\mathrm{pH} 8,4,50 \mathrm{mM}$ de $\mathrm{KCl}, 3,75 \mathrm{mM}$ de $\mathrm{MgCl}_{2}, 100 \mu \mathrm{M}$ de cada desoxinucleotideo (d NTP's), $30 \mathrm{ng}$ de oligonucleotídios iniciadores (primer), $40 \mathrm{ng}$ de DNA e 1,5 U de Taq DNA Polimerase (Gomes et al., 1995). Os primers utilizados, bem como suas seqüências nucleotídicas e seus pesos moleculares encontram-se na Tabela 4 .

Tabela 4. - Seqüência de nucleotídios e pesos moleculares dos primers utilizados.

\begin{tabular}{ccc}
\hline Primers & Sequência & Peso Molecular \\
\hline OPB-10 & CTGCTGGGAC & 3035 \\
OPB-12 & CCTTGACGCA & 2979 \\
OPB-17 & AGGGAACGAG & 3117 \\
OPX-10 & CCCTAGACTG & 2979 \\
OPX-16 & CTCTGTTCGG & 3001 \\
\hline
\end{tabular}


A pré-desnaturação foi feita $92^{\circ} \mathrm{C}$ por 2 minutos seguida de 40 ciclos de 1 minuto a $92^{\circ} \mathrm{C}, 1$ minuto a $37^{\circ} \mathrm{C}$ e 2 minutos a $72^{\circ} \mathrm{C}$, com uma extensão final de 3 minutos a $72^{\circ} \mathrm{C}$ em termo ciclador PTC- $100^{\mathrm{TM}}$ da M J RESEARCH INC.

Os produtos amplificados foram separados por eletroforese, em gel de agarose $1,3 \%$ (item 3.3 .23 ), à $2,9 \mathrm{~V} / \mathrm{cm}$, por aproximadamente 3 horas e 30 minutos. Foi utilizado DNA de lambda clivado com enzima de restrição Hind III como marcador de peso molecular. O gel foi corado com solução de brometo de etídio por $30 \mathrm{~min}$ e descorado em água para posterior observação e fotografia em transiluminador de luz ultravioleta, com filme Polaroid 667 ou Fuji FP 699, com filtro laranja.

\subsubsection{Isolamento de DNA de levedura para RAPD}

As linhagens foram crescidas em $100 \mathrm{~mL}$ de meio YEPD até a metade de fase logarítmica de crescimento, a $28^{\circ} \mathrm{C}$ e sob agitação constante $(150 \mathrm{rpm})$. As células foram colhidas por centrifugação a $7000 \mathrm{~g}$ por 10 minutos. $\mathrm{O}$ sobrenadante foi descartado e a massa úmida foi transferida, com auxilio de pipeta, para almofariz previamente congelado com nitrogênio líquido. A massa celular foi congelada com nitrogênio líquido e com auxilio de um pistilo foi macerada até obter-se um pó branco.

A massa celular macerada foi ressuspendida em $3 \mathrm{~mL}$ de Tris- $\mathrm{HCl} 0,1$ $\mathrm{M} \mathrm{pH} \mathrm{8,0.} \mathrm{Parte} \mathrm{da} \mathrm{suspensão} \mathrm{celular} \mathrm{foi} \mathrm{transferida} \mathrm{para} \mathrm{tubos} \mathrm{de} \mathrm{microcentrífuga} \mathrm{de} \mathrm{1,5}$ $\mathrm{mL}$, sendo $650 \mu \mathrm{L}$ de suspensão por tubo. Foi adicionado a cada tubo $65 \mu \mathrm{L}$ de 2mercaptoetanol, misturado por inversão e logo em seguida foi acrescentado $75 \mu \mathrm{L}$ da solução de SDS $10 \%$ (item 3.3.17) e novamente misturado por inversão por aproximadamente 5 minutos ou até a obtenção de uma solução viscosa.

Após o rompimento das células e a lise das estruturas membranosas, foi procedido o processo de desproteinização. À solução viscosa foi adicionado 1 volume da solução de clorofane (item 3.3.18) e misturado delicadamente, por inversão, até a homogeneização e centrifugado a $12000 \mathrm{~g}$ por 10 minutos. $\mathrm{O}$ sobrenadante foi transferido para outro tubo de microcentrífuga, com auxilio de micropipeta, evitando-se os depósitos de proteínas na interfase da mistura. A desproteinização foi repetida por três 
vezes, sendo as duas primeiras com solução de clorofane e a terceira com solução de clorofil (item 3.3.19).

A fim de efetuar-se a precipitação dos ácidos nucleicos foi adicionado ao conteúdo da última desproteinização $5 \%$ do seu volume de Acetato de Sódio $3 \mathrm{M}, \mathrm{pH}$ 4,8 (item 3.3.20). A mistura foi lentamente homogeneizada e a seguir foram adicionados 2 volumes de etanol absoluto gelado a $-20^{\circ} \mathrm{C}$, a solução foi lentamente misturada enquanto ocorria a precipitação dos ácidos nucleicos e deixada a $-20^{\circ} \mathrm{C}$ por alguns minutos. Centrifugou-se por alguns segundos antes de descartar o etanol.

Após a precipitação dos ácidos nucleicos o sobrenadante foi descartado por inversão, tomando-se o cuidado para não descartar junto as fibras de ácidos nucleicos. O precipitado foi lavado com etanol 70\% (sem ressuspensão), o mesmo foi descartado e os tubos foram deixados invertidos para a total evaporação do etanol. Os ácidos nucleicos foram ressuspendidos em $1 \mathrm{~mL}$ de tampão TE (item 3.3.21) (Johnston et al., 1988).

\subsubsection{Quantificação e análise da integridade do DNA}

A integridade do DNA foi verificada por meio de eletroforese do DNA em gel de agarose $0,8 \%$, com tampão TBE $1 \mathrm{X}$, numa corrida de 1 hora e 30 minutos a 50 volts. Após a eletroforese o gel foi corado com brometo de etídio e observado em transiluminador de luz ultravioleta.

As amostras de DNA obtidas foram quantificadas por espectrofotometria em aparelho BECKMAN DU 640 ( $\lambda$ 260) ou Gene Quant.

\subsubsection{Construção de dendrogramas}

Os dados obtidos por amplificação ao acaso do DNA genômico (RAPD) foram transformados em variáveis binárias, ou seja, o número 1 significou presença de bandas e o número 0 a ausência de bandas, e desta forma foram introduzidos no programa NTSYS-PC (Applied Biostatistics, Inc). Este programa produziu uma matriz de similaridade com os dados introduzidos, utilizando o coeficiente de similaridade 
SM e para a elaboração dos dendrogramas, as matrizes foram analisadas pelo método de agrupamento $S A H N$-Clustering (performance seqüencial de aglomeração hierárquica de grupos) com o método UPGMA ( método de agrupamento pareado sem peso com significado aritmético). Este dendrograma agrupou as linhagens, mostrando o nível de similaridade genética entre elas. 


\section{RESULTADOS E DISCUSSÃO}

\subsection{Obtenção de mutantes auxotróficos}

Uma série de experimentos foi realizadaa a fim de se obter os mutantes auxotróficos complementares necessários para a fusão de protoplastos. Para tanto, iniciou-se pela elaboração da curva de sobrevivência ao mutagênico luz ultravioleta (UV). A curva de sobrevivência à luz ultravioleta foi determinada, visando determinar a dose de irradiação necessária para a obtenção de $5 \%$ de sobrevivência da população. Esta é a dose mais comumente utilizada para a obtenção de mutantes auxotróficos de várias espécies de microrganismos, pois segundo Burnett (1975), um rendimento efetivo de mutantes só é obtido quando a taxa de sobreviventes após tratamento mutagênico for muito baixa, algo em torno de 1 a $5 \%$. Após vários ensaios e com as estimativas das porcentagens relativas de células sobreviventes, em cada intervalo de tempo, elaborou-se a curva de sobrevivência apresentada na Figura 8. O tempo de tratamento que se fez necessário para obter $5 \%$ de sobrevivência, correspondeu a 65 segundos, aproximadamente. Portanto este foi o tempo de irradiação utilizado para a obtenção de mutantes auxotróficos.

Após o tratamento, as colônias foram transferidas por réplica para meio mínimo e meio YEPD e após o período de incubação em ambos os meios, fez-se a seleção e posterior caracterização das linhagens que não se desenvolveram em meio mínimo. As colônias mutantes oriundas da linhagem IZ 987 foram investigadas quanto a deficiência nutricional pela técnica da auxonografia até mesmo para a caracterização final, pois a seleção inicial da deficiência apontou para o grupo das vitaminas e como a quantidade de requisitos nutricionais a serem testados neste grupo é pequeno, a técnica da auxonografia é indicada. Mas para os mutantes auxotróficos oriundos da linhagem 
ABXR.11B que indicaram uma deficiência para aminoácidos a caracterização final foi realizada pelo método proposto por Holliday e Takahashi, citados por Azevedo (1972), pois se trata de um grupo de requisitos nutricionais maior. Os resultados das freqüências de obtenção de mutantes auxotróficos estão apresentados na Tabela 5. Como pode ser observado na referida tabela, a linhagem IZ 987 obteve um único tipo de auxotrofia, bem como uma proporção de mutantes cinco vezes superior ao da linhagem ABXR.11B.

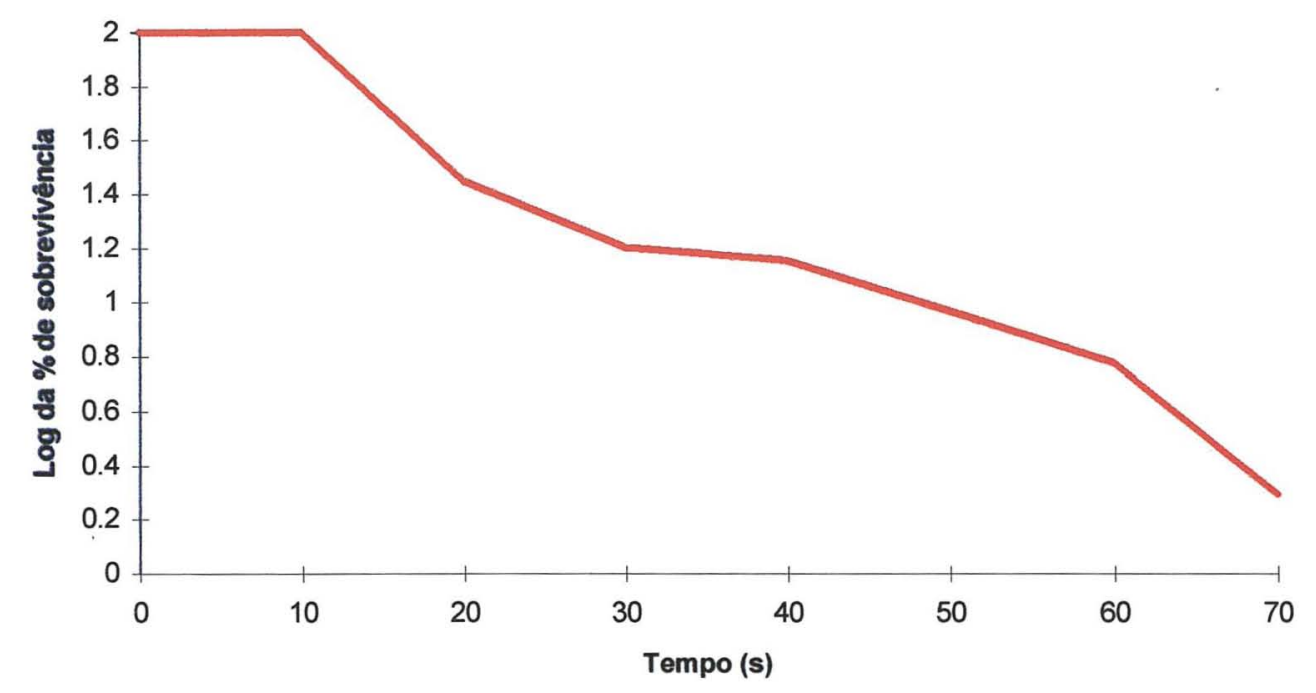

Figura 8 - Curva de sobrevivência da linhagem ABXR.11B de Saccharomyces cerevisiae à luz ultravioleta.

$\mathrm{Na}$ tentativa de explicar o grande número de mutantes auxotróficos para piridoxina na linhagem IZ 987, recorreu-se às observações de Fincham et al. (1979), os quais verificaram que o rendimento de um determinado mutante é variável com a espécie, e que em cada caso existe um requisito nutricional obtido mais freqüentemente. Uma vez que esta linhagem mostrou-se bioquimicamente diferente da espécie 
Saccharomyces cerevisiae, pode-se especular que a incidência de uma auxotrofia única seja dada por características típicas deste microrganismo.

Tabela 5 - Freqüência de obtenção de mutantes auxotróficos das linhagens IZ 987 e ABXR.11B após tratamento com UV e respectiva nomenclatura.

\begin{tabular}{|c|c|c|c|c|}
\hline Linhagem & $\begin{array}{c}\mathrm{n}^{0} \text { de colônias } \\
\text { analisadas }\end{array}$ & $\begin{array}{l}\% \text { de mutantes } \\
\text { auxotróficos }\end{array}$ & $\begin{array}{c}\text { mutantes } \\
\text { auxotróficos }\end{array}$ & nomenclatura \\
\hline IZ 987 & 624 & 1,28 & 8 piridoxina & $\begin{array}{l}p d x^{-1} \\
p d x^{-2} \\
p d x^{-3} \\
p d x^{-4} \\
p d x^{-5} \\
p d x^{-6} \\
p d x^{-} 7 \\
p d x-8\end{array}$ \\
\hline ARXR.11B & 806 & 0,248 & $\begin{array}{l}1 \text { arginina } \\
1 \text { metionina }\end{array}$ & $\begin{array}{l}\text { arg } \\
\text { met }\end{array}$ \\
\hline
\end{tabular}

Do mesmo modo, Whelan \& Magee (1981) observaram em algumas linhagens de Candida albicans, que houve uma taxa de obtenção de mutantes auxotróficos de 0,2 a $1,7 \%$ após tratamento com UV, sendo todos deficientes para o mesmo requerimento nutricional. Os autores constataram que isto ocorreu devido a 
ploidia das linhagens, pois elas eram diplóides e heterozigotas para alguns genes recessivos auxotróficos, que sob a ação da luz UV, segregam e dão origem a linhagens prototróficas e auxotróficas.

Para melhor esclarecer este resultado, as linhagens originais (IZ 987 e ABXR.11B) foram investigadas quanto a esporulação. Foram semeadas em meio rafinose acetato (item 3.2.6), que é um meio indutor da esporulação, no qual espera-se que linhagens diplóides de leveduras, esporulem. Constatou-se que ambas as linhagens foram incapazes de esporular, levando a conclusão de que ou são haplóides ou que sejam diplóides que apresentam alguma dificuldade em esporular.

Como não foi possível determinar com certeza o nível de ploidia da linhagem IZ 987, pode-se basear na hipótese de Whelan \& Magee (1981) para tentar explicar a obtenção de somente um tipo de mutante na referida linhagem. A linhagem IZ 987 seria heterozigota para $p d x^{+} / p d x^{-}$e sob a ação da luz UV, que é um agente indutor de permutas mitóticas, os alelos mutante e selvagem segregariam, originando colônias auxotróficas e prototróficas.

Quanto à taxa de mutação superior da linhagem IZ 987 pode-se levantar os seguintes pontos: (a) foi utilizado o tempo de exposição à luz ultravioleta que permite 5\% de sobrevivência determinado para a linhagem $\mathrm{ABXR}$.11B; (b) não foi feito um controle no momento da exposição, para verificar quanto de sobrevivência esta incidência do mutagênico proporcionaria. Estas observações indicam que a exposição da linhagem IZ 987 ao agente mutagênico por 65 segundos apresenta uma taxa de sobrevivência menor, permitindo assim um aumento na taxa de mutação.

\subsection{Teste de reversão}

As deficiências dos mutantes auxotróficos obtidos, foram avaliadas quanto à freqüência de reversão espontânea para o estado selvagem. Nenhum revertente foi observado, em $10^{6}$ células em 5 repetições, para todas as mutações auxotróficas 
avaliadas (piridoxina, metionina e arginina), conforme ilustra a Tabela 6. Os resultados demonstram estabilidade genética nos mutantes obtidos, permitindo a utilização destes em técnicas genéticas como a fusão de protoplastos.

Tabela 6 - Reversão espontânea dos mutantes auxotróficos das linhagens ABXR.11B e IZ 987.

Reversão

ABXR.11B arg

Ausente

ABXR.11B met

Ausente

IZ987 $p d x^{-} 1$

Ausente

IZ987 $p d x-2$

Ausente

IZ987 $p d x^{-3} 3$

Ausente

IZ987 $p d x^{-} 4$

Ausente

IZ987 $p d x=5$

Ausente

IZ987 $p d x^{-} 6$

Ausente

IZ987 $p d x^{-} 7$

Ausente

IZ987 $p d x^{-} 8$

Ausente 


\subsection{Curva de crescimento em YEPD}

Os protocolos que descrevem a obtenção de protoplastos em Saccharomyces cerevisiae, bem como em outros gêneros de leveduras ou até mesmo em fungos filamentosos, fazem uso das culturas na fase exponencial de crescimento (Svoboda, 1978); outro, mais especificamente, na metade desta fase (Russell \& Stewart, 1979) ou no final dela (Gunge \& Tamaru, 1978). Portanto, foi realizado um experimento a fim de determinar o tempo de incubação, de ambos os mutantes selecionados para a obtenção e fusão de protoplastos, em meio YEPD, necessário para que atinjam a metade da fase logarítmica de crescimento.

Inicialmente procedeu-se à elaboração da curva de sobrevivência com base na observação do crescimento por 39 horas, mas com este tempo não foi possível identificar com clareza a fase estacionária de crescimento da linhagem IZ 987. Assim, se fez necessário a observação do crescimento desta linhagem por mais 15 horas e mesmo assim, a curva de crescimento da linhagem IZ 987 não foi tão característica quanto a da linhagem ABXR.11B, por não apresentar bem definida as várias fase ou estágios do crescimento.

Os resultados obtidos estão apresentados em forma de curva de crescimento na Figura 9, com base na média de três repetições. Pode-se observar através da Figura 9 que para a linhagem ABXR.11B o tempo necessário para que a cultura atinja a metade da fase log de crescimento foi de 15 horas, enquanto que para a linhagem IZ 987 o tempo necessário foi de 21 horas. Assim esses tempos foram utilizados para a obtenção das células a serem protoplastizadas.

Pode-se observar mais uma vez a diferenciação entre as linhagens sendo esta fisiológica, de velocidade de crescimento. Mais uma vez a linhagem IZ 987 apresentou comportamento diferencial quanto ao esperado para leveduras da espécie Saccharomyces cerevisiae, uma vez que estas leveduras atingem a metade da fase logarítmica de crescimento em torno de 15 horas. 


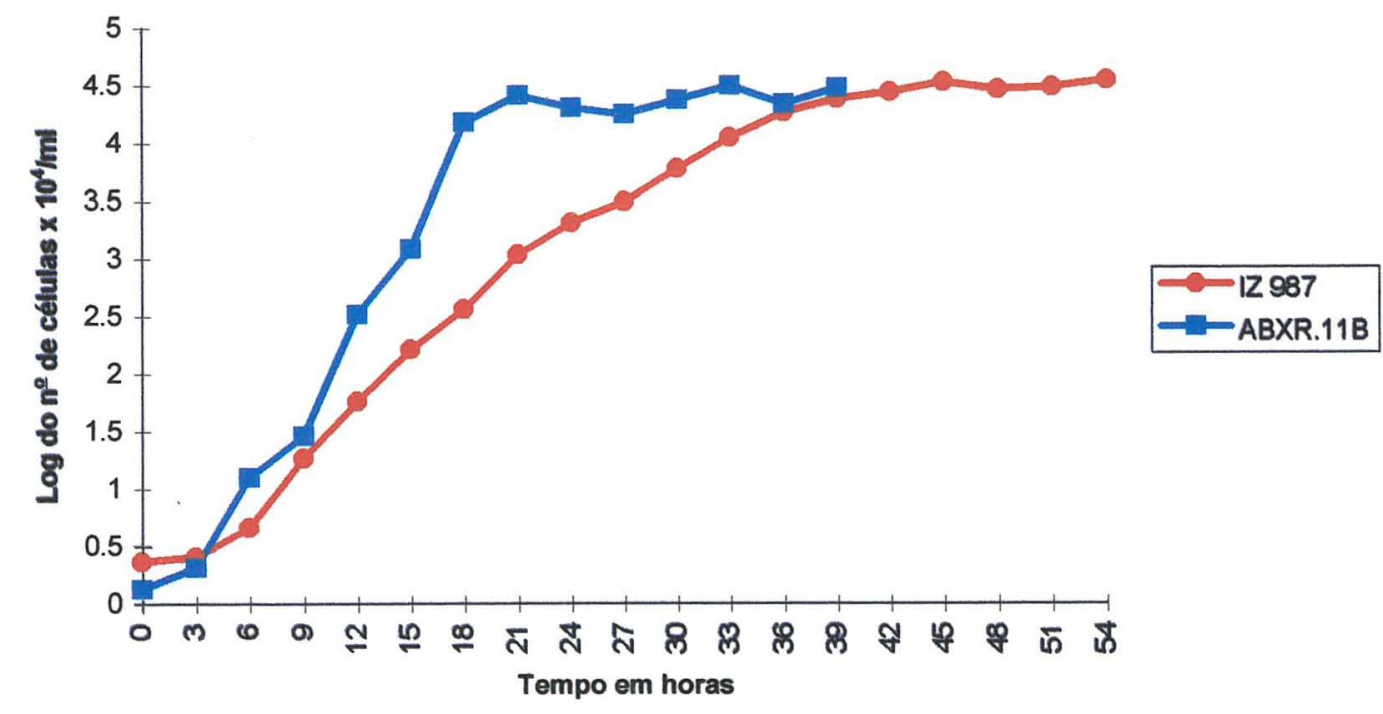

Figura 9 - Curva de crescimento em meio YEPD das linhagens ABXR.11B e IZ 987 (média de 3 repetições).

\subsection{Obtenção e regeneração de protoplastos}

Em experimentos variou-se o tempo de exposição das células à enzima protoplastizadora (item 3.3.7) para tentar otimizar um protocolo de obtenção e regeneração de protoplastos, conforme descrito no item 3.9 e 3.10. Os resultados obtidos quanto a obtenção e regeneração dos protoplastos de ambas as linhagens são apresentados na Tabela 7. 
Tabela 7 - Porcentagem da conversão das células em protoplastos e da regeneração dos protoplastos (média de duas repetições).

\begin{tabular}{lcccc}
\hline & \multicolumn{2}{c}{$\begin{array}{c}\% \text { de conversão de células } \\
\text { em protoplastos }\end{array}$} & \multicolumn{2}{c}{$\%$ de regeneração } \\
\hline Linhagem & $30 \mathrm{~min}$ & $60 \mathrm{~min}$ & $30 \mathrm{~min}$ & $60 \mathrm{~min}$ \\
\hline ABXR.11B & $99,97 \%$ & $99,96 \%$ & $1,385 \%$ & $1,368 \%$ \\
IZ 987 & $99,94 \%$ & $99,93 \%$ & $4,25 \%$ & $0,843 \%$ \\
\hline
\end{tabular}

A porcentagem de formação de protoplastos não aumentou com o tempo de exposição das células na enzima lítica, uma vez que no primeiro tempo de análise (30 minutos), já se verificou uma protoplastização de quase $100 \%$. Estes dados sugerem que a taxa de protoplastização já havia atingido um platô aos 30 minutos de exposição à enzima lítica. Hamlyn et al. (1981) obtiveram uma curva de produção de protoplastos em Penicillium chrysogenum, na qual a produção se mostrou constante no período entre 2 e 3 horas de exposição, isto após um período de aumento crescente na taxa de produção de protoplastos.

Quanto à relação tempo de exposição na enzima lítica versus porcentagem de regeneração, a linhagem IZ 987 apresentou comportamento esperado, pois o maior tempo de exposição à enzima leva a retirada total da parede celular e portanto mais dificil se torna a regeneração. Gunge \& Tamaru (1978), descreveram que quanto maior o tempo de exposição das células à enzima lítica menor o grau de regeneração.

Os protoplastos obtidos a partir de células da linhagem ABXR.11B após 60 minutos de exposição a enzima lítica são mostrados na Figura 10. 


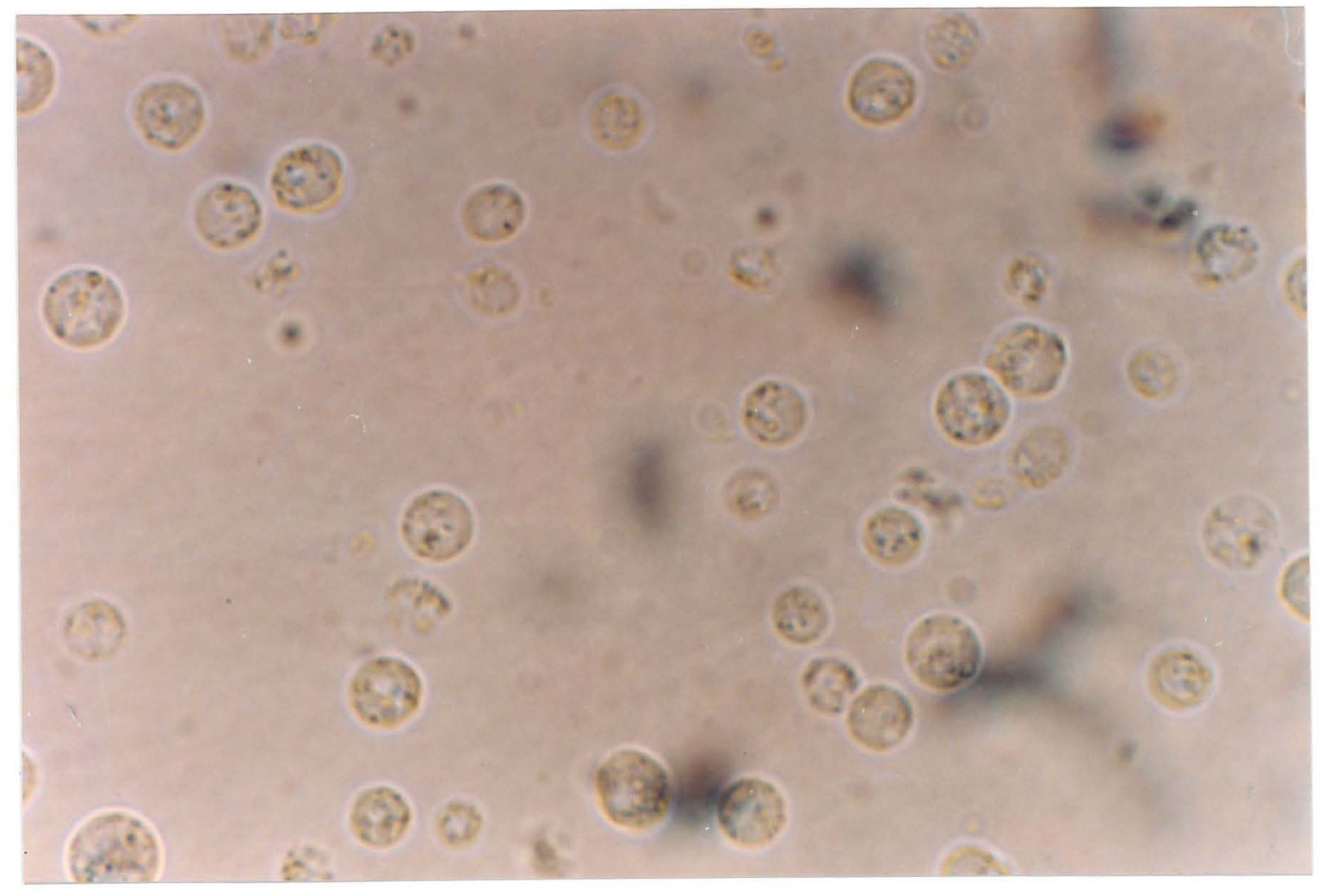

Figura 10 - Protoplastos obtidos a partir de células da linhagem ABXR.11B após 60 minutos de exposição à enzima Novozym 234. (Aumento 1000X - imersão)

\subsection{Fusão de protoplastos}

Uma vez determinado o tempo de exposição à enzima lítica que proporciona uma regeneração razoável (30 minutos), duas linhagens auxotróficas complementares, foram escolhidas para serem submetidas a fusão. A linhagem ABXR.11B apresentava deficiência para arginina ( $\left.\operatorname{~rrg~}^{-}\right)$, enquanto a linhagem IZ 987 
requeria piridoxina ( $\left.p d x^{-}\right)$e tiossulfato $\left(t i^{-}\right)$, sendo a última necessidade nutricional uma auxotrofia natural da linhagem.

A freqüência de fusão obtida $\left(\mathrm{n}^{\mathrm{o}}\right.$ de colônias em meio mínimo de regeneração/ $\mathrm{n}^{0}$ de colônias em YEPD de regeneração menos $o \mathrm{n}^{0}$ de colônias em YEPD) foi de $2,7 \times 10^{-4}$. Uma vez que as taxas de reversão das auxotrofias utilizadas foram nulas pode-se supor que as colônias desenvolvidas no meio mínimo de regeneração foram verdadeiros produtos de fusão citoplasmática. Esta taxa de fusão foi muito menor que a obtida por Farahnak et al (1986), entre linhagens auxotróficas de Saccharomyces cerevisiae e Kluyveromyces fragilis $\left(7 \times 10^{-1}\right)$. Trabalhando com Saccharomyces cerevisiae Gunge \& Tamaru (1978) obtiveram uma freqüência de colônias prototróficas de cerca de 1 para cada $10^{6}$ pares de protoplastos submetidos a fusão.

Os produtos de fusão citoplasmática foram transferidos para meio mínimo. Pode-se observar que $54,6 \%$ das colônias transferidas mantiveram a capacidade de crescimento neste meio de cultura. As colônias que não foram capazes de manter o seu crescimento no meio mínimo, provavelmente eram heterocários instáveis que dissociaram os núcleos parentais auxotróficos. Esta mesma situação foi verificada por Fungaro et al. (1992) quando analisavam produtos de fusão em Candida sp., onde observaram que cerca de $86 \%$ das colônias obtidas em meio mínimo de regeneração, segregavam as marcas parentais, sendo portanto heterocários instáveis, enquanto que Fournier et al (1977) encontraram 70\% de produtos de fusão estáveis em Candida tropicalis.

Entre os produtos de fusão com capacidade de crescimento em meio mínimo, de um deles (PF 70) foi feita uma suspensão celular e a mesma foi semeada em meio mínimo e YEPD. Após o crescimento das colônias procedeu-se à contagem e verificou-se que o número médio de colônias obtidas nos dois tipos de meio foi semelhante (207 e 227 em YEPD e meio mínimo, respectivamente). Este fato, sugere a estabilidade do produto de fusão em meio sólido e indica uma ocorrência de fusão nuclear. Este resultado vem de encontro aquele obtido por Fungaro et al. (1992), onde o híbrido obtido pela fusão de protoplastos Candida sp. apresentou crescimento semelhante 
em BDA (Batata Dextrose Agar) e meio mínimo, indicando produtos de fusão nuclear estáveis.

A fim de determinar a estabilidade dos produtos de fusão em meio líquido completo, uma vez que esta situação é similar ao que ocorrerá na dorna de fermentação, alguns produtos de fusão que mantiveram a prototrofia foram testados quanto a estabilidade. Nenhum dos produtos de fusão analisados manteve a estabilidade após três subcultivos em YEPD líquido, mas de 12 produtos de fusão testados, 3 apresentaram recombinantes com as características de floculação e não produção de $\mathrm{H}_{2} \mathrm{~S}$, conforme Tabela 8 .

Tabela 8 - Segregantes parentais e recombinantes dos produtos de fusão.

\begin{tabular}{l|c|c|c}
\hline Produto de Fusão & $\begin{array}{l}\text { Recombinantes } \\
\left(\mathrm{H}_{2} \mathrm{~S}^{-} \text {e Floculantes }\right)\end{array}$ & $\begin{array}{l}\text { Parentais }\left(\mathrm{H}_{2} \mathrm{~S}^{-} \text {e não }\right. \\
\text { Floculantes })\end{array}$ & $\begin{array}{l}\text { Parentais }\left(\mathrm{H}_{2} \mathrm{~S}^{+} \mathrm{e}\right. \\
\text { Floculantes })\end{array}$ \\
\hline PF 70 & 9 & 3 & 40 \\
\hline PF 67 & 11 & 68 & 24 \\
\hline PF 7 & 6 & 29 & - \\
\hline
\end{tabular}

Uma provável explicação para a alta instabilidade dos produtos de fusão em YEPD líquido é a grande diferença bioquímica e fisiológica, derivada de um grande distanciamento taxonômico existente entre as linhagens (como discutido no item 4.6). Carrau et al (1982) observaram que os produtos de fusão obtidos pelos cruzamentos entre Saccharomyces cerevisiae e Schizosaccharomyces pombe eram muito instáveis do ponto de vista genético e produziram diferentes tipos de segregantes. 
As linhagens recombinantes obtidas neste trabalho, que apresentaram as características de floculação e não produção de $\mathrm{H}_{2} \mathrm{~S}$, necessitam serem avaliadas quanto ao comportamento na parte tecnológica, para se saber da viabilidade do emprego industrial destas linhagens.

\subsection{Separação de DNA cromossômico em leveduras - Pulsed Field}

Com o propósito de verificar a relação taxonômica dos parentais submetidos à fusão de protoplastos, bem como analisar os produtos de fusão e os recombinantes obtidos, foi realizada a cariotipagem eletroforética destas leveduras.

Bandas individualizadas não representam necessariamente um cromossomo uma vez que os de igual peso molecular ou de peso molecular próximos, podem estar contidos em uma mesma banda. Dessa forma, empregou-se o termo banda cromossômica para designar as bandas visualizadas. Os padrões eletroforéticos das linhagens parentais ABXR.11B e IZ987, dos produtos de fusão 67 e 70 , e dos segregantes deles obtidos, $26 \mathrm{~S}, 15 \mathrm{~S}$ e $18 \mathrm{~S}$, estão apresentados na Figura 11, enquanto que na Figura 12 apresenta-se a representação esquemática do padrão eletroforético de cada linhagem.

Os valores de pesos moleculares das linhagens parentais ABXR.11B e IZ 987, dos produtos de fusão e do segregante 15 obtidos a partir dos pesos moleculares do padrão utilizado (Saccharomyces cerevisiae) estão representados na Tabela 9.

Observa-se que os padrões eletroforéticos dos parentais são muito diferentes, a linhagem IZ 987 mostrou a resolução de somente 6 bandas cromossômicas com uma variação de 2,3 a $1,125 \mathrm{Mb}$, enquanto que a linhagem ABXR.11B apresentou 14 bandas cromossômicas variando entre 2,09 a 0,215 Mb. O parental IZ 987 apresenta duas bandas cromossômicas de peso molecular igual ao parental ABXR.11B $(2,09$ e $1,125 \mathrm{Mb}$ ), sendo a banda de $1,125 \mathrm{Mb}$ comum também ao padrão $S$. cerevisiae. $\mathrm{O}$ parental IZ 987 apresenta ainda a primeira banda cromossômica com peso molecular muito semelhante a primeira banda do padrão. Por outro lado pode-se observar que o padrão de resolução de bandas cromossômicas do parental ABXR.11B é semelhante ao padrão de $S$. cerevisiae. Gomes (1995) quando utilizou a separação de cromossomos, 
pelo método $\mathrm{CHEF}$, para proceder à identificação de leveduras da indústria cervejeira, encontrou grandes diferenças nos padrões de bandeamento principalmente quanto ao número de bandas obtidas. O número de bandas foi de $4,6,14$ ou 18 , de acordo com a linhagem. Os resultados obtidos por Gomes (1995) demonstram a grande diversidade de leveduras utilizadas na indústria cervejeira.

Tabela 9 - Pesos moleculares dos parentais ABXR.11B e IZ 987, produto de fusão 67 e recombinante $15 \mathrm{~S}$.

\begin{tabular}{|c|c|c|c|c|c|c|c|c|c|c|}
\hline \multirow[t]{2}{*}{$\begin{array}{c}\text { Bandas } \\
\mathrm{n}^{2}\end{array}$} & \multicolumn{2}{|c|}{$\begin{array}{c}\text { Padrão } \\
\text { S. cerevisiae } \\
\end{array}$} & \multicolumn{2}{|c|}{ ABXR.11B } & \multicolumn{2}{|c|}{ IZ 987} & \multicolumn{2}{|c|}{ PF 67} & \multicolumn{2}{|c|}{$15 \mathrm{~S}$} \\
\hline & $\begin{array}{c}\text { Peso } \\
\text { Molecular } \\
\text { (Mb) }\end{array}$ & $\begin{array}{l}\mathrm{Rf} \\
(\mathrm{cm})\end{array}$ & $\begin{array}{c}\text { Peso } \\
\text { Molecular } \\
\text { (Mb) }\end{array}$ & $\begin{array}{l}\mathrm{Rf} \\
(\mathrm{cm})\end{array}$ & $\begin{array}{c}\text { Peso } \\
\text { Molecular } \\
(\mathbf{M b})\end{array}$ & $\begin{array}{l}\mathrm{Rf} \\
(\mathrm{cm})\end{array}$ & $\begin{array}{c}\text { Peso } \\
\text { Molecular } \\
\text { (Mb) }\end{array}$ & $\begin{array}{l}\mathrm{Rf} \\
(\mathrm{cm})\end{array}$ & $\begin{array}{c}\text { Peso } \\
\text { Molecular } \\
\text { (Mb) }\end{array}$ & $\begin{array}{l}\mathrm{Rf} \\
(\mathrm{cm})\end{array}$ \\
\hline 1 & 2,200 & 1,15 & 2,090 & 1,25 & 2,300 & 1,05 & 2,300 & 1,05 & 2,300 & 1,05 \\
\hline 2 & 1,125 & 2,60 & 1,125 & 2,60 & 2,090 & 1,25 & 2,090 & 1,25 & 2,090 & 1,25 \\
\hline 3 & 1,020 & 3,45 & 1,090 & 2,90 & 1,900 & 1,45 & 1,900 & 1,45 & 1,900 & 1,45 \\
\hline 4 & 0,945 & 3,65 & 1,050 & 3,40 & 1,750 & 1,65 & 1,750 & 1,65 & 1,750 & 1,65 \\
\hline 5 & 0,850 & 4,30 & 0,940 & 3,85 & 1,250 & 2,40 & 1,250 & 2,40 & 1,250 & 2,40 \\
\hline 6 & 0,800 & 4,55 & 0,800 & 4,55 & 1,125 & 2,60 & 1,125 & 2,60 & 1,125 & 2,60 \\
\hline 7 & 0,770 & 4,80 & 0,710 & 5,10 & & & 1,090 & 2,90 & 0,930 & 3,90 \\
\hline 8 & 0,700 & 5,15 & 0,680 & 5,40 & & & 1,050 & 3,40 & & \\
\hline 9 & 0,630 & 5,75 & 0,670 & 5,65 & & & 0,940 & 3,85 & & \\
\hline 10 & 0,580 & 6,00 & 0,600 & 5,95 & & & 0,800 & 4,55 & & \\
\hline 11 & 0,460 & 6,70 & 0,450 & 6,80 & & & 0,710 & 5,10 & & \\
\hline 12 & 0,370 & 7,45 & 0,375 & 7,40 & & & 0,680 & 5,40 & & \\
\hline 13 & 0,290 & 7,70 & 0,310 & 7,65 & & & 0,670 & 5,65 & & \\
\hline 14 & 0,245 & 7,90 & 0,215 & 8,05 & & & 0,600 & 5,95 & & \\
\hline 15 & & & & & & & 0,450 & 6,80 & & \\
\hline 16 & & & & & & & 0,375 & 7,40 & & \\
\hline 17 & & & & & & & 0,310 & 7,65 & & \\
\hline 18 & & & & & & & 0,215 & 8,05 & & \\
\hline
\end{tabular}

Quando se observa os dados de separação de DNA cromossômico de várias espécies de leveduras através do método OFAGE, obtidos por Jonge et al.(1986), pode-se visualizar a grande diferença de padrões de bandas entre os diferentes gêneros e as diferentes espécies. Por outro lado, pode-se observar uma diversidade no padrão eletroforético entre linhagens da mesma espécie mas com um aspecto similar de número $\mathrm{e}$ posicionamento das bandas. 


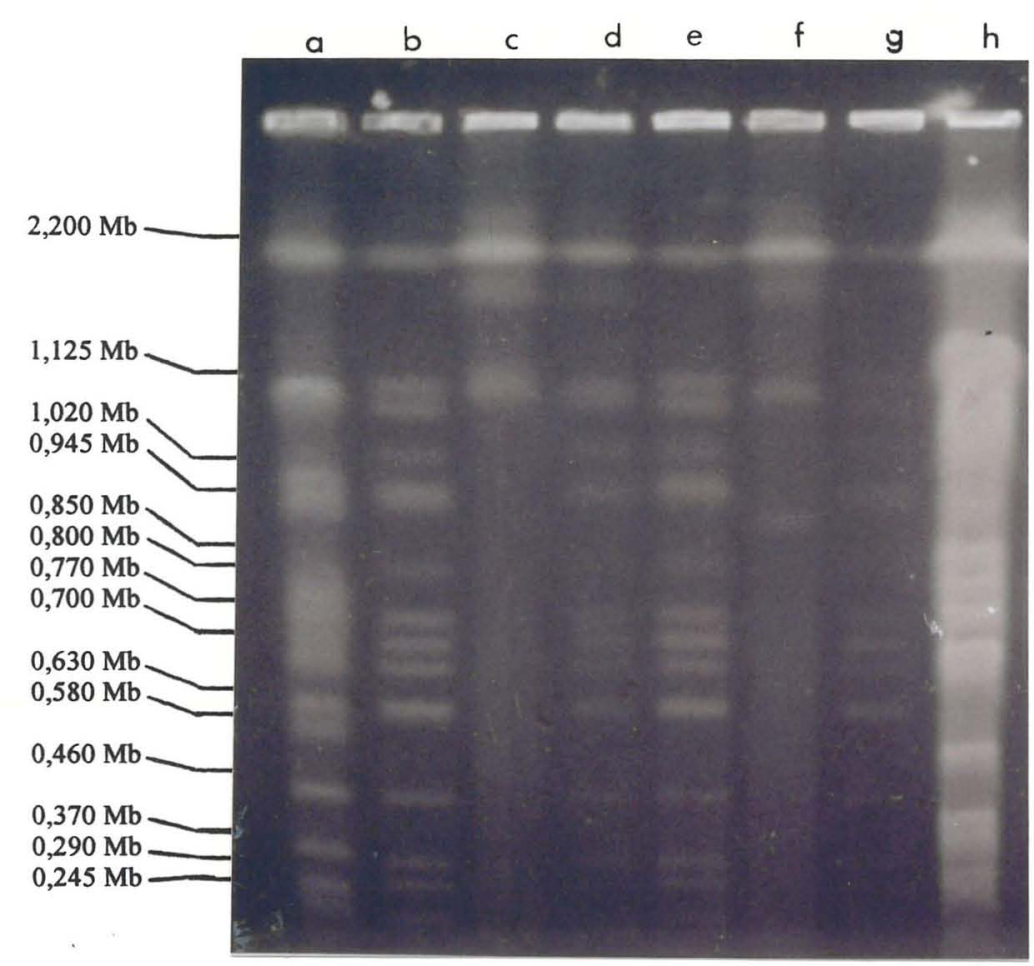

Figura 11 - Resolução de bandas cromossômicas das linhagens parentais, dos seus produtos de fusão e dos segregantes. (a) padrão de Saccharomyces cerevisiae; (b) ABXR.11B; (c) IZ 987; (d) PF67; (e) 26S; (f) 15S; (g) 18S; (h) PF70.

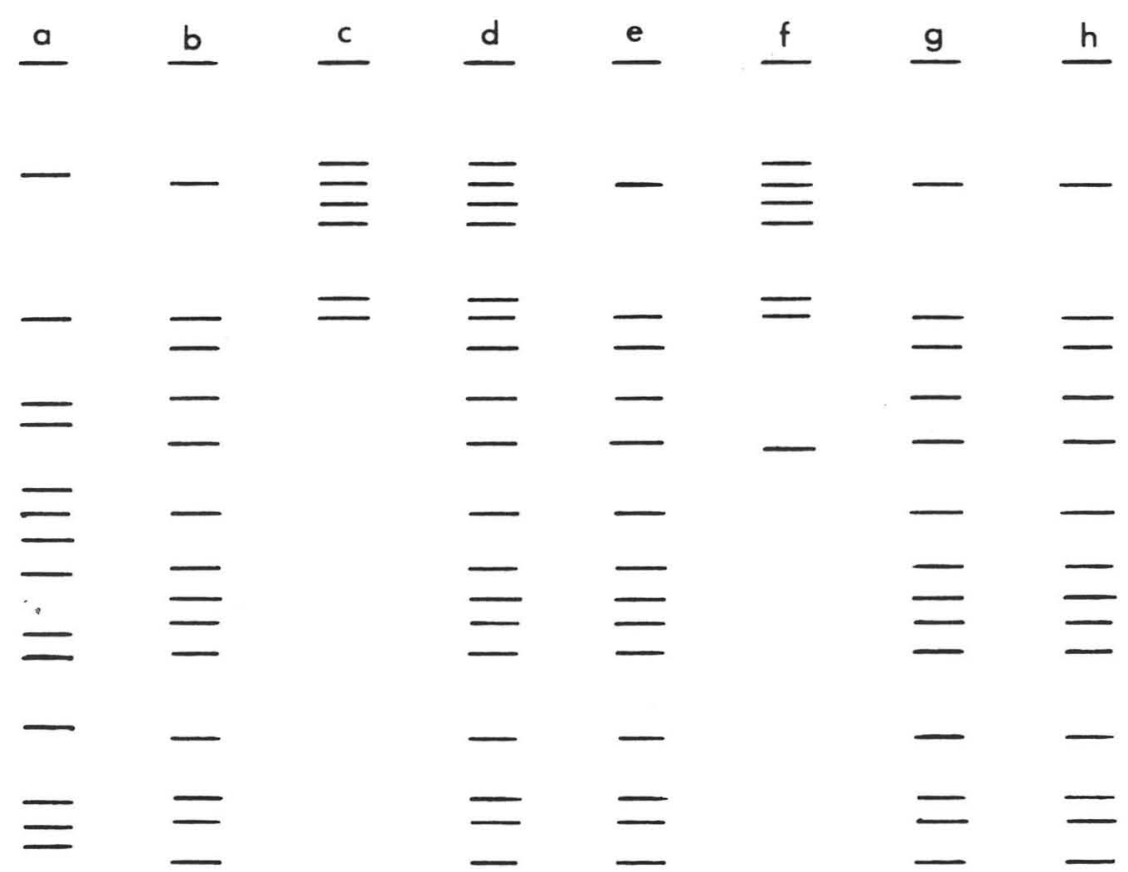

Figura 12 - Diagrama da resolução das bandas cromossômicas das linhagens parentais, dos seus produtos de fusão e dos segregantes. (a) padrão de Saccharomyces cerevisiae; (b) ABXR.11B; (c) IZ 987; (d) PF67; (e) 26S; (f) 15S; (g) 18S; (h) PF70. 
Naumov et al. (1992) investigaram a homologia genética entre 3 espécies aparentadas do gênero Saccharomyces, stricto senso, por cariotipagem eletroforética. Neste estudo concluíram que as três espécies analisadas apresentavam 16 cromossomos, e que o cariótipo eletroforético das linhagens selvagens de $S$. cerevisiae e $S$. paradoxus eram praticamente idênticos, enquanto que as linhagens de $S$. bayanus possuem cariótipos espécie-específicos.

Reforçando o trabalho anterior Hawthorne \& Philippsen (1994), ao analisarem o cariótipo eletroforético de $S$. cerevisiae, $S$. douglasii e $S$. uvarum obtido pelo método OFAGE, observaram que não houve diferença no tamanho dos cromossomos e que provavelmente o número de cromossomos fosse igual, embora reconhecessem a dificuldade para separar os cromossomos longos.

Os estudos acima expostos indicam possivelmente que as diferenças nos padrões de bandas obtidas pela separação do DNA cromossômico das linhagens ABXR.11B e IZ 987 sejam oriundas de uma grande distância taxonômica entre estas linhagens, o cariótipo eletroforético da linhagem ABXR.11B se assemelha aos de Saccharomyces cerevisiae, enquanto que o da linhagem IZ 987 sugere outro gênero.

$O$ fato da linhagem IZ 987 provavelmente pertencer a outro gênero pode explicar alguns dados obtidos, como: curva de crescimento da linhagem IZ 987 diferente do esperado para $S$. cerevisiae, taxa de fusão de protoplasto muito baixa, alta instabilidade dos produtos de fusão.

Foi realizada a separação do DNA cromossômico para comprovar a ocorrência da fusão dos protoplastos e para investigar a natureza cromossômica dos segregantes. As características das linhagens selecionadas para este estudo estão relacionadas na Tabela 10. Enquanto que os resultados obtidos estão apresentados na Figura 11 e sua representação esquemática na Figura 12. 
Tabela 10 - Características das linhagens selecionadas para estudos de cariotipagem eletroforética e RAPD.

\begin{tabular}{cccc}
\hline Linhagem & Observação & Floculante & $\mathrm{H}_{2} \mathrm{~S}$ \\
\hline ABXR.11B & Parental 1 & + & + \\
IZ987 & Parental 2 & - & - \\
PF67 & Produto de Fusão & + & + \\
PF70 & Produto de Fusão & + & - \\
26S & Segregante & + & - \\
$15 \mathrm{~S}$ & Segregante & - & $+/-$ \\
$18 \mathrm{~S}$ & Segregante & + & + \\
\hline
\end{tabular}

(+) indica presença da característica; (-) indica ausência da característica.

Pode-se observar que o produto de fusão 67 (PF67) apresenta uma complementaridade das bandas, enquanto que os segregantes de um produto de fusão (26S e 18S) apresentam o mesmo padrão do parental ABXR.11B, apesar do segregante 26S apresentar a característica $\mathrm{H}_{2} \mathrm{~S}^{*}$ e do segregante 18S apresentar um fenótipo intermediário quanto a produção de $\mathrm{H}_{2} \mathrm{~S}$ (pequena produção de $\mathrm{H}_{2} \mathrm{~S}$ ). Por outro lado o segregante $15 \mathrm{~S}$ apresenta um padrão de separação do DNA cromossômico intermediário, com todas as bandas do parental IZ 987 mais uma banda de peso molecular $(0,950 \mathrm{Mb})$ diferente do parental ABXR.11B.

A banda de peso molecular de $0,950 \mathrm{Mb}$ que aparece no segregante $15 \mathrm{~S}$, pode ter sido originada por perda de um pedaço do cromossomo durante uma permuta mitótica entre os núcleos fusionados. Heluane et al. (1993) ao procederem a separação dos cromossomos de híbridos obtidos por fusão de protoplastos entre Pachysolen tannophilus e Saccharomyces cerevisiae, verificaram que os produtos de 
fusão apresentaram genomas alterados em relação aos parentais. Esta alteração foi constatada pela presença de 4 bandas como no primeiro parental mas com mobilidade de 3 bandas maiores que a do referido parental.

\subsection{Polimorfismo de DNA amplificado ao acaso - RAPD}

Para a reação de RAPD foi isolado o DNA das linhagens especificadas na Tabela 10. Inicialmente 5 primers (OPB-10, OPB-12, OPB-17, OPX-10, OPX-16) foram testados, sendo 2 selecionados por permitirem a amplificação do DNA e a geração de polimorfismo entre as linhagens. Dos 5 primers 3 (OPB-10, OPB-12, OPB-17) já haviam sido selecionados por Gomes (1995) para a amplificação de fragmentos de DNA em leveduras da indústria alcooleira e cervejaria.

As reações de RAPD foram realizadas como descrito no item $3.15 .2 \mathrm{e}$ com a utilização dos dois primers, foi obtido um padrão de amplificação de fragmentos de DNA para as linhagens sob estudo como demonstrado na Figura 13. Os 2 primers selecionados produziram 11 bandas polimórficas, sendo que a análise conjunta conjunta dos produtos de amplificação desses primers permitiu a construção de uma matriz de similaridade e posteriormente a elaboração de um dendrograma de similaridade genética entre os parentais, produtos de fusão e alguns segregantes (Figura 14). 

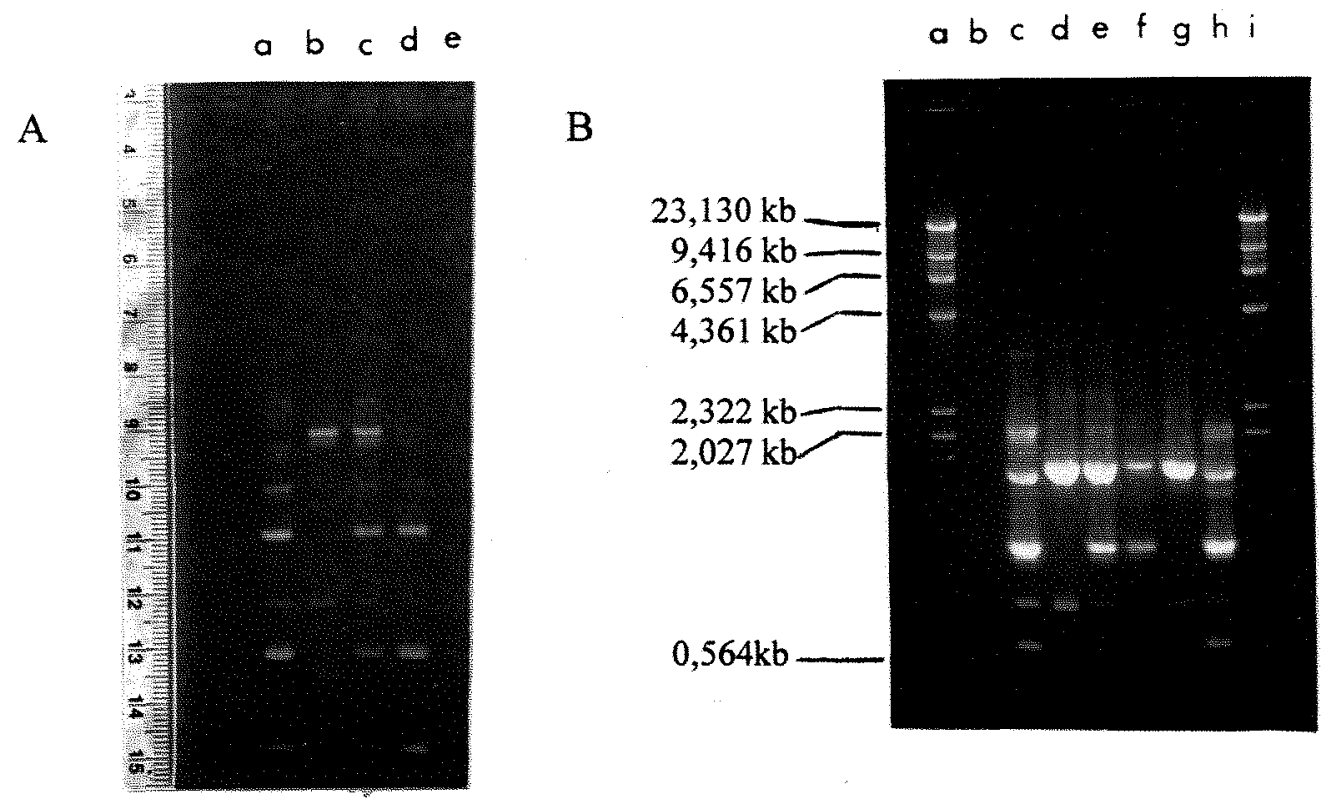

Figura 13 - Padrão de amplificação de fragmentos de DNA. (A) OPB-12: (a) ABXR.11B, (b) IZ 987, (c) PF67, (d) PF70, (e) branco; (B) OPX-10: (a) marcador de peso molecular, (b) branco, (c) ABXR.11B, (d) IZ 987, (e) PF67, (f) 18S, (g) 15S, (h) PF70, (i) marcador de peso molecular.

Com base nos dados da Figura 13 constata-se que o produto de fusão PF67 é um híbrido pois apresenta um padrão de bandas complementar entre os parentais. Este tipo de resultado foi obtido por Francis \& Clair (1993) quando procederam à identificação da progênie de cruzamentos de linhagens de Pythium ultimum. Este autores identificaram os híbridos da $F_{1}$ por complementação de bandas. Obtiveram uma banda bem definida em cada parental, enquanto que os hibridos apresentaram ambas. Verifica-se que o PF70 apresenta um padrão de amplificação idêntico ao parental ABXR.11B. Enquanto que pelo padrão de amplificação obtido com o primer OPX-10 (Figura 15 B), verifica-se que a linhagem $15 \mathrm{~S}$ segregou ao parental IZ 987 e o segregante $18 \mathrm{~S}$ apresenta um novo padrão. 


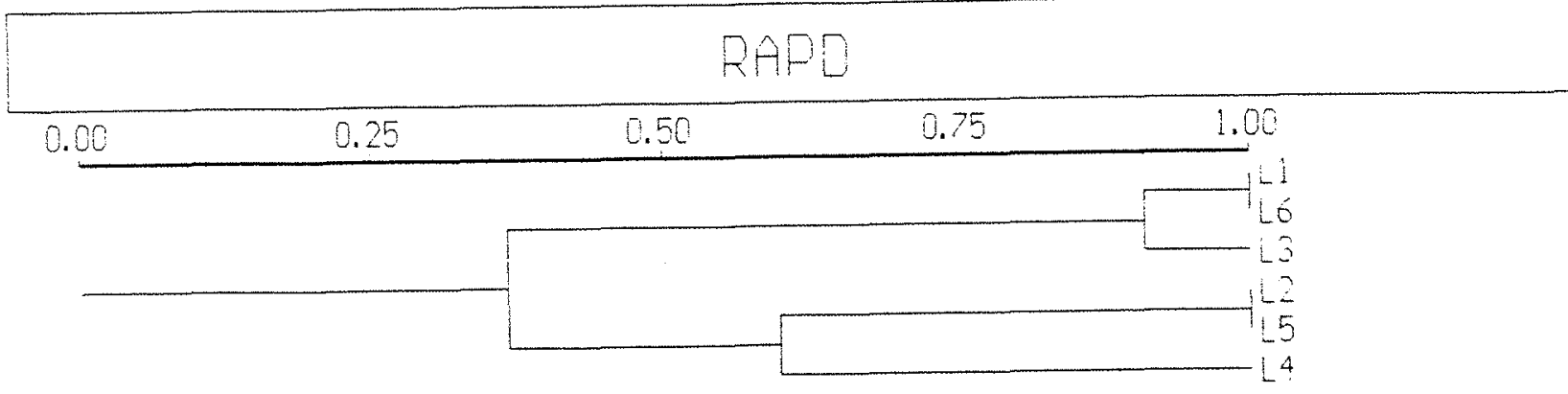

Figura 14 - Dendrograma obtido a partir da matriz de similaridade genética entre linhagens parentais, seus produtos de fusão e segregantes, a partir de dados obtido pelo método RAPD, onde L1- parental ABXR.11B; L2parental IZ 987; L3- PF67; L4- segregante 18S; L5- segregante 15S; L6PF70.

Gomes (1995) ao comparar métodos de identificação de leveduras, constatou que o RAPD é o método mais sensível e mais eficiente na identificação de linhagens muito semelhantes, as quais apresentam alto coeficiente de similaridade. Partindo destas observações pode-se sugerir que o baixo coeficiente de similaridade observado entre os parentais aponta para uma grande distância taxonômica entre eles, reforçando a hipótese de a linhagem não pertencer ao gênero Saccharomyces. 


\section{CONCLUSÕES}

Os resultados obtidos no presente trabalho permitem concluir que:

- Por fusão de protoplastos é possível obter linhagens de leveduras altamente floculantes e não produtoras de $\mathrm{H}_{2} \mathrm{~S}$. A técnica de fusão de protoplastos permitiu a obtenção de novos genótipos recombinantes a partir de linhagens com grande distanciamento taxonômico, como ocorrido entre as linhagens ABXR.11B e IZ 987.

- Os genótipos recombinantes foram obtidos pela alta instabilidade dos produtos de fusão, nos quais as características de floculação e não produção de $\mathrm{H}_{2} \mathrm{~S}$ expressaram-se numa só linhagem.

- A linhagem IZ 987 pode até não pertencer ao gênero Saccharomyces, pois o perfil do cariótipo eletroforético foi muito diferente de todos os cariótipos obtidos e apresentados pela literatura para este gênero. $O$ baixo coeficiente de similaridade observado através do dendrograma obtido pelos dados do RAPD, também aponta para este fato. 


\section{REFERÊNCIAS BIBLIOGRÁFICAS}

AMERINE, M. A.; CRUESS, W. V. The technology of wine making. Westport: The Avi Publishing Company, Inc., 1960. 709p.

AMRI, M. A.; BONALY, R.; DUTEURTRE, B.; MOLL, M. Yeast flocculation: influence of nutritional factors on cell wall composition. Journal of General Microbiology,v.128, p.2001-2009, 1982.

ANJANI-KUMARI, J.; PANDA, T. Intergeneric hybridization of Trichoderma reesei QM9414 and Saccharomyces cerevisiae NCIM 3288 by protoplast fusion. Enzyme and Microbial Technology, v.16, n.10, p.870-882, 1994.

ANNÉ, J.; PEBERDY, J. F. Induced fusion of fungal protoplasts following treatment with polyethylene glicol. Journal of General Microbiology, v.92, p.413-417, 1976.

ATKINSON, B.; DAUOD, I. S. Microbial flocs and flocculation in fermentation process engineering. In: GHOSE, T. K.; FIECHTER, A.; BLAKEBROUGH, N. (Ed.) Advances in Biochemical Engineering. Berlin: Springer-Verlag, 1976. v.4, p.41124.

AZEVEDO, J. L. Genética fisiológica e de microorganismos. ESALQ, Departamento de Genética, Piracicaba, 1972. 490p. 
BASSO, L. C.; AMORIM, H. V.; OLIVEIRA, A. J. Acompanhamento e seleção de leveduras do processo pela técnica da cariotipagem. Piracicaba: USP/ESALQ, Depto. Química/ FERMENTEC, 1995. p.1-6. (Relatório Anual de Pesquisas em Fermentação Alcoólica n̊ 15)

BASSO, L. C.; AMORIM, H. V.; OLIVEIRA, A. J.; ORELLI, V. F. D. M. Identificação de leveduras pela técnica da eletroforese do DNA cromossomico (cariotipagem). Piracicaba: USP/ESALQ, Depto. Química/ FERMENTEC, 1992. p.101-110. (Relatório Anual de Pesquisas em Fermentação Alcoólica $\mathrm{n}^{0}$ 12)

BELLIS, M.; PAGĖS, M.; ROIZÈS, G. A simple and rapid method for preparing yeast chromosomes for Pulse Field Gel Electrophoresis. Nucleic Acids Research. v.15, n.16, p.6749, 1987.

BIELECKI, S.; BRZESKI, H. Characterization of non-flocculent cells isolated from a culture of flocculent Saccharomyces cerevisiae NCYC 1001. FEMS Microbiology Letters, v.61, p.189-194, 1989.

BOYD, W. D.; SHAPLEIGH, E. Specific precipitating activity of plant agglutinins (lectins). Science, v.119, p.419, 1954.

BROMBERG, R. Estudo do mecanismo de floculação de leveduras causadas por Lactobacillus fermentum. Campinas, 1994. 74p. Tese (Mestrado) - Faculdade de Engenharia de Alimentos / Universidade de Campinas.

BURNETT, J. H. Mycogenetics. London: J. Wiley \& Sons. 1975. 375p.

CALLEJA, G. B. Cell agregation. In: ROSE, A. H.; HARRISON, J. S. (Ed.) The yeasts. 2.ed. London: Academic Press, 1987. vol.2, p.165-238. 
CARDINALI, G; MARTINI, A. Electrophoretic karyotypes of authentic strains of the sensu stricto group of the genus Saccharomyces. International Journal of Systematic Bacteriology, v.44, n.4, p.791-797, Oct. 1994.

CARLE, G. F.; OLSON, M. V. Separation of chromossomal DNA molecules from yeast by orthogonal-field-alternation gel electrophoresis. Nucleic Acids Research, v.12, n.14, p.5647-5664, 1984.

CARLE, G. F.; OLSON, M. V. An electrophoretic karyotype for yeast. Proceedings of the National Academy of Sciences USA, v.82, p.3756-3760, Jun. 1985.

CARRAU, J. L.; AZEVEDO, J. L.; SUDBERY, P.; CAMPBELL, D. Methods for recovering fusion products among oenological strains of Saccharomyces cerevisiae and Schizosaccharomyces pombe. Revista Brasileira Genética, v.5, n.1, p.221$226,1982$.

CARRAU, J. L. A fusão de esferoplastos como nova ferramenta para o desenvolvimento de leveduras de vinificação. In: AZEVEDO, J. L. (Coord.) Genética de microrganismos em biotecnologia e engenharia genética. Piracicaba: FEALQ, 1985. cap.II.15, p.115-120.

COUTO, M. M. B.; VOGELS, J. T. W. E.; HOFSTRA, H.; HUIS, J. H. J. Random amplified polymorphic DNA and restriction enzyme analysis of PCR amplified rDNA in taxonomy: two identification techniques for food-borne yeasts. Journal of Applied Bacteriology, v.79, p.525-535, 1995.

COUTO, M. M. B.; EIJSMA, B.; HOFSTRA, H.; VELT, J. H. J. H. in't; VOSSEN, J. M. B. M. van der. Evaluation of molecular typing techniques to assign genetic 
diversity among Saccharomyces cerevisiae strains. Applied and Environmental Microbiology, v. 62, n.1, p.41-46, 1996.

CUBETA, M. A.; BRIONES-ORTEGA, R.; VILGALYS, R. Reassessment of heterokarion formation in Rhizoctonia solani anastomosis group 4. Mycologia, v.85, n.5, p.777-787, 1993.

DAUDT, C. E.; ALMEIDA, P. Fabricação de vinhos por leveduras nativas selecionadas no Rio Grande do Sul e por Saccharomyces cerevisiae "Montrachet". Revista Centro de Ciências Rurais, v. 12, n.1, p.21-27, 1982.

DEGRÉ, R.; THOMAS, D. Y.; ASH, J.; MAILHIOT, K.; MORIN, A.; DUBORD, C. Wine yeasts strain identification. American Journal of Enology and Viticulture, v.40, n.4, p.309-315, 1989.

DUNWELL, J. L.; AHMAD, F.; ROSE, A. H. Changes in the polysaccharide composition of yeast resulting from biotin deficiency. Biochimica et biophysica acta, v.51, p.604-607, 1961.

DURAND, N.; REYMOND, P.; FÈVRE, M. Randomly amplified polymorphic DNAs asses recombination following an induced parasexual cycle in Penicillium roqueforti. Current Genetics, v.24, p.417-420, 1993.

EDDY, A. A. Flocculation characteristics of yeasts I. Comparative survey of various strains of Saccharomyces cerevisiae. Journal of the Institute of Brewing, v.61, p.307-312, 1955.

ESCHENBRUCH, R.; BONISH, P. Production of sulphite and sulphide by low- and high-sulphite forming wine yeasts. Archives of Microbiology, v.107, p.299-302, 1976. 
ESSER, K. \& KÜES, U. Flocculation and its implication for biotechnology. Process Biochemistry, v.18, p.21-23, 1983.

EVANS, I. H.; DIALA, E. S.; EARL, A.; WILKIE, D. Mitochondrial control of cell surface characteristics in Saccharomyces cerevisiae. Biochimica et biophysica acta, v.602, p.201-206, 1982.

FARAHNAK, F.; SEKI, T.; DEWEY, D. Y. R.; OGRYDZIAK, D. Construction of lactose-assimilating and high-ethanol-producing yeasts by protoplast fusion. Applied and Environmental Microbiology, v.51, n.2, p.362-367, Feb. 1986.

FERENCZY, L.; KEVEI, F.; ZSOLT, J. Fusion of fungal protoplasts. Nature, v.248, p.793-794, 1974.

FERENCZY, L. Protoplast fusion in yeasts. In: PEBEERDY, J. F.; FERENCZY, L. (Ed.) Fungal protoplasts: applications in biochemistry and genetics. New York: Marcel Dekker, Inc, 1985. v.6, cap.14, p.279-306.

FINCHAM, J. R. S.; DAY, P. R.; RADFORD, A. Fungal genetics. 4.ed. Oxford: Blackwell Scientific Publications, 1979. 636 p.

FISHER, D. J. Flocculation: some observations on the surface charges of yeast cells. Journal of the Institute of Brewwing, v.81, p.107-110, 1975.

FOUNIER, P.; PROVOST, A.; BOURGUIGNON, C. ; HESLOT, H. Recombination after protoplast fusion in the yeast Candida tropicalis. Archives of Microbiology, v.115, p.143-149, 1977. 
FRANCIS, D. M.; CLAIR, D. A. St. Outcrossing in the homothallic oomycete, Pythium ultimum, detected with molecular markers. Current Genetics, v.24, p.100-106, 1993.

FREZIER, V.; DUBOURDIEU, D. Ecology of yeast strain Saccharomyces cerevisiae during spontaneous fermentation in a Bordeaux winery. American Journal of Enology and Viticulture, v.43, n.4, p.375-380, 1992.

FUNGARO, M. H. P.; PIZZIRANI-KLEINER, A. A. Isolation of auxotrophic mutants of Candida tsukubaensis. Revista de Microbiologia, v.23, n.2, p.101-105, 1992.

FUNGARO, M. H. P.; AZEVEDO, J. L.; PIZZIRANI-KLEINER, A. A. Genetic recombination after protoplast fusion in Candida sp. Revista Brasileira de Genética, v.15, n.3, p.499-507, 1992.

GIUDICI, P.; KUNKEE, E. The effect of nitrogen deficiency and sulfur-containing amino acids on the reduction of sulfate to hydrogen sulfide by wine yeasts. American Journal of Enology and Viticulture, v.45, n.1, p.107-112, 1994.

GILLY, J. A.; SANDS, J. A. Electrophoretic kayotype of Trichoderma reesei. Biotech nology Letters, v.13, n.7, p.477-482, 1991.

GOMES, L. H. Avaliação de quatro métodos para a identificação de leveduras. Piracicaba, 1995. 88 p. Dissertação (Mestrado) - Escola Superior de Agricultura “Luiz de Queiroz"/Universidade de São Paulo.

GOMES, L. H.; ARGUESO, J. L.; DUARTE, K. M. R.; TAVARES, F. C. A. RAPD para identificação leveduras industriais. In: REUNIÃO ANUAL DE GENÉTICA DE MICRORGANISMOS, 20, Piracicaba, 1995. Anais. Piracicaba: ESALQDepto. de Genética, 1995. p.154. 
GUPTHAR, A. S. Segregation of altered parental properties in fusions between Saccharomyces cerevisiae and D-xylose fermenting yeasts Candida shehatae and Pichia stipitis. Canadian Journal of Microbiology, v.38, p.1233-1237, 1992.

GUNGE, N. \& TAMARU, A. Genetic analysis of products of protoplast fusion in Saccharomyces cerevisiae. Japanese Journal of Genetics, v.53, n.1, p.41-49, 1978.

HAECHT, J. L. van; DUFOUR, J. P. The production of sulfur compounds by brewing yeast: a review. Cerevisia and Biotechnology, v.20, n.1, p.51-64, 1995.

HAMLYM, P. F.; BRADSHAW, R. E.; MELLON, F. M.; SANTIAGO, C. M.; WILSON, J. M.; PEBERDY, J. F. Efficient protoplast isolation from fungi comercial enzymes. Enzyme and Microbial Technology, v.3, p.321-325, 1981.

HAMMOND, J. R. M. Brewer's yeasts. In: ROSE, A. H.; HARRISON, J. S. (Ed.) The Yeasts. London: Academic Press, 1993. v.5, cap.2, p.7-67.

HAMMOND, J. R. M. Genetically-modified brewing yeast for the 21st century. Progress to Date. Yeast, v.11, p.1613-1627, 1995.

HARRIS, R. H.; MITCHELL, R. The role of polymers in microbial aggregation. Annual Reviews Microbiology, v.27, p.27-50, 1973.

HAWTHORNE, D. \& PHILIPPSEN, P. Genetic and molecular analysis of hybrids in the gennus Saccharomyces involving $S$. cerevisiae, $S$. uvarum and a New species, $S$. douglasii. Yeast. v.10, p.1285-1296, 1994. 
HELUANE, H.; SPENCER, J. F. T.; SPENCER, D.; FIGUEROA, L. de; CALLIERI, D. A. S. Characterization of hybrids obtained by protoplast fusion, between Pachysolen tannophilus and Saccharomyces cerevisiae. Applied Microbiology and Biotechnology, v.40, p.98-100, 1993.

HINCHLIFFE, E.; KENNY, E. Yeast as a vehicle for the expression of heterologous genes. In: ROSE, A. H. \& HARRISON, J. S. (Ed.) The Yeasts. London: Academic Press, 1993. v.5, cap.9, p.325-356.

HINRICHS, R. H.; STAHL, U.; ESSER, K. Flocculation of Saccharomyces cerevisiae and mitochondrial DNA structure. Applied Microbiology and Biotechnology, v.29, p.48-54, 1988.

HOUGH, J. S.; BRIGGS, D. E.; STEVENS, R. Malting Brewing \& Science. London: Chapman and Hall Ltda, 1971.

HOUGH, J. S.; BRIGGS, D. E.; STEVENS, R.; YOUNG, T. W. Malting Brewing and Science: Hopped wort and beer. 2.ed. London; New York: Chapman and Hall, 1982. cap.3, p.566-614: Metabolism of wort by yeast.

IBEAS, J. I.; JIMENEZ, J. Electrophoretics karyotype of budding yeasts with intact cell wall. Nucleic Acids Research, v.21, n.16, p.3902, 1993.

JAVADEKAR, V. S.; SIVARAMAN, H.; GOKHOLE, D. V. Industrial yeast strain improvement: construction of a highly flocculent yeast with a killer character by protoplast fusion. Journal of Industrial Microbiology, v.15, n.2, p.94-102, 1995.

JAYATISSA, P. M. \& ROSE, A. H. Role of wall phosphomannan in flocculation of Saccharomyces cerevisiae. Journal of General Microbiology, v.96, p.165-174, 1976. 
JIRANEK, V.; LANGRIDGE, P.; HENSCHKE, P. A. Regulation of hydrogen sulfide liberation in wine-producing Saccharomyces cerevisiae strains by assimilable nitrogen. Applied and Environmental Microbiology, v.61, n.2, p.461-467, Feb. 1995a.

JRANEK, V.; LANGRIDGE, P.; HENSCHKE, P. A. Validation of bismuth-containing indicator media for predicting $\mathrm{H}_{2} \mathrm{~S}$-producing potential of Saccharomyces cerevisiae wine yeasts under enological conditions. American of Enology and Viticulture, v.46, n.2, p.269-273, 1995 b.

JOHNSON, B. F.; WALKER, T.; CALLEJA, G. B.; SELIGY, V. L. Sexual coflocculation and assexual self-flocculation in budding and fission yeasts: experimental establishment of a fundamental difference. Canadian Journal of Microbiology, v.34, p.1105-1107, 1988.

JOHNSTON, J. R. Pulsed field gel electrophoresis. In: JOHNSTON, J. R. (Ed.) Molecular genetics of yeast: a practical approach. Oxford: Oxford University Press, 1994. cap.5, p.83-95.

JOHNSTON, J. R.; MORTIMER, R. K. Electrophoresis karyotyping of laboratory and commercial strains of Saccharomyces and other yeasts. International Journal of Systematic Bacteriology, v.36, n.4, p.569-572, Oct. 1986.

JOHNSTON, J. R.; CONTOPOULOU, C. R.; MORTIMER, R. K. Karyotyping of yeast strains of several genera by field inversion gel electrophoresis. Yeast, v.4, p.191$198,1988$. 
JONGE, P.; JONGH, F. C. M. de; MEIJERS, R.; STEENSMA, H. Y.; SCHEFFERS, W. A. Orthogonal-field-alternation gel electrophoresis banding patterns of DNA from yeasts. Yeast, v.2, p.193-204, 1986.

KAMADA, K.; MURATA, M. On the mechanism of brewer's yeast flocculation. Agriculture and Biological Chemistry, v.48, n.10, p.2423-2433, 1984.

KIHN, J. C.; MASY, C. L.; MESTDAGH, M.M. Yests flocculation: competition between nonspecific repulsion and specific bonding in cell adhesion. Canadian Journal of Microbiology, v.34, p.1105-1107, 1988.

KODAMA, K. Saké-brewing yeasts. In: ROSE, A. H.; HARRISON, J. S. (Ed.) The Yeasts: Yeast technology. London: Academic Press, 1993. v.5, cap.4, p.129-198.

KRUYT, H. R. General introduction. In: KRUYT, H. R. (Ed.) Colloid science. Amsterdam: Elsevier Publishing Co., 1952. p. 1-57.

KUNKEE, R. E.; AMERINE, M. A. Yeasts in wine-making. In: ROSE, A. H.; HARRISON, J. S. (Ed.) The Yeasts. London: Academic Press, 1970. v.3, cap. 2, p.4-71.

KUNKEE, R. E.; BISSON, L. F. Wine-making yeasts. In: ROSE, A. H.; HARRISON, J. S. (Ed.) The Yeasts: Yeast technology. London: Academic Press, 1993. v.5, cap.3, p.69-127.

LAGE, A. A. Elaboração de vinhos brancos. Rio de Janeiro: Ministério da Agricultura Serviço de Informação Agrícola, 1962. 136p.

LEDERBERG, J. \& LEDERBEG, E. M. Replica plating and indirect selection of bacterial mutants. Journal of Bacteriology, v.63, p.390-406, 1952. 
LEE, J. H.; SKOTNINKI, M. L.; ROGERS, P. L. Kinetic studies on a flocculent strain of Zymomonas mobilis. Biotechnology Letters, v.4, n.9, p.615-621, 1982.

LEWIS, C. W.; JOHNSTON, J. R.; MARTIN, P. A. The genetics of yeast flocculation. Journal of the Institute of Brewing, v.82, p.158-160, 1976.

LYONS, T. P. ; HOUGH, J. S. Flocculation of brewer's yeast. Journal of the Institute of Brewing, v.76, p.564-571, 1970.

MANULIS, S.; KOGAN, N. REUVEN, M.; BEN-YEPHET, Y. Use of the RAPD technique for identification of Fusarium oxysporum f. sp. dianthi from carnation. Phytopathology, v.84, p.98-101, 1994.

McCLUSKEY, K.; RUSSEL, B. W.; MILLS, D. Electrophoretic karyotyping without the need for generating protoplasts. Current Genetics, v.18, p.385-386, 1990.

MIKI, B. L. A.; PONN, N. H.; JAMES, A. P.; SELIGY, V. L. Possible mechanism for flocculation interactions governed by gene FLO1 in Saccharomyces cerevisiae. Journal of Bacteriology, v.150, n.2, p.878-889, May 1982.

MILL, P. J. The effect of nitrogenous substances on the time of flocculation of Saccharomyces cerevisiae. Journal of General Microbiology, v.35, p.53-60, 1964a.

MILL, P. J. The nature of interactions between flocculent cells in the flocculation of Saccharomyces cerevisiae. Journal of General Microbiology, v.35, p.61-68, 1964b. 
MILL, P. J. Phosphomannans and other components of flocculent and non-flocculent walls of Saccharomyces cerevisiae. Journal of General Microbiology, v.44, p.329-341, 1966.

MORTIMER, R. K. \& HAWTHORNE, D. C. Yeast genetics. In: ROSE, A. H. \& HARRISON, J. S., ed. The yeasts. New York: Academic Press, 1969. vol. 1, p. $385-460$.

NAUMOV,G.; NAUMOVA, E. S.; LANTTO, R. A.; LOUIS, E. J.; KORHOLA, M. Genetic homology between Saccharomyces cerevisiae and its sibling species $S$. paradoxus and S. bayanus: electrophoretic karyotypes. Yeast, v.8, p.599-612, 1992.

NETTO, C. B.; DESTRUHAUI, A.; GOMA, G. Ethanol fermentation by flocculating yeast: performance and stability dependence on a critical fermentation rate. Biotechnology Letters, v.7, n.5, p.355-360, 1985.

NICKERSON. W. J. Reduction of inorganic substances by yeasts. I: Extracellular reduction of sulfite by species of Candida. Journal of Infectious Diseases, v.93, p.43-56, 1953.

NISHIHARA, H.; TORAYA, T.; FUKUI, S. Induction of floc-forming ability in brewer's yeast. Journal of Fermentation Technology, v.54, n.6, p.356-360, 1976.

NISHIHARA, H.; TORAYA, T.; FUKUI, S. Flocculation of cell walls of brewer's yeast and effects of metal ions, protein-denaturants and enzyme treatments. Archives of Microbilogy, v.131, p.112-115, 1982.

O'BRIEN, S. J. (Ed.) Genetic maps: Locus maps of complex genomes. 5.ed. New York: Cold Spring Harbor Laboratory Press, 1990. 
PARISH, M. E.; CARROL, D. E. Fermentation characteristics of Saccharomyces cerevisiae isolates from Vitis rotundifolia grapes and musts. American Journal of Enology and Viticulture, v.38, n.1, p.45-8, 1987.

PATEL, G. B.; INGLEDEW, W. M. The relationship of acid-soluble glycogen to yeast flocculation. Canadian Journal of Microbiology, v.21, p.1608-1613, 1975.

PEYNAUD, E. El gusto del vino. Madrid: Mundi-Prensa, 1987.239p.

PONTECORVO, G.; ROPER, J. A.; HEMMONS, L. M.; MacDONALD, K. D.; BUFTON, A. W. J. The genetics of Aspergillus nidulans. Advances in Genetics, New York, v.5, p.141-238, 1953.

POWELL, W. A.; KISTLER, H. C. In vivo rearrangement of foreign DNA by Fusarium oxysporum produces linear self-replicating plasmids. Journal of Bacteriology, v.172, p.3163-3171, 1990.

PRINCE, I. G.; BARDFORD, J. P. Induced flocculation of yeasts for use in the tower fermenter. Biotechnology Letters, v.4, n.10, p.621-626, 1982.

QUESADA, M. P.; CENIS, J. L. Use of random amplified polymorphic DNA (RAPDPCR) in the characterization of wine yeasts. American Journal of Enology and Viticulture, v.46, n.2, p.204-208, 1995.

RANKINE, B. C. Nature, origin and prevention of hydrogen sulphide aroma in wines. Journal of Science Food Agriculture, v.14, p.79-91, Feb. 1963.

REED, G.; NAGODAWITHANA, W. Technology of yeast usage in winemaking. American Journal of Enology and Viticulture, v.39, n.1, p.83-90, 1988. 
REITER, R. S.; WILLIAMS, J. G. K.; FELDMANN, K. A.; RAFALSKI, J. A.; TINGEY, S. V.; SCOLNIK, P. A. Global and local genome mapping in Arabidopsis thaliana by using recombinant inbred lines and random amplified polymorfic DNAs. Proceedings of the National Academy of Sciences USA, v.89, p.1477-1481, 1992.

RIBEIRO, C. A. F. Potencialidades de diferentes linhagens de levedura da espécie Saccharomyces cerevisiae na tecnologia de aguardente de cana. Piracicaba, 1997. 107p. Dissertação (Mestrado) - Escola Superior de Agricultura "Luiz de Queiroz" / Universidade de São Paulo.

ROMANO, P.; SOLI, M. G.; SUZZI, G.; GRAZIA, L.; ZAMBONELLI, C. Improvement of wine Saccharomyces cerevisiae strain by a breeding program. Applied and Environmental Microbiology, v.50, n.4, p.1064-1067, Oct. 1985.

ROSE, A. H. \& HARRISON, J. S. (Ed.) The Yeasts. London: Academic Press, 1970. v.3, $590 \mathrm{p}$.

ROSE, A. H. \& HARRISON, J. S. Introduction. In: ROSE, A. H. \& HARRISON, J. S. (Ed.) The Yeasts:Yeast technology. London: Academic Press, 1993. v.5, cap.1, p.1-6.

ROSE, A. P. Recent research on industrially importat strains of Saccharomyces. In: SKINNER, F. A.; PASSMORE, S. M.; DAVENPORT, R. R. (Ed.) Biology activities of yeasts. London: Academic Press, 1980. p. 103-121.

RUSSEL, I. \& STEWART, G. G. Spheroplast fusion of brewer's yeast strain. Journal of the Institute of Brewing, v.85, p.95-98, 1979. 
RUSSEL, I.; STEWART, G. G.; READER, H. P.; JOHNSTON, J. R.; MARTIN, P. A. Revised nomenclature of genes that control yeast flocculation. Journal of the Institute of Brewing, v.86, p.120-121, 1980.

SCHÜTZ, M.; KUNKEE, R. E. Formation of hydrogen sulfide from elemental sulfur during fermentation by wine yeast. American Journal of Enology and Viticulture, v.28, n.3, p. 137-144, 1977.

SHAW, D. J. Introdução à química dos colóides e de superfícies. São Paulo: Edgard Blütcher, 1975. 185p.

SHEEHAN, C. A.; WEISS, A. S.; NEWSOM, I. A.; FLINT, V.; O'DONNEL, C. D. Brewing yeast identification and chromosome analysis using high resolution CHEF gel electrophoresis. Journal of the Institute of Brewing, v.97, p.163-167, MayJun. 1991.

SPENCER, J. F. T.; SPENCER, D. M.; FIGUEROA, L. de; NOUGUES, J.-M.; HELUANE, $\mathrm{H}$. Tranfer of genes for utilization of starch ( $\mathrm{sta}$ 2) and melibiose ( $m e$ ) to industrial strains of Saccharomyces cerevisiae by single-chromosome transfer, using a karl mutant as vector. Applied Microbiology and Biotechnology, v.37, p.230-234, 1992.

STEWART, G. G. Yeast flocculation: practical implications and experimental findings. Brewer's Digest, v.50, p.42-57, Mar. 1975.

STEWART, G. G. The genetic manipulation of industrial yeast strains. Canadian Journal of Microbiology, v.27, p.973-990, 1981. 
STEWART, G. G. \& RUSSEL, I. The identification, characterization and mapping of a gene for flocculation in Saccharomyces sp. Canadian Journal of Microbiology, v.23, p.441-447, 1977.

STEWART, G. G. \& RUSSELL, I. In: POLLOCK, J. R. A. (Ed.). Brewing Science. London: Academic Press, 1981. p. 61-92 v.2.

STEWART, G. G.; RUSSEL, I. Centenary review: one hundred years of yeast research and development in the brewing industry. Journal of the Institute of Brewing, v.92, p.537-558, 1986.

STRATFORD, M. Lectin-mediated aggregation of yeasts: yeasts flocculation. Biotechnology \& Genetic Engineering Reviews, v.10, p.283-341, 1992a.

STRATFORD, M. Yeast flocculation: reconciliation of physiological and genetic viewpoints. Yeast, v.8, p.25-38, $1992 \mathrm{~b}$.

STRATFORD, M.; ASSINDER, S. Yeast flocculation: Flo1 and NewFlo phenotypes and receptor structure. Yeast, v.7, p.559-574, 1991.

STRATFORD, M.; BRUNDISH, H. M. Yeast flocculation: cationic inhibition. Yeast, v.6, p.77-86, 1990.

STRATFORD, M.; CARTER, A. T. Yeast flocculation: lectin synthesis and activation. Yeast, v.9, p.371-378, 1993.

SULO, P.; MICHALCÁKOVÁ, S.; REISER, V. Construction and properties of K1 type killer wine yeasts. Biotechnology Letters, v.14, n.1, p.55-60, 1992. 
SUZZI, G. P.; ROMANO, P.; ZAMBONELLI,C. Flocculation of wine yeasts: frequency, diferences, and stability of the character. Canadian Journal of Microbiology, v.30, p.36-39, 1984.

SVOBODA, A. Fusion of yeast protoplasts induced by polyethytene glycol. Journal of Microbiology. v.109, p.160-175, 1978.

TAYLOR, N. W. ; ORTON, W. L. Calcium in flocculence of Saccharomyces cerevisiae. Journal of the Institute of Brewing, v.81, p.53-57, 1975.

THOMAS, C. S.; BOULTON, R. B.; SILACCI, M. W.; GUBLER, W. D. The effect of elemental sulfur, yeast strain, and fermentation medium on hydrogen sulfide production during fermentation. American Journal of Enology and Viticulture, v.44, n.2, p.211-216, 1993.

VARGA, J.; CROFT, J. H. Assignment of RFLP, RAPD and isoenzyme markers to Aspergillus nidulans chromosomes, using chromosome-substituted segregants of a hybrid of $A$. nidulans and $A$. quadrilineatus. Current Genetics, v.25, p.311-317, 1994.

VARNAM, A. H.; SUTHERLAND, J. P. Beverages: Technology, chemistry and microbiology. 3.ed. London: Chapman \& Hall, 1994. 464p.

VINE, R. P. Applications of technology in wine production. In: GUMP, B. H. Beer and wine production; analysis, characterization and technologycal advances. Washington: American Chemical Society, 1993. cap.8, p.132-49.

VEZINHET, F.; BLONDIN, B.; BARRE, P. Mapping of the FLO5 gene of Saccharoymyces cerevisiae by transfer of a chromossome during cytoduction. Biotechnology Letters, v.13, n.1, p.47-52, 1991. 
VEZINHET, F.; BLONDIN, B.; HALLET, J-N. Chromosomal DNA patterns and mitochondrial DNA polymorphism as tools for identification of enological strains of Saccharomyces cerevisiae. Applied Microbiology and Biotechnology, v.32, p.568-571, 1990.

VLUGT-BERGMANS, C. J. B. van der; BRANDWAGT, B. F.; KLOOSTER, J. W. van't; WAGEMAKERS, C. A. M.; KAN, J. A. L. van. Genetic variation and segregation of DNA polymorphims in Botrytis cinerea. Mycological Research, v.97, n.10, p.1193-1200, 1993.

VOGT, E. Fabricación de vinos. Zaragoza: Acribia, 1972. 292 p.

VOS, P. J. A.; GRAY, R. S. The origin and control of hydrogen sulfide during fermentation of grape must. American Journal of Enology and Viticulture, v.30, n.3, p.187-197, 1979.

WAINWRIGHT, T. Hydrogen sulphide production by yeasts under conditions of methionine, pantothenate or vitamin $\mathrm{B}_{6}$ deficiency. Journal of General Microbiology, v.61, n.1, p.107-110, 1970.

WAINWRIGHT, T. Poduction of $\mathrm{H}_{2} \mathrm{~S}$ by yeasts: role of nutrients. Journal of Applied Bacteriology, v.34, n.1, p.161-171, 1971.

WATSON, D. C. Yeasts in distilled alcoholic-beverage production. In: ROSE, A. H.; HARRISON, J. S. (Ed.) The Yeasts: Yeast technology. London: Academic Press, 1993. v.5, cap.6, p.215-244.

WELSH, J.; McCLELLAND, M. Fingerprinting genomes using PCR with arbitrary primers. Nucleic Acids Research, v.18, p.7213-7218, 1990. 
WHELAN, W. L.; MAGEE, P. T. Natural heterozygosity in Candida albicans. Journal of Bacteriology, v.145, p.896-903, 1981.

WILKIE, D. \& EVANS, I. Mitochondria and the yeast cell surface: implications for carcinogenesis. Trends in Biochemical Sciences, v.7, n.4, p.147-151, 1982.

WILLIAMS, J. G. K.; KUBELIK, A. R.; LIVAK, K. J.; RAFALSKI, J. A.; TINGEY, S. V. DNA polimorphisms amplified by arbitrary primers are useful as genetics markers. Nucleic Acids Research, v.18, p.6531-6535, 1990.

YAMASHITA, I. \& FUKUI, S. Mating signals control expression of both starch fermentation genes and a novel flocculation gene FLO8 in the yeast Saccharomyces. Agricultural and Biological Chemistry, v.47, n.12, p.2889-2896, 1983.

ZAMBONELLI, C. Ricerche biometriche sulla produzione de idrogeno solforato da solfati e solfiti in Saccharomyces cerevisiae var. ellipsoideus. Annali Microbiologia, v.14, p.129-141, 1964a.

ZAMBONELLI, C. Ricerche genetiche sulla produzione de idrogeno solforato in Saccharomyces cerevisiae var. ellipsoideus. Annali Microbiologia, v.14, p.143$53,1964 b$.

ZAMBONELLI, C. Ricerche genetiche sulla produzione de idrogeno solforato in Saccharomyces cerevisiae var. ellipsoideus. II. Ereditarietà del carattere dal punto di vista quantitativo. Annali Microbiologia, v.15, p.89-106, 1965.

ZAMBONELLI, C.; MUTINELLI, P.; PACCHETTI, G. Biosynthesis of sulphur amino acids in Saccharomyces cerevisiae I. Genetic analysis of leaky mutants of sulphite reductase. Archives of Microbiology, v.102, p.247-251, 1975. 